Prepared in cooperation with the Arkansas Natural Resources Commission

\title{
Mean Annual, Seasonal, and Monthly Precipitation and Runoff in Arkansas, 1951-2011
}

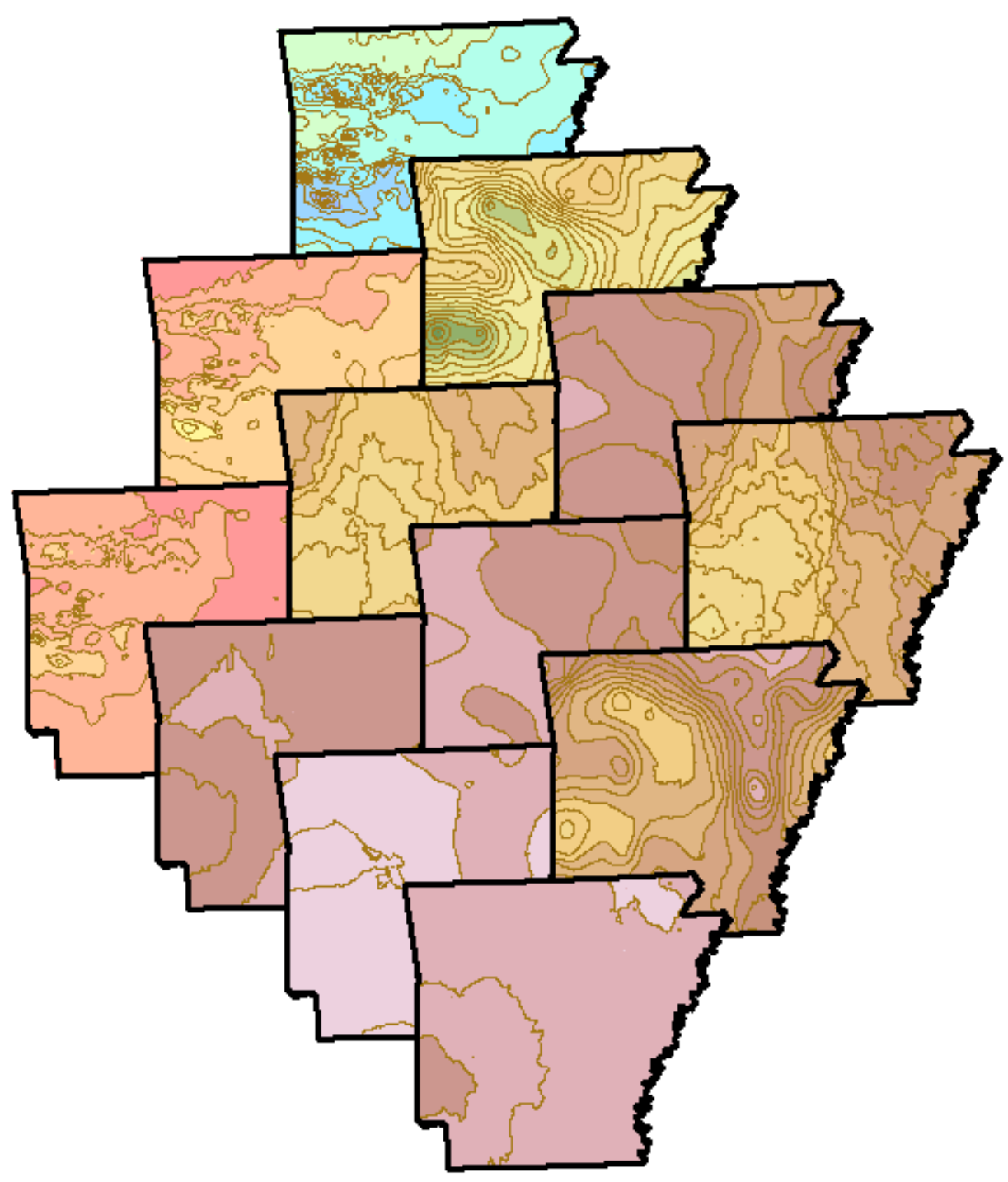

Scientific Investigations Report 2014-5006 



\section{Mean Annual, Seasonal, and Monthly Precipitation and Runoff in Arkansas, 1951-2011}

By Aaron L. Pugh and Drew A. Westerman

Prepared in cooperation with the Arkansas Natural Resources Commission

Scientific Investigations Report 2014-5006 


\section{U.S. Department of the Interior \\ SALLY JEWELL, Secretary}

\section{U.S. Geological Survey \\ Suzette M. Kimball, Acting Director}

\section{U.S. Geological Survey, Reston, Virginia: 2014}

For more information on the USGS — the Federal source for science about the Earth, its natural and living resources, natural hazards, and the environment, visit http://www.usgs.gov or call 1-888-ASK-USGS.

For an overview of USGS information products, including maps, imagery, and publications, visit http://www.usgs.gov/pubprod

To order this and other USGS information products, visit http://store.usgs.gov

Any use of trade, firm, or product names is for descriptive purposes only and does not imply endorsement by the U.S. Government.

Although this information product, for the most part, is in the public domain, it also may contain copyrighted materials as noted in the text. Permission to reproduce copyrighted items must be secured from the copyright owner.

Suggested citation:

Pugh, A.L., and Westerman, D.A., 2014, Mean annual, seasonal, and monthly precipitation and runoff in Arkansas, 1951-2011: U.S. Geological Survey Scientific Investigations Report 2014-5006, 40 p., http://dx.doi.org/10.3133/ sir20145006.

ISSN 2328-0328 (online) 


\section{Contents}

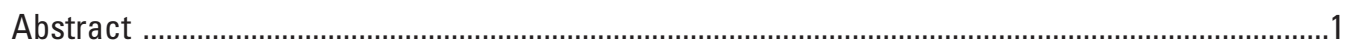

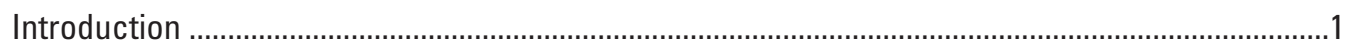

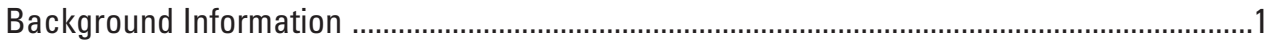

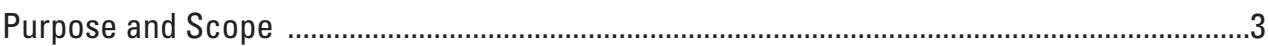

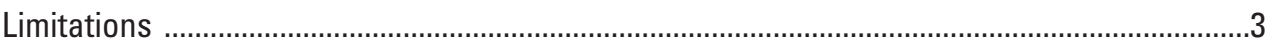

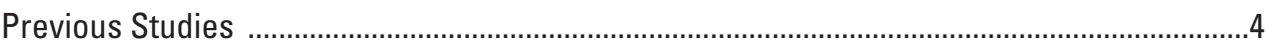

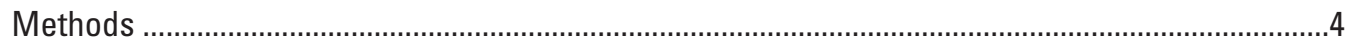

Determination of Wet and Dry Seasons …………………...................................................

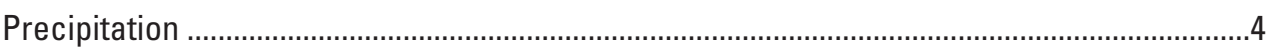

Selection of Continuous-Record Streamflow-Gaging Stations ...............................................

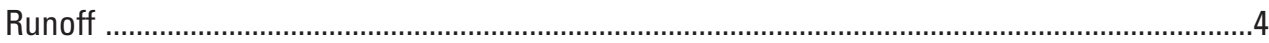

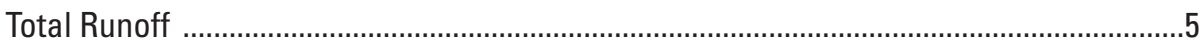

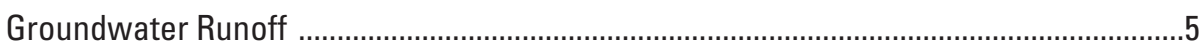

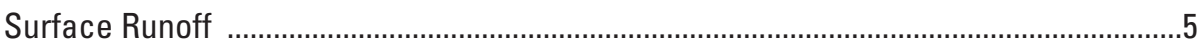

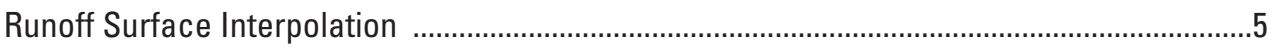

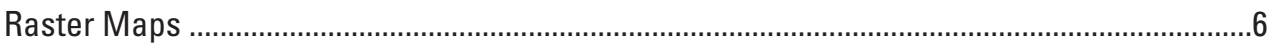

Annual, Seasonal, and Monthly Mean Precipitation ..................................................................

Mean Annual, Seasonal, and Monthly Runoff ..........................................................................

Mean Annual, Seasonal, and Monthly Total Runoff ............................................................10

Mean Annual, Seasonal, and Monthly Groundwater Runoff ..................................................14

Mean Annual, Seasonal, and Monthly Surface Runoff ..........................................................18

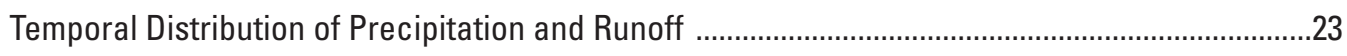

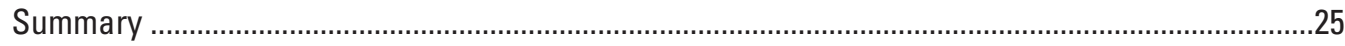

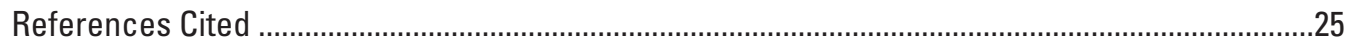

Appendixes (available online only)

1. Mean annual, monthly, and seasonal precipitation and runoff for Arkansas (1951-2011) XLS

2. GIS raster and contour shape files of mean annual and seasonal precipitation and runoff for Arkansas (1951-2011)

3. Google Earth KML of mean annual and seasonal precipitation and runoff for Arkansas (1951-2011)

\section{Figures}

1. Map showing locations of selected continuous-record streamflow-gaging stations and physiographic sections in Arkansas and sourrounding States ...................2

2. Map showing mean annual precipitation in Arkansas, 1951-2011 ..................................7

3. Map showing map showing mean wet season precipitation in Arkansas,

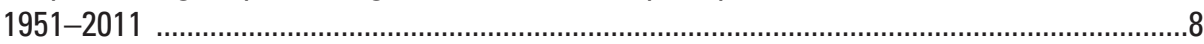

4. Map showing map showing mean dry season precipitation in Arkansas,

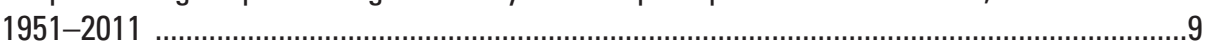

5. Map showing mean annual total runoff in Arkansas, 1951-2011 ....................................11

6. Map showing map showing mean wet season total runoff in Arkansas, 1951-2011 
7. Map showing map showing mean dry season total runoff in Arkansas, 1951-2011

8. Map showing mean annual groundwater runoff in Arkansas, 1951-2011

9. Map showing mean wet season groundwater runoff in Arkansas, 1951-2011 .............16

10. Map showing mean dry season groundwater runoff in Arkansas, 1951-2011 ..............17

11. Map showing mean annual surface runoff in Arkansas, 1951-2011 .............................19

12. Map showing map showing mean wet season surface runoff in Arkansas, 1951-2011

13. Map showing map showing mean dry season surface runoff in Arkansas, 1951-2011

14. Map showing maps showing mean annual and mean seasonal precipitation

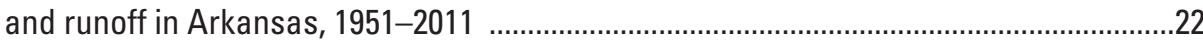

15. Graph of mean monthly precipitation and runoff for Arkansas, 1951-2011 ...................23

16. Graphs of mean monthly precipitation and runoff for physiographic sections in Arkansas, 1951-2011

\section{Tables}

1. Selected continuous-streamflow gaging stations analyzed for runoff within Arkansas and surrounding States

2. Estimated precipitation and runoff values for selected continuous-record streamflow-gaging stations within Arkansas and surrounding States

3. Annual and seasonal statistics for precipitation and runoff by physiographic sections in Arkansas, 1951-2011

4. Mean annual and monthly precipitation and runoff by physiographic sections in Arkansas, 1951-2011

5. Percentage of mean annual precipitation and runoff by month for physiographic sections in Arkansas, 1951-2011 


\section{Conversion Factors}

\begin{tabular}{lcl} 
Inch/Pound to SI & & \\
\hline \multicolumn{1}{c}{ Multiply } & By & \multicolumn{1}{c}{ To obtain } \\
\hline inch (in) & Length & centimeter $(\mathrm{cm})$ \\
foot $(\mathrm{ft})$ & 2.54 & meter $(\mathrm{m})$ \\
mile $(\mathrm{mi})$ & 0.3048 & kilometer $(\mathrm{km})$ \\
\hline & 1.609 & \\
\hline square foot $\left(\mathrm{ft}^{2}\right)$ & Area & square meter $\left(\mathrm{m}^{2}\right)$ \\
square mile $\left(\mathrm{mi}^{2}\right)$ & 0.09290 & hectare $($ ha) \\
square mile $\left(\mathrm{mi}^{2}\right)$ & 259.0 & square kilometer $\left(\mathrm{km}^{2}\right)$ \\
\hline & 2.590 & \\
\hline cubic foot $\left(\mathrm{ft}^{3}\right)$ & Volume & cubic meter $\left(\mathrm{m}^{3}\right)$ \\
\hline & 0.02832 & cubic meter per second $\left(\mathrm{m}^{3} / \mathrm{s}\right)$ \\
\hline cubic foot per second $\left(\mathrm{ft}^{3} / \mathrm{s}\right)$ & Flow rate & \\
\hline
\end{tabular}

Horizontal coordinate information is referenced to the North American Datum of 1983 (NAD 83).

Altitude, as used in this report, refers to distance above the North American Vertical Datum of 1988 (NAVD 88). 



\title{
Mean Annual, Seasonal, and Monthly Precipitation and Runoff in Arkansas, 1951-2011
}

\author{
By Aaron L. Pugh and Drew A. Westerman
}

\section{Abstract}

This report describes long-term annual, seasonal, and monthly means for precipitation and runoff in Arkansas for the period from 1951 through 2011. Precipitation means were estimated using data from the Parameter-elevation Regressions on Independent Slopes Model database; while total runoff, groundwater runoff, and surface runoff means were estimated using data from 123 active and inactive U.S. Geological Survey continuous-record streamflow-gaging stations located in Arkansas and surrounding States. Annual precipitation in Arkansas for the period from 1951 through 2011 had a mean of 49.8 inches. Of the six physiographic sections in Arkansas, the Ouachita Mountains had the largest mean annual precipitation at 53.0 inches, while the Springfield-Salem plateaus had the smallest mean annual precipitation at 45.5 inches. The mean annual total runoff for Arkansas was 17.8 inches. The Ouachita Mountains had the largest mean annual total runoff at 20.4 inches, while the Springfield-Salem plateaus had the smallest mean annual total runoff at 15.0 inches. Runoff is diminished during the dry season, which is attributed to increased losses from evapotranspiration, consumptive uses including irrigation, and increased withdrawals for public and private water supplies. The decline in runoff during the dry season is observed across the State in all physiographic sections. Spatial results for precipitation and runoff are presented in a series of maps that are available for download from the publication Web page in georeferenced raster formats.

\section{Introduction}

Water is an important resource that is normally plentiful in Arkansas. Hydrologic studies undertaken to define the occurrence and availability of freshwater aid in the planning and management of this important resource. Annual precipitation and runoff represent the upper limit of water potentially available for development and, consequently, form the base for many hydrologic investigations. Therefore, a study to reevaluate long-term mean annual, seasonal, and monthly precipitation and runoff in Arkansas was needed and is one of several studies completed by the U.S. Geological Survey (USGS) in cooperation with the Arkansas Natural Resources Commission (ANRC). These studies were conducted to update and increase the basic knowledge of hydrologic and hydraulic properties of Arkansas' surfacewater and groundwater resources and are part of ANRC's efforts to update the Arkansas State Water Plan.

\section{Background Information}

Runoff is the volume of water in a stream resulting from precipitation, snowmelt, or irrigation flowing from the drainage basin over a specific period of time. Runoff measured at the drainage-basin outlet is the net streamflow of the stream, including both contributions from groundwater discharge (hereafter termed groundwater runoff) and surface or overland flow (hereafter termed surface runoff) (Langbein and Iseri, 1960) to the stream with losses occurring from evapotranspiration, groundwater recharge, and consumptive uses. Runoff can be expressed by a variety of numerical variables, but average depth of water over the drainage basin, in inches (in.), is the most commonly used unit of measurement and was used for this report.

Runoff is directly affected by climate, land use, vegetation, geology, soil type, elevation, slope, topography, drainage network patterns, lakes, and reservoirs. Many of these physical characteristics have been classified spatially into physiographic regions, which provide a convenient methodology for examining runoff. Fenneman (1946) developed a broad-scale, three-tiered classification for the United States that organizes similar regions into divisions, provinces, and sections.

Arkansas contains parts of six physiographic sections including the Springfield-Salem plateaus, the Boston Mountains, the Arkansas Valley, the Ouachita Mountains, the Mississippi Alluvial Plain, and the West Gulf Coastal Plain (fig. 1). The Springfield-Salem plateaus and the Boston Mountains are dissected areas with steep valley walls and narrow valley floors. The Springfield-Salem plateaus are underlain by southward-dipping Ordovician through Pennsylvanian limestone and dolostone. Sinkholes, springs, and caves are common in the limestone of the 

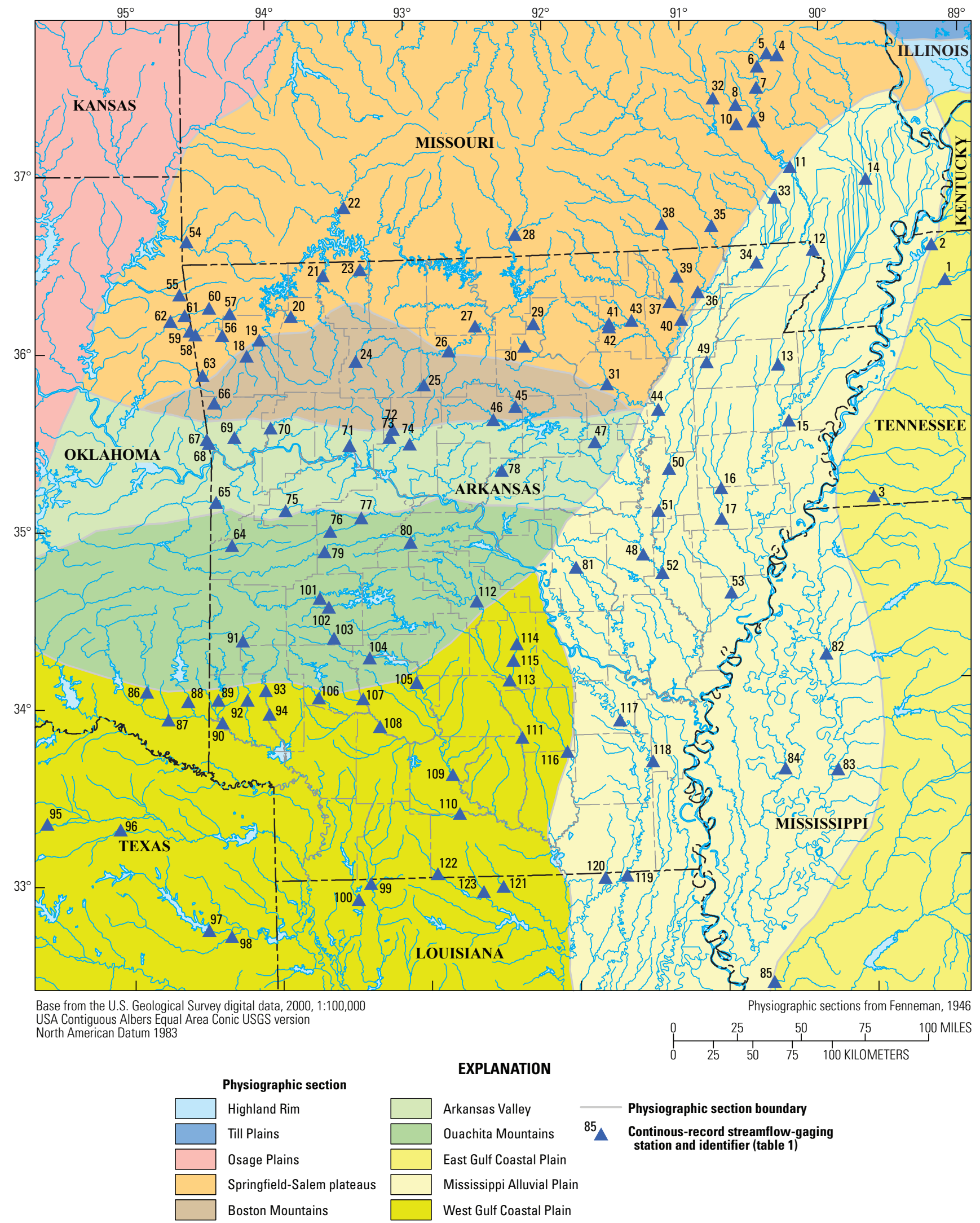

station and identifier (table 1)

Figure 1. Locations of selected continuous-record streamflow-gaging stations and physiographic sections in Arkansas and sourrounding States. 
Springfield-Salem plateaus with less karst development in the dolostone. The Boston Mountains are underlain by Pennsylvanian sandstone and shale deposited by south/ southwestward flowing streams during times of low sea level. The Arkansas Valley is a low-lying region surrounding the Arkansas River and its valley. Parts of the section include mountain ridges that rise above the lowlands, separated by broad valleys. The surficial geology in the Arkansas Valley consists of a sequence of coal-bearing, weathered, Pennsylvanian sandstone and shale overlain by Quaternary alluvial sediments along the Arkansas River. The Ouachita Mountains consist of a mostly east-west trending series of sharp ridges, which are often buckled and distorted, separated by narrow to broad valleys underlain by Ordovician through Pennsylvanian shale, sandstone, novaculite, chert, and minor limestone. The Mississippi Alluvial Plain is a relatively level plain containing mostly unconsolidated alluvial sediments of gravel, sand, silt, clay, and loess. The West Gulf Coastal Plain is a south-sloping plain of gently rolling hills. The northwestern part of the West Gulf Coastal Plain in Arkansas is underlain by Cretaceous gravel, sand, clay, marl, and limestone; the remaining part is underlain by Tertiary clay, sand, and silt with lignite deposits and Quaternary gravel, sand, and clay (Arkansas Geological Survey, 2013).

\section{Purpose and Scope}

The purpose of this report is to describe the results of a study of long-term mean annual, seasonal, and monthly precipitation and runoff in Arkansas for the period from 1951 through 2011 and describe the factors related to precipitation and runoff variability. The results of the study are presented in a series of maps depicting mean annual and seasonal precipitation, total runoff, groundwater runoff, and surface runoff, which were prepared by using a geostatistical interpolation model, and graphs of mean monthly precipitation and runoff.

\section{Limitations}

Typically, runoff maps are constructed by contouring runoff values calculated from data at specific locations, such as streamflow-gaging stations. Simple contouring of runoff point data does not account for the spatial variability in the factors that affect runoff including climate, land use, vegetation, geology, soil type, elevation, slope, topography, drainage network patterns, lakes, and reservoirs. Ideally, regional runoff equations would be developed that incorporate all of these factors. The development of regional equations is time consuming, expensive, and beyond the scope of this report. To improve on the traditional contouring method, a geostatistical interpolation model (esri, 2010) was used to produce the runoff raster maps presented in this report.
Interpolated data provide a continuous grid of cells across an area of interest with each cell representing an individual and unique data value. Data interpolation models make predications from known data and produce a continuous grid of new values for all locations including those with known data. Different interpolation models are governed by different sets of equations; accordingly, one model will represent the data better than another. Ideally, the interpolated grid would be generated from evenly spaced, high-quality point data that represent the potential spatial variability. However, this rarely is the case and sometimes the data can be overrepresented in populated areas and be sparse in others. For example, Daly and others (2008) noted the precipitation data might not match well against the point data level, but value comparisons were similar when data were averaged over larger areas. This aspect can be related to all the interpolated grids provided as part of this report.

The accuracy of runoff estimates depends on the period of record used for the analysis. Records for a station operated during a period of extreme climatological conditions, such as mostly wet or mostly dry years, exhibit a bias toward the extreme. A long-term station with a record representative of long-term climatological conditions provides a more reliable runoff estimate because extremes have less weight in the determination of runoff characteristics.

Groundwater runoff estimates were made using base-flow index (BFI) (Wahl and Wahl, 1988, 1995) values calculated from USGS continuous-record streamflow-gaging station data. Because the flow data were not parsed by month or season before BFI values were determined, the user should consider annual groundwater runoff estimates more reliable than monthly or seasonal estimates.

Total runoff estimates, and in turn, groundwater and surface runoff estimates for the Mississippi Alluvial Plain section should be used judiciously. Runoff estimates are affected by anthropogenic influences such as stream regulation, effluent discharge, and groundwater depletion, which change the natural flow of a stream. Streams within the Mississippi Alluvial Plain have been hydrologically altered (channelized, impounded, and diverted) to suit agricultural purposes (Justus, 2003). Also, analysis of the Mississippi embayment aquifer system groundwater budget by the Mississippi Embayment Regional Aquifer Study (MERAS) indicated changes in groundwater storage have occurred. The study suggested that, as of about 1986, the Mississippi embayment aquifer system is no longer providing groundwater runoff to the streams, but that the streams are providing recharge to the aquifer system (Clark and others, 2011). Furthermore, it appears the substantial number of large reservoirs in the upper watersheds of the White and Black Rivers have created a ridge of artificial elevated runoff values in the lower parts of these watersheds located in the Mississippi Alluvial Plain. Because this study examined long-term means (1951-2011), recent changes in hydrologic conditions are not well represented in the results presented. 


\section{Previous Studies}

Mean annual precipitation and mean annual runoff data for Arkansas are in need of reevaluation. The last known statewide study of average annual precipitation and average annual runoff (Freiwald, 1984) was completed 30 years ago and was compiled for the period 1951 through 1980. Hedman and others (1987) developed precipitation and runoff maps of the Ozark region, which included parts of northern Arkansas. Patterson (1971) included a small precipitation map of Arkansas that only included data through 1958 in a flood study report. Moix and Galloway (2004) characterized base flow (groundwater runoff), waterquality, and stream gain and loss in the Buffalo River Basin in north-central Arkansas for the period of July and August 2003. Langbein (1949), Busby (1966), and Gebert and others (1987) developed runoff maps for the whole United States. Wolock (2003a, 2003b) published geospatial raster digital data sets for a base-flow index grid (Wolock, 2003a) and for estimated mean annual natural groundwater recharge (Wolock, 2003b) for the conterminous United States.

\section{Methods}

The following sections describe the methods used to estimate mean annual, seasonal, and monthly precipitation and runoff in Arkansas for the period 1951-2011. These include the method used to determine the wet and dry seasons, how precipitation estimates were derived, the selection of continuous-record streamflow-gaging stations, how runoff estimates (including total runoff, groundwater runoff, and surface runoff) were derived, and how runoff surfaces were interpolated.

\section{Determination of Wet and Dry Seasons}

Wet and dry seasons were determined by using the Independent-Samples t-Test on the mean monthly total runoff data (see the Runoff section of the report). The Independent-

Samples t-Test compares means for two groups and evaluates whether the means for two groups are significantly different from each other (Dowdy and Wearden, 1983). The monthly mean total runoff data were divided into two groups, wet season $\left(\mu_{\mathrm{w}}\right)$ and dry season $\left(\mu_{\mathrm{D}}\right)$, and tested using the null hypothesis $\left(\mathrm{H}_{0}\right): \mu_{\mathrm{w}}=\mu_{\mathrm{D}}$, and the alternative hypothesis $\left(\mathrm{H}_{1}\right): \mu_{\mathrm{w}} \neq \mu_{\mathrm{D}}$, at a 95 -percent confidence level $(\alpha=0.05)$. The test was repeated with the monthly data being divided into different groupings of wet and dry seasons. Grouping the months of December through May into the wet season and June through November into the dry season produced results having a significant difference between wet season and dry season with the largest $t$ value and the smallest pooled variance.

\section{Precipitation}

The precipitation data used for this study were derived from the Parameter-elevation Regressions on Independent Slopes Model (PRISM; PRISM Climate Group, 2013), which is spatially gridded and available on a monthly and annual time step for the period of interest. PRISM data include the interpolation of point data from precipitation monitoring stations, the pattern and effects of mountainous terrain, and other climatic parameters influencing precipitation in the development of a continuous grid for the United States (PRISM Climate Group, 2013). The precipitation data were distributed across Arkansas at a cell size resolution of approximately 2.5 miles (mi) on a side. Annual and seasonal values were produced by summing the appropriate monthly grids.

\section{Selection of Continuous-Record Streamflow- Gaging Stations}

Runoff values in this report were estimated from data collected at 123 active and inactive USGS continuous-record streamflow-gaging stations located in Arkansas and surrounding States (fig. 1, table 1 at end of report). Continuous-record streamflow-gaging stations record continuous stream stage (gage height) from which daily, monthly, and annual mean streamflow were computed. Annual, seasonal, and monthly runoff values were estimated from annual daily mean and monthly mean discharge values from continuous-record streamflow-gaging stations with 20 or more years of data for the period from 1951 through 2011 (U.S. Geological Survey, 2013); a few stations with less than 20 years of record (table 1) were included to provide data in areas where no data were otherwise available. Some continuous-record streamflow-gaging stations were eliminated from the study because they were located downstream from large reservoirs or springs, which adversely affected runoff estimates. To improve interpolation near the State borders, gaging stations located outside of Arkansas also were chosen. Of the 123 continuous-record streamflow-gaging stations chosen, 81 were from Arkansas, 7 from northern Louisiana, 4 from western Mississippi, 16 from southern Missouri, 8 from eastern Oklahoma, 3 from western Tennessee, and 4 from northeastern Texas (fig. 1, table 1).

\section{Runoff}

Means for total runoff, groundwater runoff, and surface runoff were estimated on an annual, seasonal, and monthly basis for the 123 active and inactive USGS continuous-record streamflow-gaging stations. Annual total runoff estimates for each gaging station were made using annual daily mean discharge data (U.S. Geological Survey, 2013), while seasonal and monthly total runoff estimates were made using monthly mean discharge data (U.S. Geological Survey, 2013). Annual, seasonal, and monthly groundwater runoff estimates were made by multiplying the annual, seasonal, and monthly total 
runoff estimates for each gaging station by the BFI values associated with each gaging station. Annual, seasonal, and monthly surface runoff estimates for each gaging station were made by subtracting the groundwater runoff estimate from the total runoff estimate. These data were plotted geographically and interpolated using a geostatistical method to produce the runoff map figures presented in this report.

\section{Total Runoff}

Mean annual total runoff was estimated using annual daily mean discharge data (U.S. Geological Survey, 2013) from selected USGS continuous-record streamflow-gaging stations. The annual mean daily flow estimates were converted to total annual flow and divided by the drainage area to determine the annual total runoff. The annual total runoff estimates were summed and divided by the number of years of gaging record to determine the mean annual total runoff estimates (table 2 at end of report and appendix 1). (Appendix 1 is an Excel spreadsheet containing location information, drainage areas, PRISM precipitation estimates, and annual, monthly, and seasonal runoff estimates for each USGS continuous-record streamflow-gaging station analyzed. Appendix 1 is available online only at http://pubs.usgs.gov/ sir/2014/5006/.

The total mean runoff estimates for the wet and dry seasons were determined using monthly mean discharge data (U.S. Geological Survey, 2013) from selected USGS continuous-record streamflow-gaging stations for each year of the gaging record. The wet season was defined by grouping data from the months of December through May, while the dry season was defined by grouping data from the months of June through November. The monthly mean discharge data were multiplied by the number of days in the month to determine the total monthly mean flow and divided by the drainage area to determine the monthly mean runoff. The monthly mean runoff values for the months in the wet and dry seasons, respectively, were summed and divided by the number of years of gaging record to determine the mean wet and dry season total runoff (table 2 and appendix 1).

\section{Groundwater Runoff}

Mean groundwater runoff is the portion of the total runoff from seepage of water from the ground into a stream channel. Groundwater runoff is estimated by multiplying the total runoff by the BFI. The BFI is the ratio of groundwater runoff to total runoff, expressed as a percentage. A BFI reference grid for the conterminous United States based on point estimates from analysis of USGS continuous-record streamflow-gaging station data was first published in 2003 by Wolock (2003a). Wolock has maintained this BFI database and provided this study with average BFI values for the streamflow-gaging stations used for analysis (D.M. Wolock, U.S. Geological Survey, written commun., 2013) (table 2 and appendix 1). Wolock computed BFI values using an automated hydrograph separation computer program called the BFI program (Wahl and Wahl, 1988, 1995). Additional information on the BFI program is available on the BFI Web page at http://www.usbr. gov/pmts/hydraulics_lab/twahl/bfi/index.html.

\section{Surface Runoff}

Surface runoff is that part of the total runoff that travels over the land surface to the nearest stream channel or that part of the total runoff of a drainage basin that has not passed beneath the land surface since precipitation. Surface runoff was estimated by subtracting the groundwater runoff from the total runoff (table 2 and appendix 1).

\section{Runoff Surface Interpolation}

Five different surface interpolation models were tested to determine which model produced the most accurate surfaces for the mean annual runoff point data. Surface interpolation models create a continuous raster surface from input point values by computing a value for each raster cell on the continuous surface. It was important to use a model that can maximize the ability to match known data points and also have a strong predictive ability by accounting for variability. Interpolation models are generally divided into deterministic and geostatistical methods. Four deterministic interpolation models were tested: the Inverse Distance Weighted (IDW) model; the Natural Neighbor (NN) model; the Spline model; and the Topo to Raster (Topo) model. Kriging was the only geostatistical model tested (esri, 2010).

To test the accuracy of the different interpolation models, the original mean annual runoff dataset was divided into two parts. The first part, called the training set, was used to model a raster surface, and the second part, called the test set, was used to compare and validate the modeled raster surface. From the original 126 mean annual runoff data points, 11 points were randomly selected for the test dataset. The remaining 115 mean annual runoff data points were used for the training dataset. Using the training dataset, nine raster surfaces were interpolated using model default values, one each for IDW, $\mathrm{NN}$, and Topo, two for Spline (one using regularized default values and one using tension default values), and four Kriging (one using Simple Kriging default values, one using Universal Kriging with no transformation type default values, one using Universal Kriging with a Log Order transformation default values, and one using Universal Kriging with a Box-Cox transformation default values). From these nine raster surfaces, the cell value at each test site location was determined. The test site raster cell values were compared with the corresponding mean annual runoff values from the test set and the percent differences and absolute differences for each point were calculated. The raster surface developed using the Simple Kriging model provided the lowest mean percent difference (3.66 with a standard deviation $[\sigma]$ of 2.34) and the lowest mean absolute difference (6.31 with a $\sigma$ of 0.57 ). This same test methodology was used to determine 
what Simple Kriging input values produced the most accurate raster surface. The Simple Kriging model using 19 input data points within a spherical radius provided the lowest mean percent difference (3.23 with a $\sigma$ of 1.85) and the lowest mean absolute difference (5.58 with a $\sigma$ of 0.51$)$. The runoff maps in this report were developed from nine raster surfaces interpolated using the Simple Kriging model with 19 input data points within a spherical radius and with a cell size resolution of approximately $1.4 \mathrm{mi}$ on a side.

To quantify the accuracy of the Simple Kriging model used to generate the nine runoff maps, the root mean squared error (RMSE) was calculated for each model. The RMSE provides an indication of how closely a model predicts the measured value (esri, 2010). The smaller the RMSE value, the more closely the model prediction matches the measured values. The RMSE values for mean annual, wet season, and dry season total runoff were $0.70,2.21$, and 1.07 in., respectively. The RMSE values for mean annual, wet season, and dry season groundwater runoff were 1.38, 0.90, and 0.57 in., respectively. The RMSE values for mean annual, wet season, and dry season surface runoff were 1.47, 0.49, and 0.59 in., respectively. RMSE values were calculated using the following equation:

$$
R M S E=\sqrt{\frac{1}{n} \sum_{i=1}^{n}\left(p_{i}-r_{i}\right)^{2}}
$$

where

$$
\begin{gathered}
n \quad \text { is the number of paired predicted and } \\
\text { estimated values, }
\end{gathered}
$$

\section{Raster Maps}

Estimates for precipitation and runoff are presented in a series of 12 single map figures (figs. 2-13) and one multimap figure (fig. 14). These maps were created using PRISM raster data for precipitation and the raster estimates from the runoff interpolations for annual, wet season, and dry season runoff. The georeferenced raster and contour layers used to create these figures are available online in a geographic information system (GIS) raster format and a keyhole markup language (KML) compatible format (appendixes 2 and 3 available online only at http://pubs.usgs.gov/sir/2014/5006/).

\section{Annual, Seasonal, and Monthly Mean Precipitation}

Precipitation in Arkansas is normally abundant and well distributed throughout the year with the largest amounts occurring in the Ouachita Mountains section and the smallest amounts occurring in the Springfield-Salem plateaus section. The mean annual precipitation in Arkansas for the period from 1951 through 2011 was 49.8 in. (figs. 2 and 14, table 3 at end of report) with monthly means ranging from 3.0 in. occurring in August to 5.2 in. occurring in May (table 4 at end of report). Arkansas' mean wet season precipitation was $26.9 \mathrm{in}$., ranging from $20.6 \mathrm{in}$. at a location in the SpringfieldSalem plateaus section to $34.1 \mathrm{in}$. at a location in the Ouachita Mountains section (figs. 3 and 14, table 3). Arkansas' mean dry season precipitation was 22.9 in., ranging from 19.7 in. at a location in the Mississippi Alluvial Plain section to $31.2 \mathrm{in}$. at a location in the Ouachita Mountains section (figs. 4 and 14 , table 3).

The Ouachita Mountains section received the largest mean annual precipitation at $53.0 \mathrm{in}$. and the largest mean dry season precipitation at $24.9 \mathrm{in}$. (table 3 ). The minimum mean monthly precipitation in the Ouachita Mountains section was 3.0 in. occurring in August, while the maximum mean monthly precipitation was 5.7 in. occurring in May (table 4). The Ouachita Mountains section, and to lesser extent, the Boston Mountains section received larger amounts of precipitation because of the local orographic lifting of moisture moving over these sections and falling as precipitation (Foti, 2011; U.S. Department of Agriculture, 1971, 1975a, 1975b).

The Springfield-Salem plateaus section received the smallest mean annual precipitation at $45.5 \mathrm{in}$. and the smallest mean wet season precipitation at 23.2 in. (table 3). The minimum mean monthly precipitation in the SpringfieldSalem plateaus section was 2.7 in. occurring in January, while the maximum mean monthly precipitation was $5.0 \mathrm{in}$. occurring in May (table 4). The Springfield-Salem plateaus section, and to a lesser extent, the Arkansas Valley section received smaller amounts of precipitation because of local orographic lifting in the Boston and Ouachita Mountains, resulting in leeward rain shadows reducing precipitation in the Springfield-Salem plateaus and Arkansas Valley sections (Foti, 2011; U.S. Department of Agriculture, 1975a, 1975b).

The Mississippi Alluvial Plain section received an intermediate amount of mean annual precipitation at $49.9 \mathrm{in}$. but had the largest mean wet season precipitation at $28.3 \mathrm{in}$. and the smallest mean dry season precipitation at $21.6 \mathrm{in}$. (table 3). The minimum mean monthly precipitation in the Mississippi Alluvial Plain section was 2.9 in. occurring in August, while the maximum mean monthly precipitation was 5.1 in. occurring in April and May (table 4). Precipitation in the Mississippi Alluvial Plain during the wet season was associated with warm frontal systems or wintery low pressure systems approaching from the Southern Plains or the Gulf of Mexico and provided a reliable source of moisture, while sporadic single storm events provided less reliable precipitation during the dry season (U.S. Department of Agriculture, 1971, 1978). 


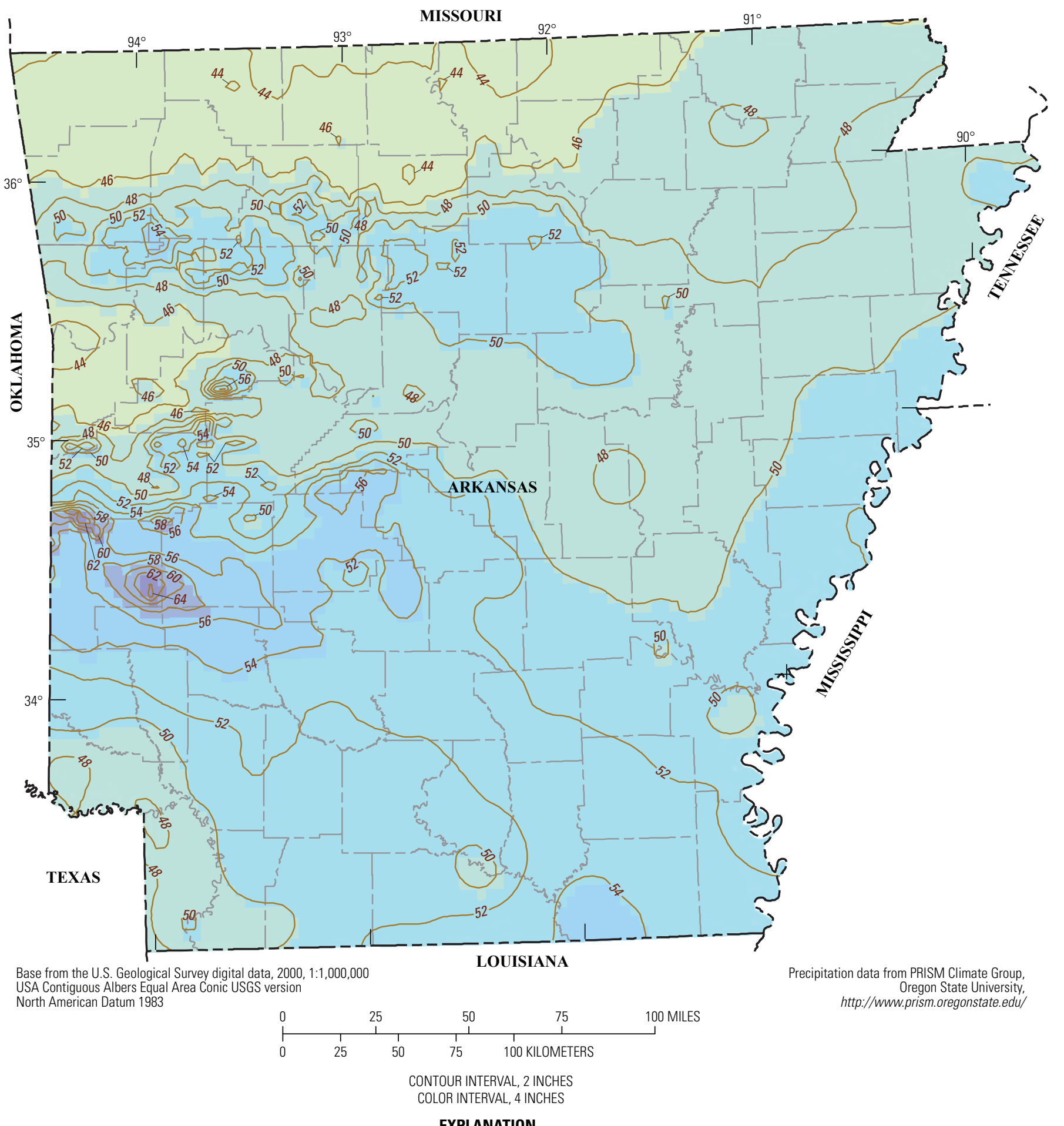

Mean annual precipitation, in inches

\begin{tabular}{|l|l|l|}
\hline & $42-46$ \\
$46-50$ & \\
& & \\
& & $54-58$ \\
& & $58-62$ \\
$62-66$
\end{tabular}

$-52-$ Line of equal mean annual precipitation in inches

Figure 2. Mean annual precipitation in Arkansas, 1951-2011. 


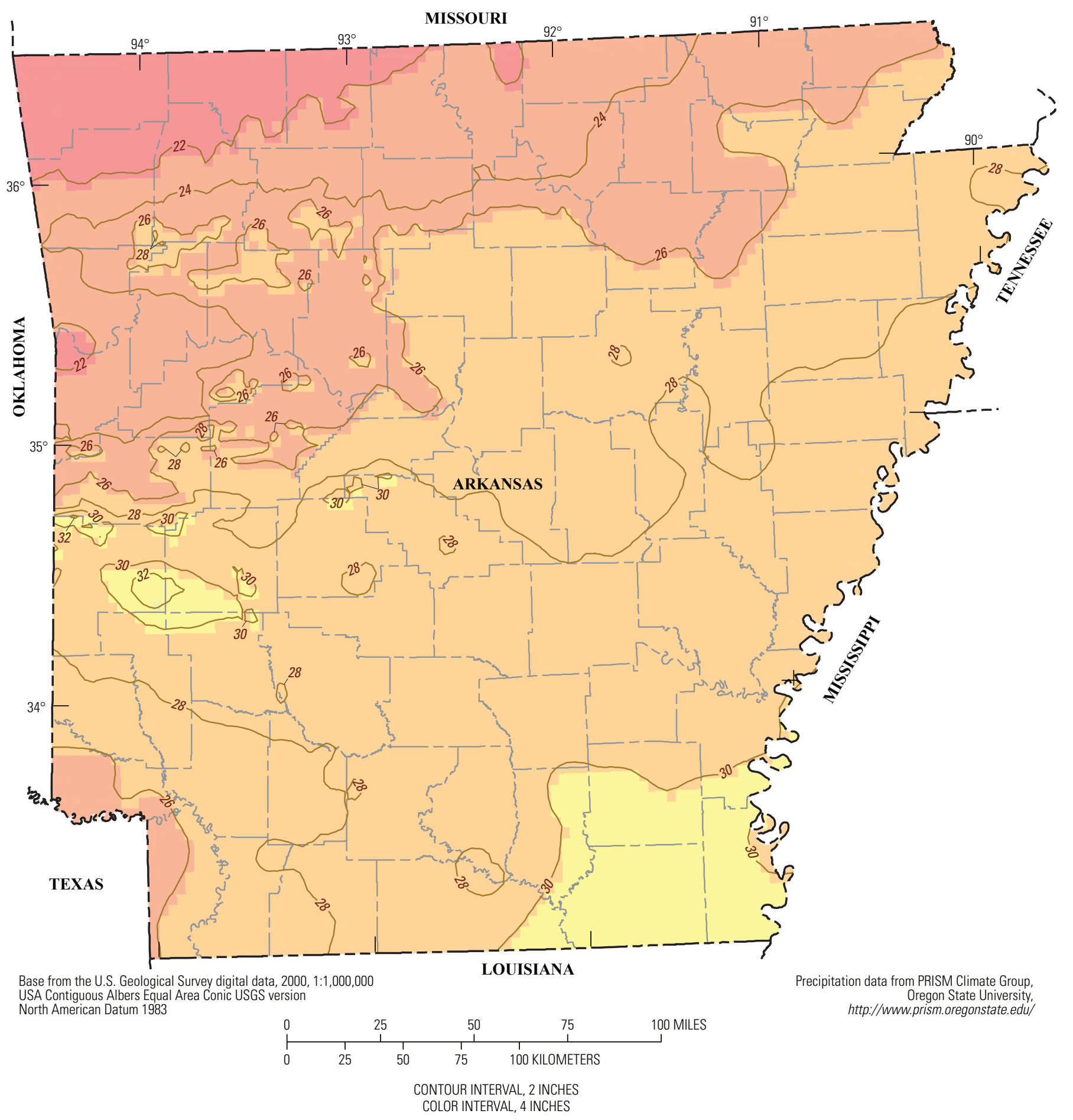

EXPLANATION

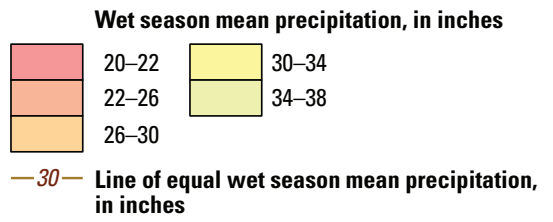

Figure 3. Map showing mean wet season precipitation in Arkansas, 1951-2011. 


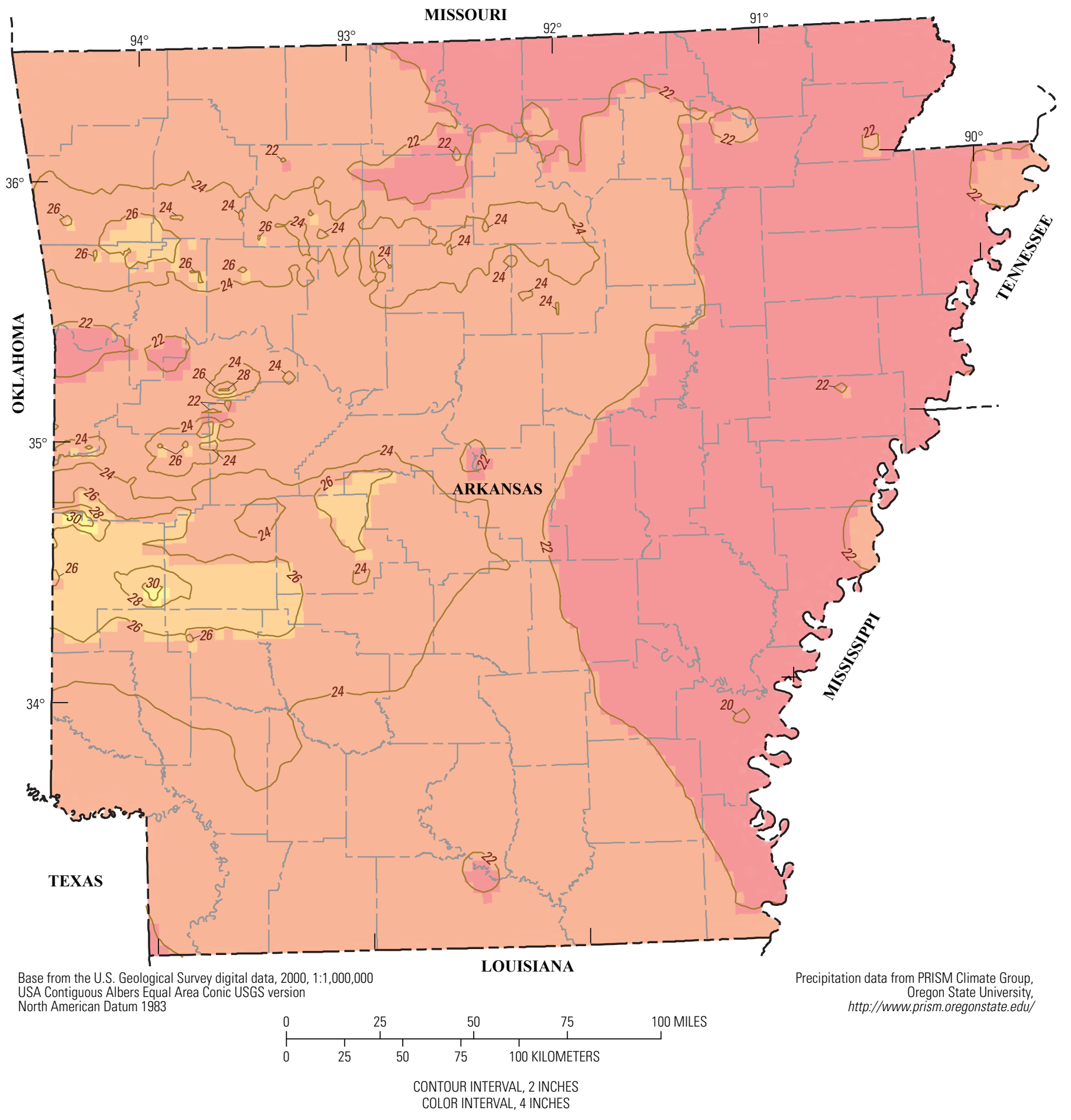

EXPLANATION

Dry season mean precipitation, in inches

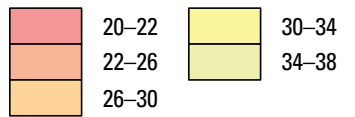

-22 - Line of equal dry season mean precipitation,

in inches

Figure 4. Map showing mean dry season precipitation in Arkansas, 1951-2011. 


\section{Mean Annual, Seasonal, and Monthly Runoff}

Runoff occurs chiefly as a residual of precipitation after demands for evapotranspiration, groundwater recharge, and consumptive uses have been supplied. Maximum runoff occurs during periods of intense precipitation on saturated soils when there is little time for losses from evapotranspiration, groundwater recharge, or consumptive uses to occur before the water enters a stream. Arkansas experiences a wide range of runoff resulting from local differences in climate, land use, vegetation, geology, soil type, elevation, slope, topography, drainage network patterns, lakes, and reservoirs.

\section{Mean Annual, Seasonal, and Monthly Total Runoff}

The mean annual, wet season, and dry season total runoff patterns for Arkansas generally reflect precipitation patterns while experiencing greater losses from increased evapotranspiration and consumptive uses during the dry season. The mean annual, wet season, and dry season total runoff for 1951-2011 in Arkansas was 17.8 in., 13.2 in., and 4.3 in., respectively (table 3 ). Statewide, the smallest mean monthly total runoff occurred in August, with a value of 0.4 in., while the largest mean monthly total runoff occurred in March and April, with values of 2.6 in. (table 4).

The Ouachita Mountains section experienced the largest mean annual total runoff at 20.4 in., the largest mean wet season total runoff at $14.8 \mathrm{in}$., and the largest mean dry season total runoff at 4.6 in. (figs. 5, 6, 7 and 14, table 3). The minimum mean monthly total runoff in the Ouachita Mountains section was 0.3 in., occurring in August, while the maximum mean monthly total runoff was 3.0 in., occurring in March (table 4). The larger mean total runoff values in the Ouachita Mountains section may be attributed to larger precipitation amounts, steeper gradients, and relatively impermeable surficial geology. Rapid runoff associated with these variables limits time available for evapotranspiration and groundwater recharge, increasing surface runoff and reducing total runoff losses.

The Springfield-Salem plateaus section experienced the smallest mean annual total runoff at $15.0 \mathrm{in}$. and the smallest mean wet season total runoff at 11.7 in. (figs. 5, 6, and 14, table 3). The minimum mean monthly total runoff in the Springfield-Salem plateaus section was 0.4 in., occurring in August, while the maximum mean monthly total runoff was 2.5 in., occurring in April (table 4). The Springfield-Salem plateaus section consists of dissected karst, limestone and dolostone with relatively thin soils on steep slopes. The smaller mean total runoff values in the Springfield-Salem plateaus are the result of smaller precipitation amounts and the rapid infiltration through the thin soils and into the underlying karst limestone and dolostone.

The Boston Mountains and Arkansas Valley sections are different topographically and geologically, but through different mechanisms, both yield the smallest mean dry season total runoff of 4.1 in. (figs. 7 and 14, table 3). The minimum mean monthly total runoff in the Boston Mountains and Arkansas Valley sections was 0.3 in., occurring in August, while the maximum mean monthly total runoff was 2.8 in., occurring in April in the Boston Mountains and in March and April in the Arkansas Valley (table 4). The Boston Mountains section contains a large percentage of forested areas, which intercept and quickly take up precipitation resulting in large runoff losses from evapotranspiration. The Arkansas Valley consists of gently undulating, low topography underlain by weathered limestone and sandstone. The combination of low slopes and weathered bedrock produces larger runoff losses to evapotranspiration and groundwater recharge resulting in smaller total runoff in the Arkansas Valley. 


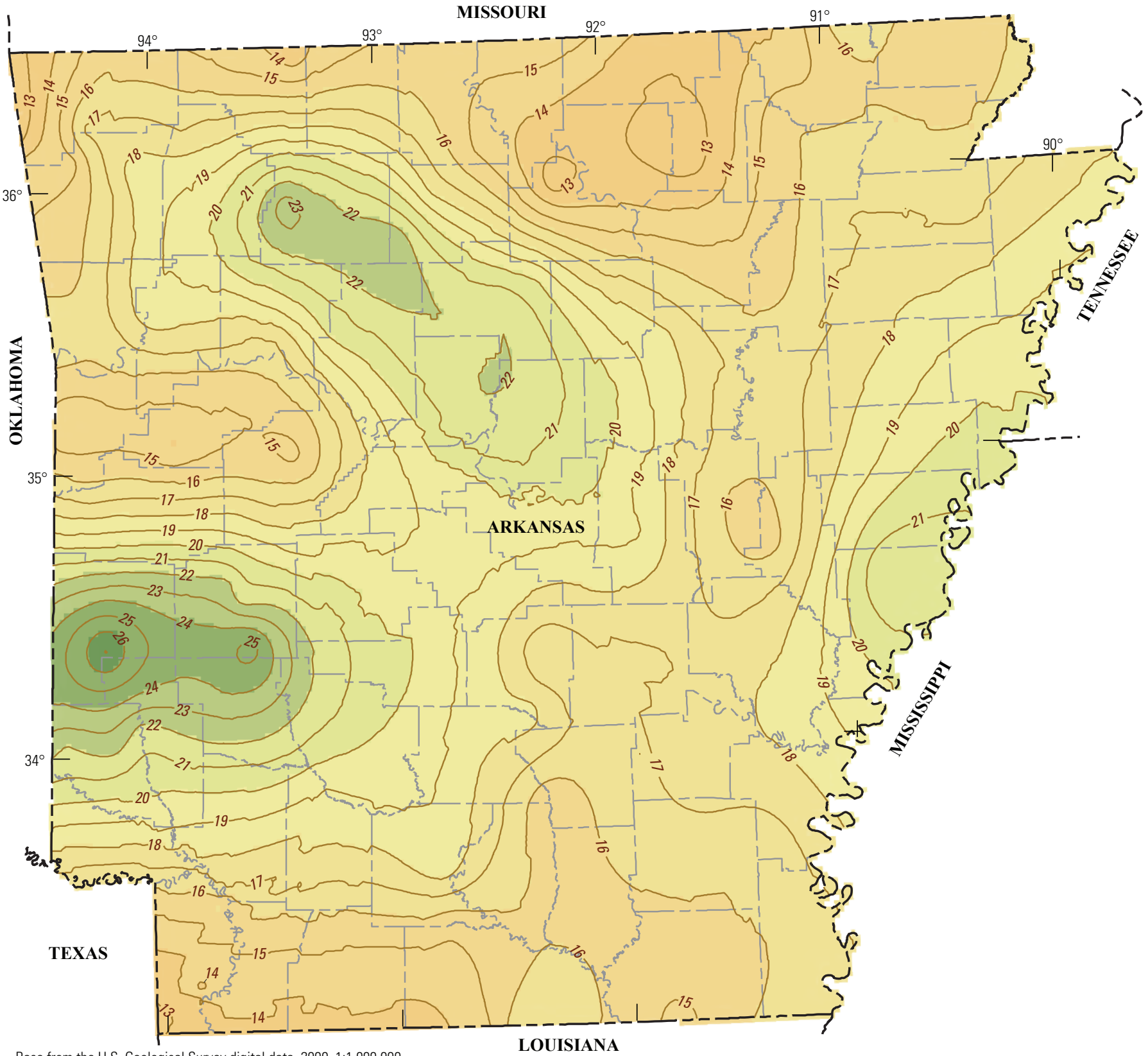

Base from the U.S. Geological Survey digital data, 2000, 1:1,000,000 USA Contiguous Albers Equal Area Conic USGS version North American Datum 1983

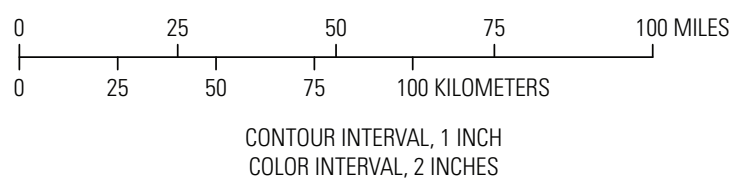

EXPLANATION

Mean annual total runoff, in inches

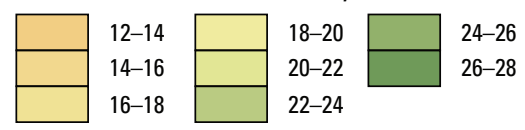

-15- Line of equal mean annual runoff, in inches-Root mean squared error is 0.70 inch

Figure 5. Mean annual total runoff in Arkansas, 1951-2011. 


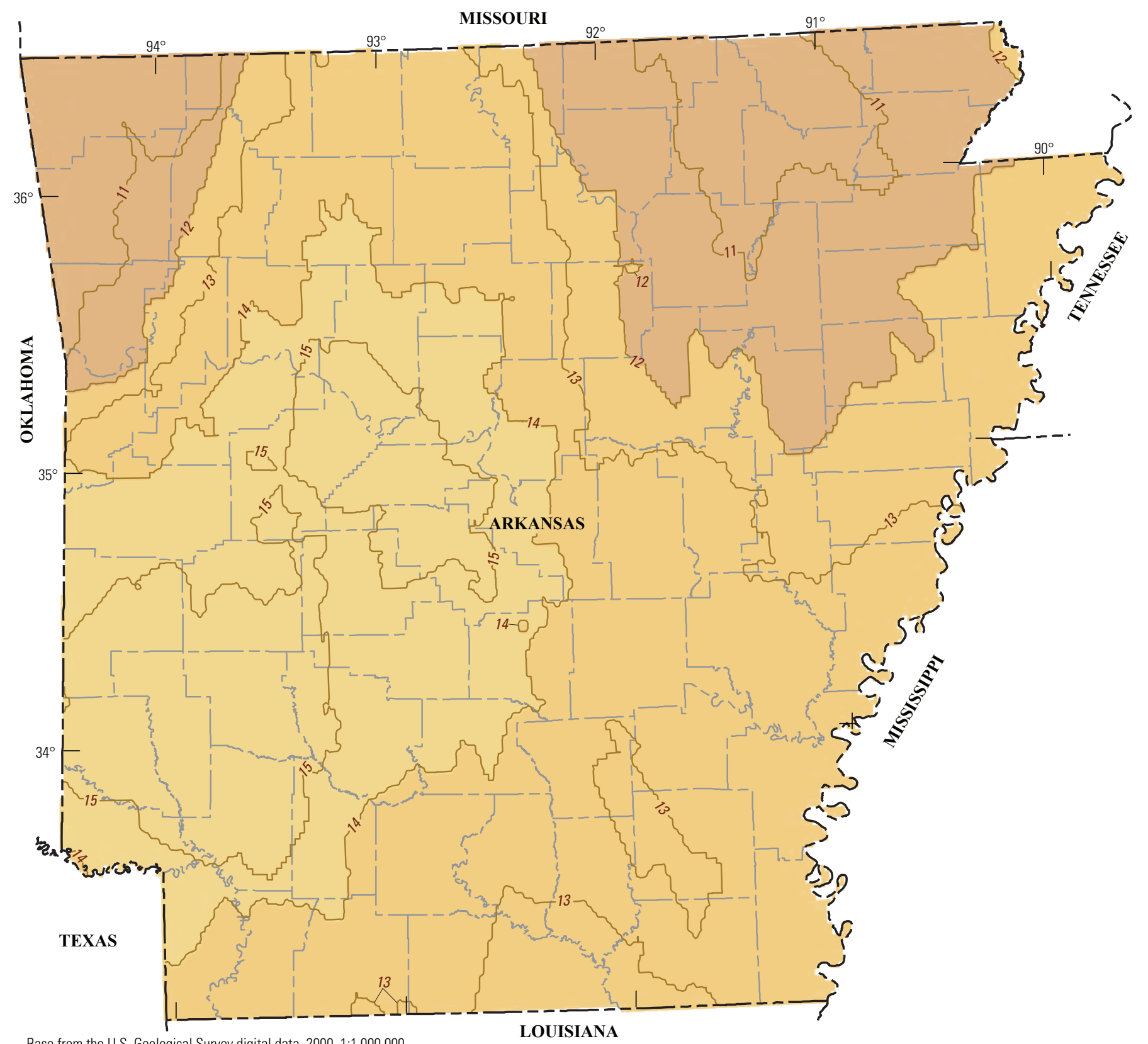

Base from the U.S. Geological Survey digital data, 2000, 1:1,000,000 USA Contiguous Albers Equal Area Conic USGS version North American Datum 1983

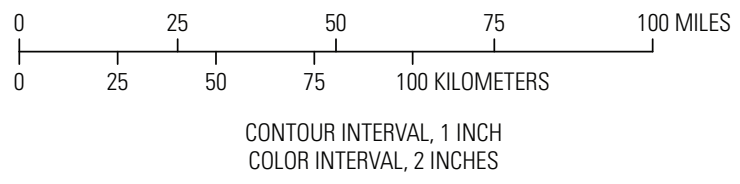

\section{EXPLANATION}

Mean wet season total runoff, in inches

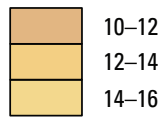

$-13-$ Line of equal mean wet season total runoff,
in inches-Root mean squared error is 2.21

Figure 6. Map showing mean wet season total runoff in Arkansas, 1951-2011. 


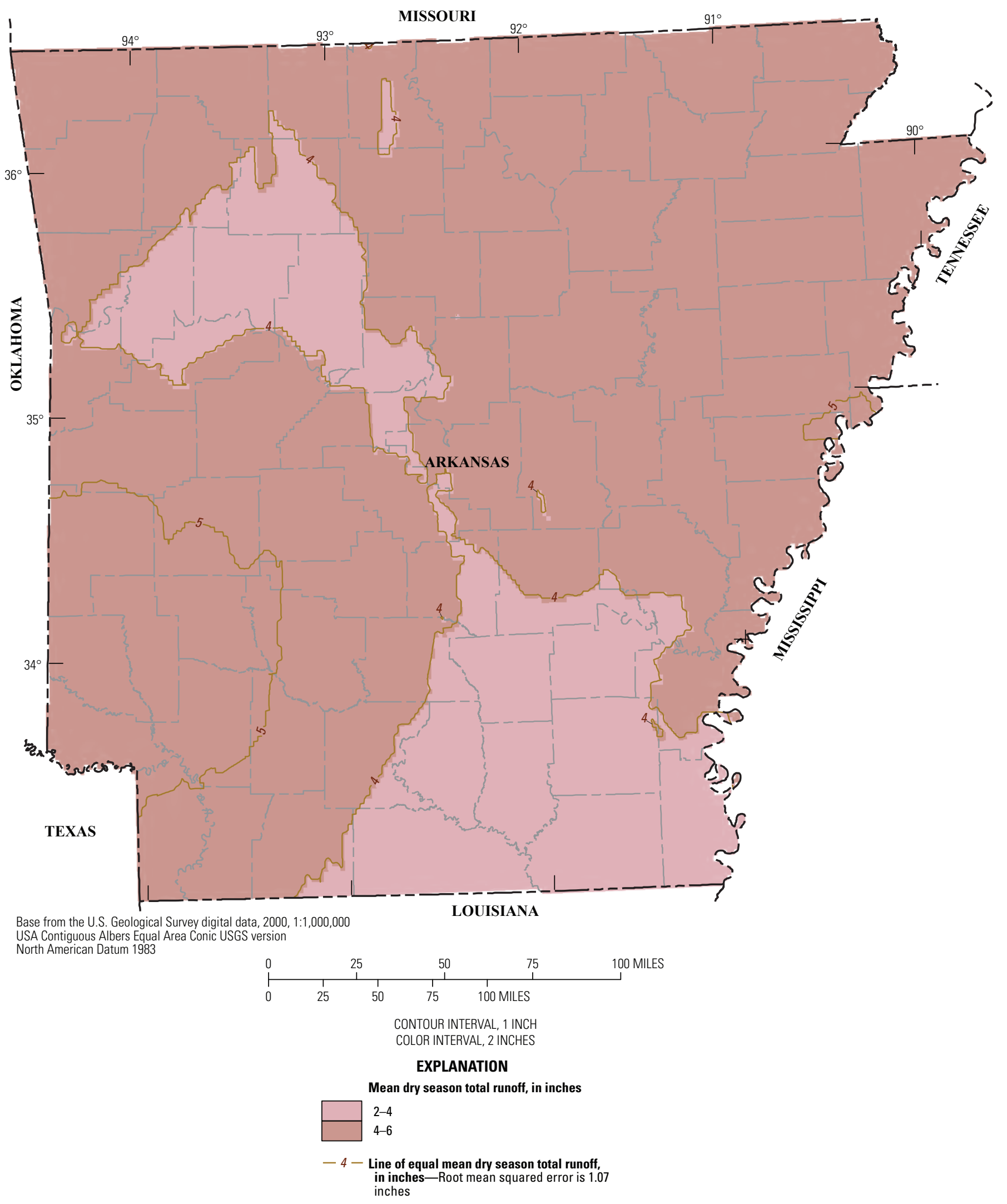

Figure 7. Map showing mean dry season total runoff in Arkansas, 1951-2011. 


\section{Mean Annual, Seasonal, and Monthly Groundwater Runoff}

The mean annual, wet season, and dry season groundwater runoff in Arkansas are generally equal to approximately one-third of the mean annual, wet season, and dry season total runoff, and thus, follow the same general patterns. The mean annual, wet season, and dry season groundwater runoff for 1951-2011 in Arkansas was 6.1 in., 4.5 in., and 1.6 in., respectively (table 3). Statewide, the smallest mean monthly groundwater runoff occurred in July, August, September, and October with a value of 0.2 in., while the largest mean monthly groundwater runoff occurred in March and April with a value of 0.9 in. (table 4).

The Mississippi Alluvial Plain section experienced the largest mean annual groundwater runoff at 7.5 in., the largest mean wet season groundwater runoff at 5.6 in., and one of the largest mean dry season groundwater runoffs at 2.0 in. (figs. 8, 9, 10 and 14, table 3). The minimum mean monthly groundwater runoff was 0.2 in., occurring in September, while the maximum mean monthly groundwater runoff was 1.1 in., occurring in March (table 4). The Mississippi Alluvial Plain section overlies the Mississippi embayment aquifer system. Analysis from the MERAS model of the groundwaterflow budget suggests that through approximately 1986, the Mississippi embayment aquifer system lost slightly more water to overlying streams then was recharged back into the aquifer system. After 1986, the study suggests the Mississippi embayment aquifer system received slightly more water from overlying streams than was lost (Clark and others, 2011). The uppermost hydrogeologic unit of the Mississippi embayment aquifer system is the Mississippi River Valley alluvial aquifer.
Recent studies of the Mississippi River Valley alluvial aquifer potentiometric surface indicate groundwater flow is away from the major rivers within the Mississippi Alluvial Plain section, suggesting these rivers are losing water to recharge the underlying Mississippi River Valley alluvial aquifer (Schrader, 2008, 2010). Because runoff values listed in this report are 61 year means, these more recent changes in the surfacegroundwater interactions are not reflected in the results. Readers are cautioned to consider this stipulation before using the Mississippi Alluvial Plain groundwater runoff data.

The Springfield-Salem plateaus section also experienced the largest mean dry season groundwater runoff at $2.0 \mathrm{in}$. (figs. 10 and 14, table 3). The minimum mean monthly groundwater runoff in the Springfield-Salem plateaus was 0.2 in., occurring in August, while the maximum mean monthly groundwater runoff was 1.0 in., occurring in March and April (table 4). The Springfield-Salem plateaus are underlain by karstified limestone and dolostone, which releases water from groundwater storage to the streams producing larger dry season groundwater recharge values.

The Ouachita Mountains section experienced the smallest mean annual groundwater runoff at 4.9 in., the smallest mean wet season groundwater runoff at 3.7 in., and one of the smallest mean dry season groundwater runoffs at 1.2 in. (figs. 8, 9, 10 and 14, table 3). The minimum mean monthly groundwater runoff in the Ouachita Mountains section was 0.1 in., occurring in August and September, while the maximum mean monthly groundwater runoff was 0.8 in., occurring in March (table 4). The Ouachita Mountains section is underlain by relatively impermeable surficial geology resulting in little groundwater storage available to provide groundwater recharge to the streams. 


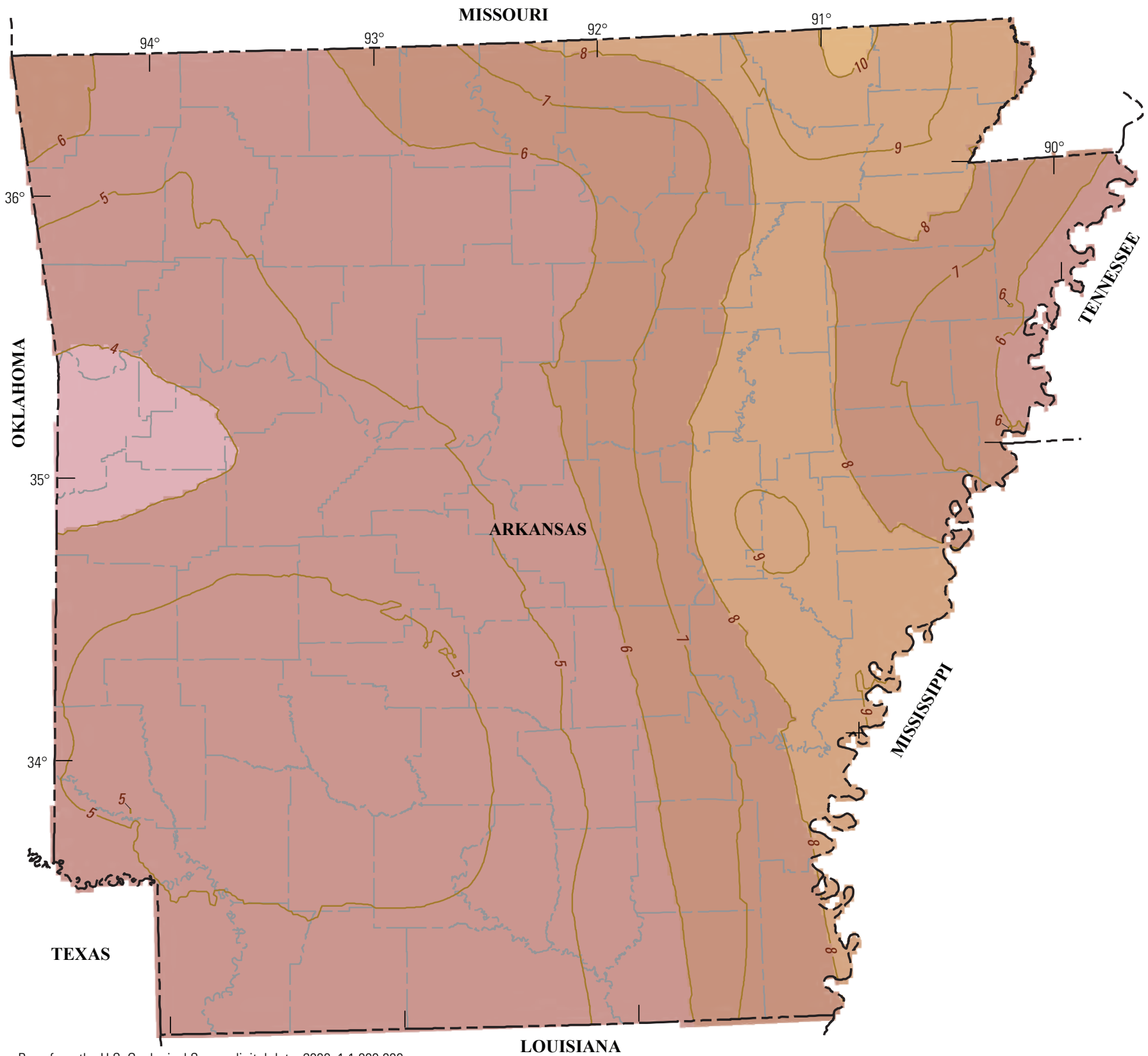

Base from the U.S. Geological Survey digital data, 2000, 1:1,000,000 USA Contiguous Albers Equal Area Conic USGS version

North American Datum 1983

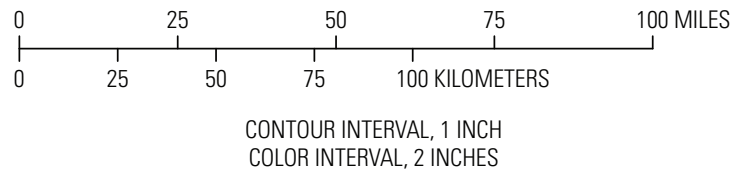

\section{EXPLANATION}

Mean annual groundwater runoff, in inches

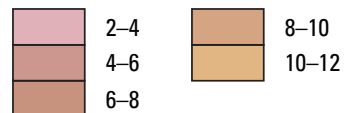

$-5-$ Line of equal mean annual groundwater runoff, in inches-Root mean squared error is 1.38 inches

Figure 8. Mean annual groundwater runoff in Arkansas, 1951-2011. 


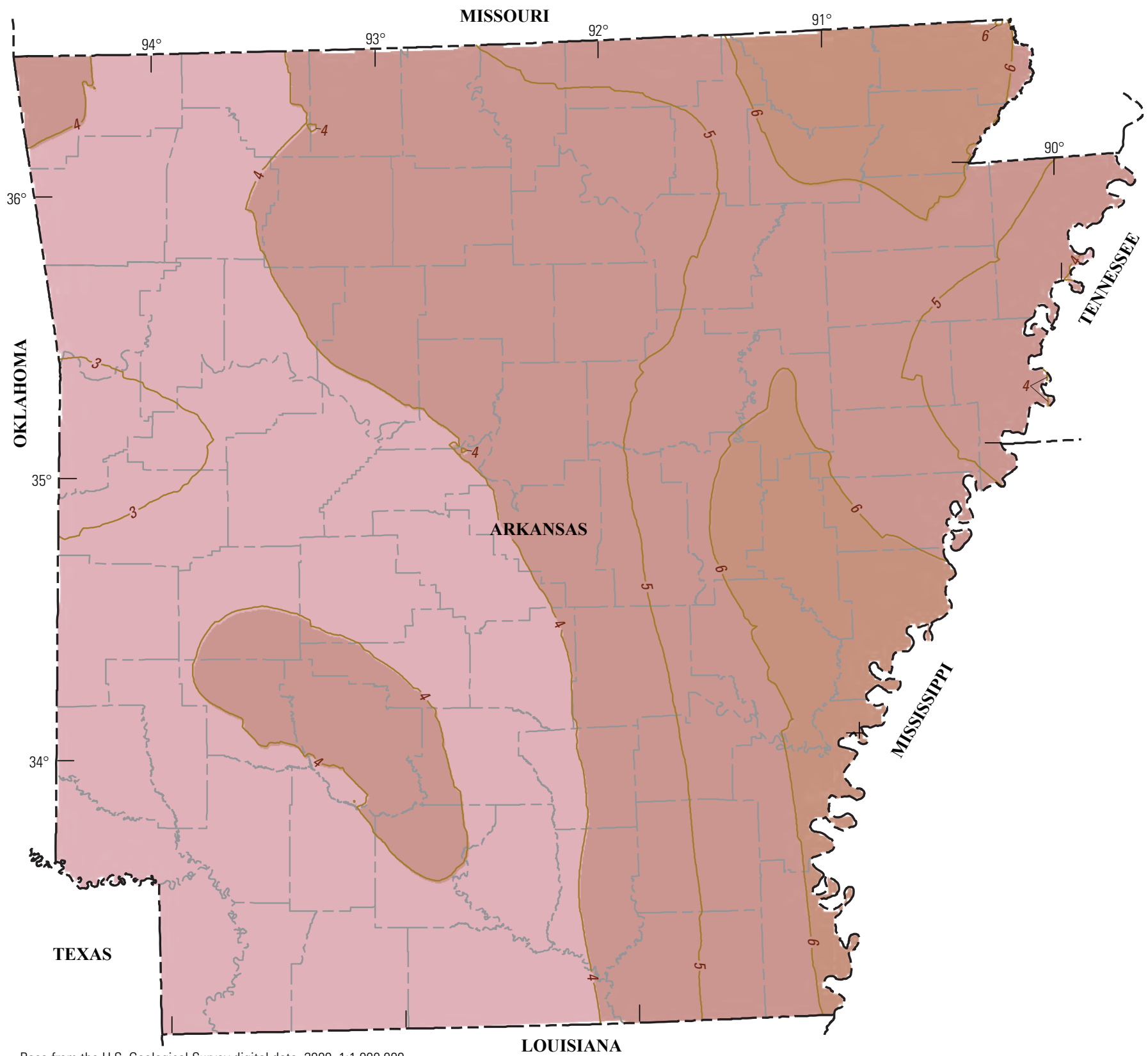

Base from the U.S. Geological Survey digital data, 2000, 1:1,000,000 USA Contiguous Albers Equal Area Conic USGS version North American Datum 1983

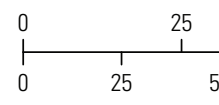

CONTOUR INTERVAL, 1 INCH

COLOR INTERVAL, 2 INCHES

\section{EXPLANATION}

Mean wet season groundwater runoff, in inches

$0-2$

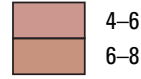

$-4-$ Line of equal mean wet season groundwater runoff,

in inches-Root mean squared error is 0.90 inch

Figure 9. Mean wet season groundwater runoff in Arkansas, 1951-2011. 


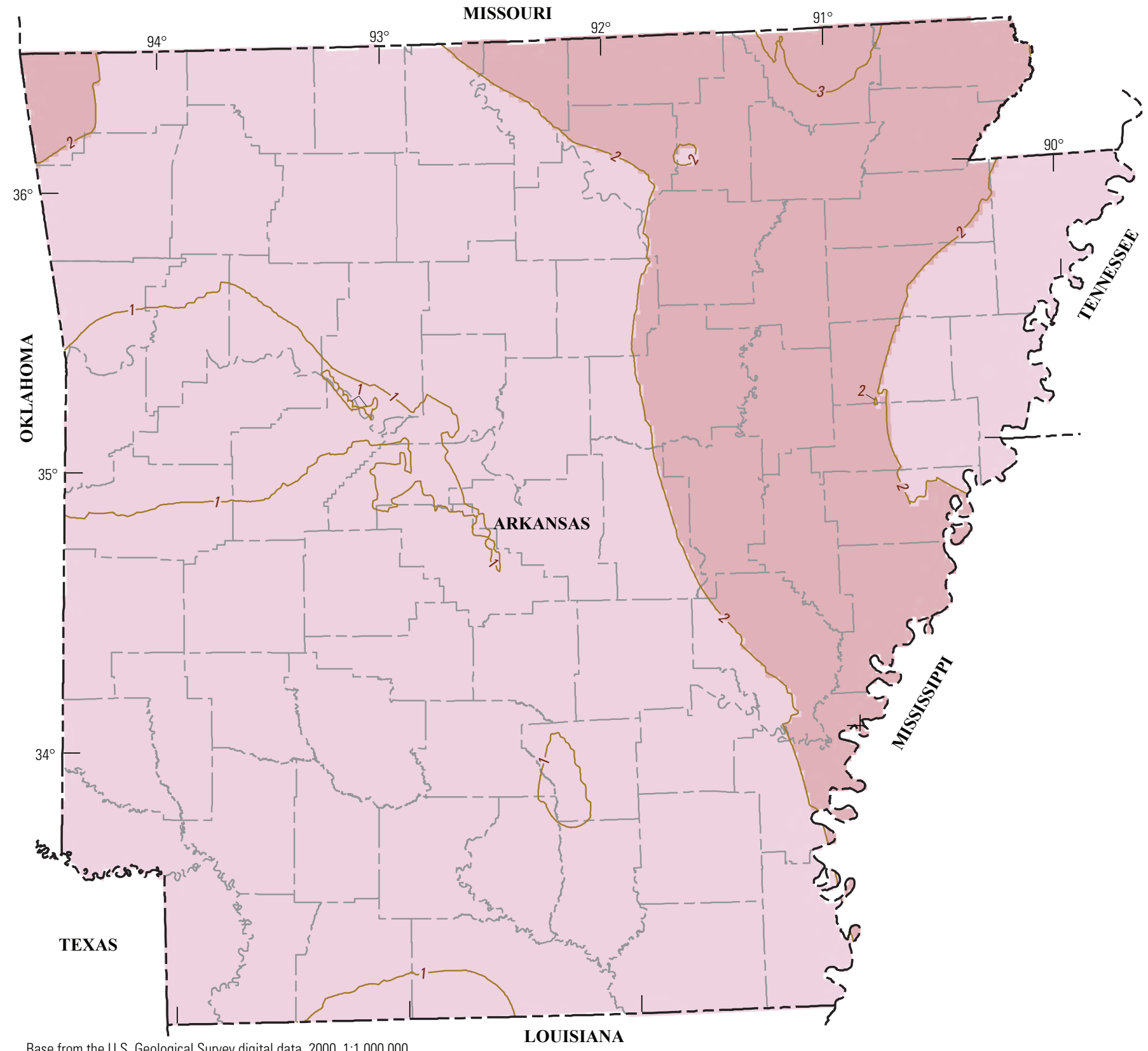

Base from the U.S. Geological Survey digital data, 2000, 1:1,000,000 USA Contiguous Albers Equal Area Conic USGS version North American Datum 1983

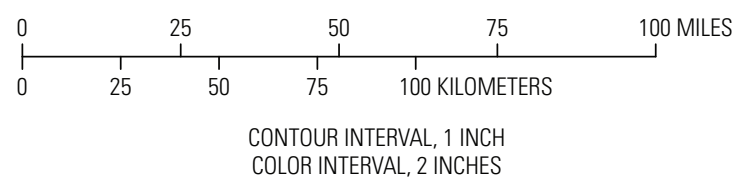

EXPLANATION

Mean dry season groundwater runoff, in inches

$0-2$

$2-4$

$-4-$ Line of equal mean dry season groundwater

runoff, in inches-Root mean squared

error is 0.57 inch

Figure 10. Mean dry season groundwater runoff in Arkansas, 1951-2011. 


\section{Mean Annual, Seasonal, and Monthly Surface Runoff}

The mean annual, wet season, and dry season surface runoff in Arkansas are generally equal to approximately twothirds of the mean annual, wet season, and dry season total runoff, and thus, follow the same general patterns. The mean annual, wet season, and dry season surface runoff for 19512011 in Arkansas was 11.4 in., 8.8 in., and 2.7 in., respectively (table 3). Statewide, the smallest mean monthly surface runoff occurred in August, with a value of 0.2 in., while the largest mean monthly surface runoff occurred in March, with a value of 1.8 in. (table 4 ).

The Ouachita Mountains section experienced the largest mean annual surface runoff at 14.5 in., the largest mean wet season surface runoff at 11.7 in., and the largest mean dry season surface runoff at 3.4 in. (figs. 11-14, table 3). The minimum mean monthly surface runoff in the Ouachita Mountains section was 0.2 in., occurring in August, while the maximum mean monthly surface runoff was 2.4 in., occurring in March (table 4). The larger mean surface runoff values in the Ouachita Mountains section may be attributed to larger precipitation amounts, steeper gradients, and relatively impermeable surficial geology. Rapid runoff associated with these variables limits time available for evapotranspiration and groundwater recharge, increasing surface runoff and reducing total runoff losses.
The Springfield-Salem plateaus section experienced the smallest mean annual surface runoff at 9.3 in., and the smallest mean wet season surface runoff at 5.7 in. (figs. 11, 12, and 14, table 3). The minimum mean monthly surface runoff in the Springfield-Salem plateaus section was 0.2 in., occurring in August, while the maximum mean monthly surface runoff was 1.5 in., occurring in April (table 4). The smaller surface runoff values occurred in the Springfield-Salem plateaus because the area receives smaller precipitation amounts and because the underling karst limestone and dolostone facilitate groundwater recharge.

The Mississippi Alluvial Plain section experienced the smallest mean dry season surface runoff at 2.3 in. (figs. 13-14, table 3). The minimum mean monthly surface runoff in the Mississippi Alluvial Plain section was 0.3 in., occurring in each of the four months of July, August, September, and October, while the maximum mean monthly surface runoff was 1.6 in., occurring in December (table 4). The Mississippi Alluvial Plain is a relatively level plain containing unconsolidated alluvial deposits capped by clay in many areas. The combination of low slopes and the impermeable clay cap produces large runoff losses to evapotranspiration, and in areas where the clay cap is missing, there are large runoff losses to groundwater recharge. Together these large runoff losses result in relatively small surface runoff values in the Mississippi Alluvial Plain. 


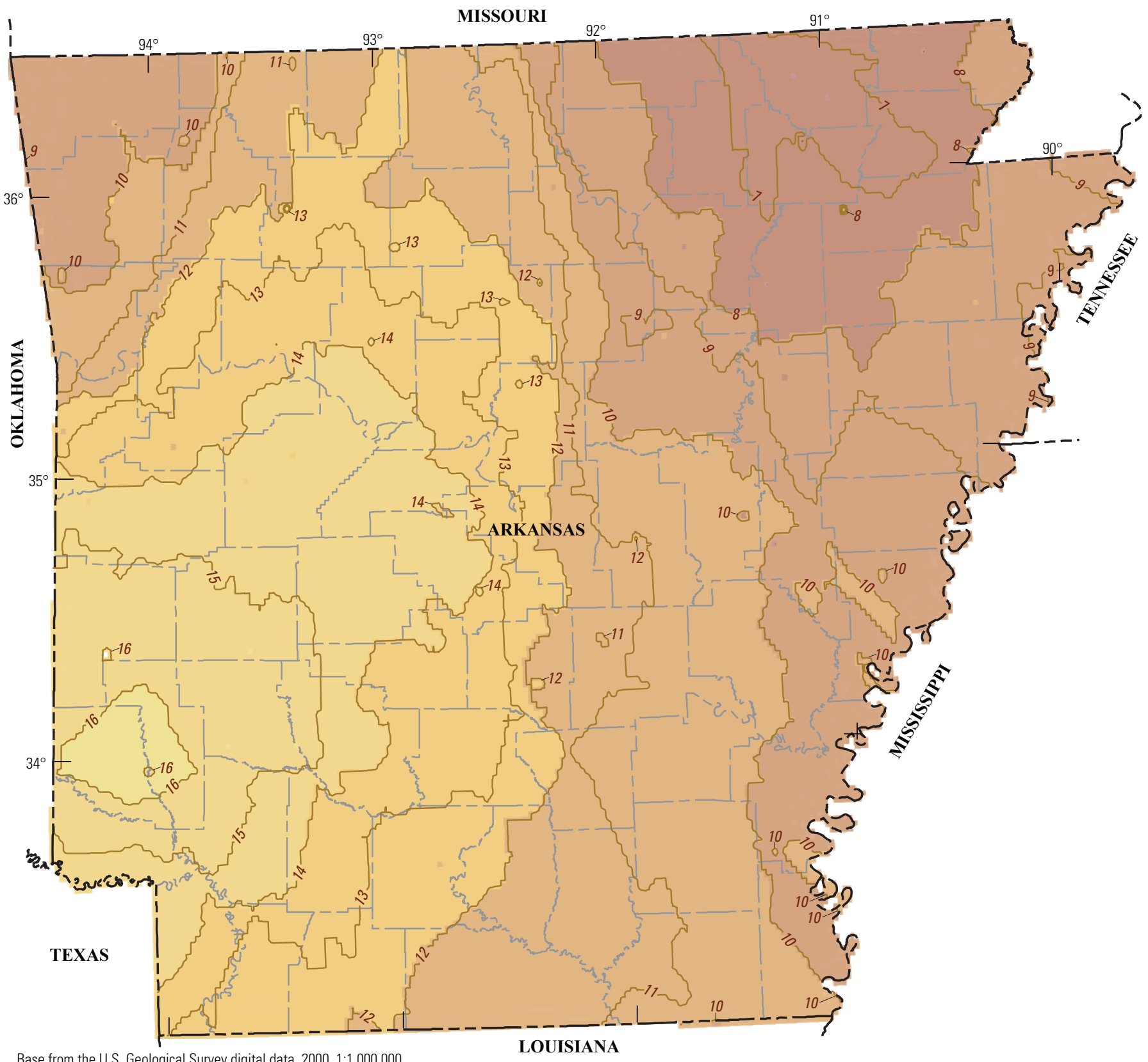

Base from the U.S. Geological Survey digital data, 2000, 1:1,000,000 USA Contiguous Albers Equal Area Conic USGS version North American Datum 1983

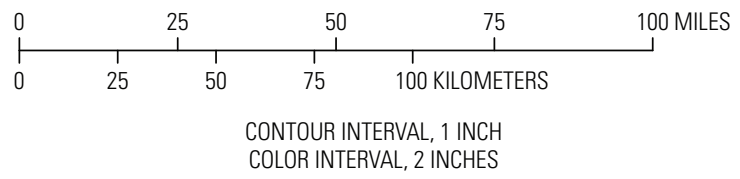

EXPLANATION

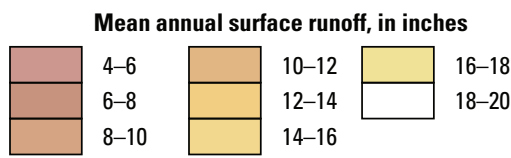

-10- Line of equal mean annual surface runoff, in

inches-Root mean squared error is 1.47 inches

Figure 11. Mean annual surface runoff in Arkansas, 1951-2011. 


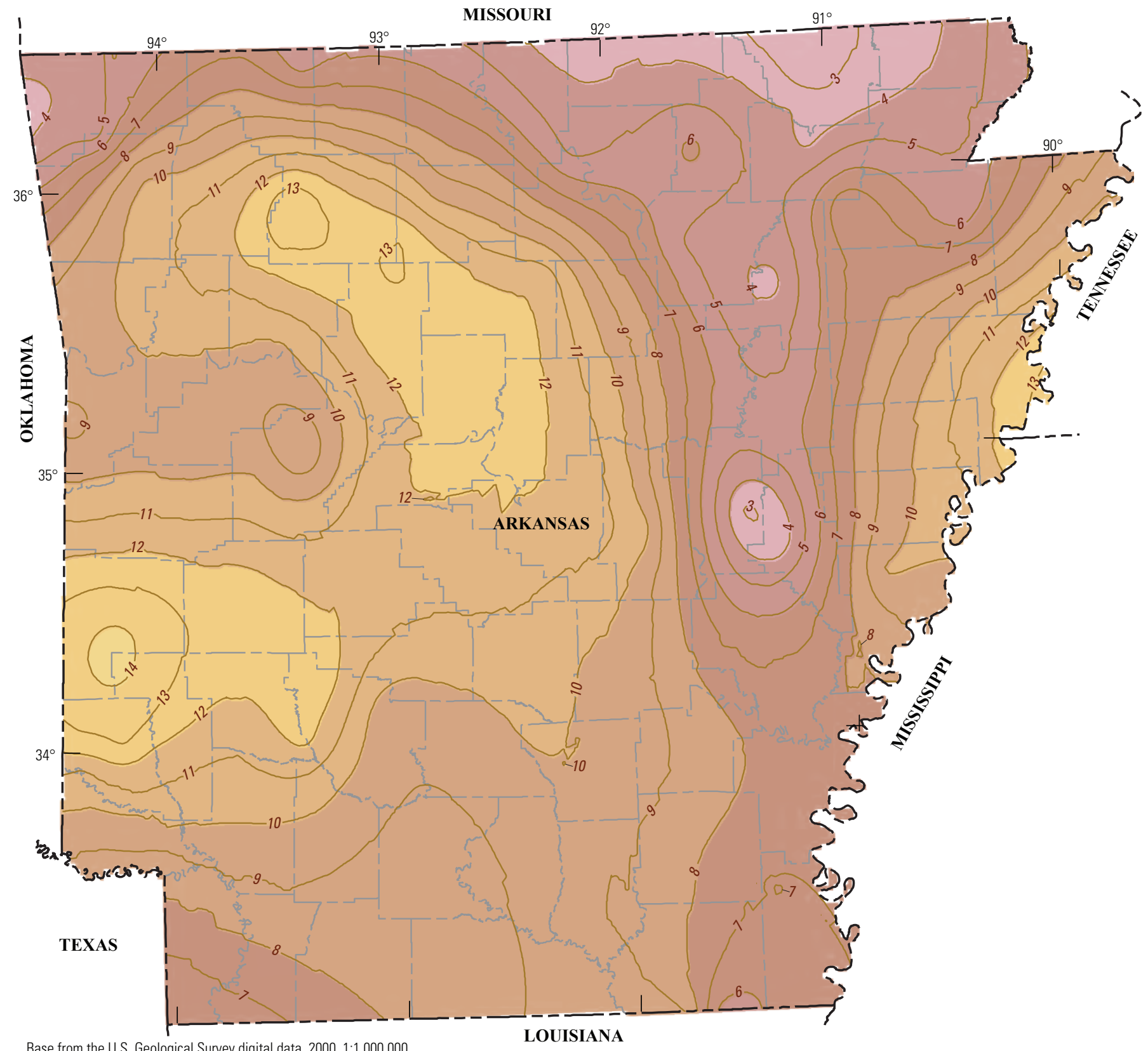

Base from the U.S. Geological Survey digital data, 2000, 1:1,000,000 USA Contiguous Albers Equal Area Conic USGS version North American Datum 1983

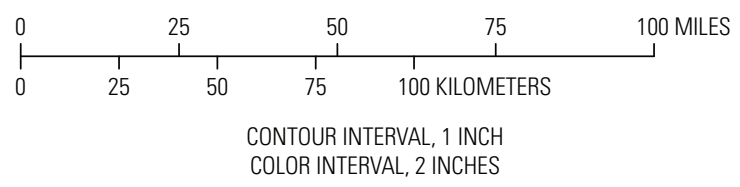

EXPLANATION

Mean wet season surface runoff, in inches

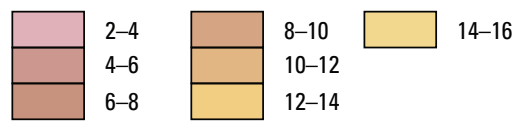

$-9-$ Line of equal mean wet season surface runoff, in inches-Root mean squared error is 0.49 inch

Figure 12. Map showing mean wet season surface runoff in Arkansas, 1951-2011. 


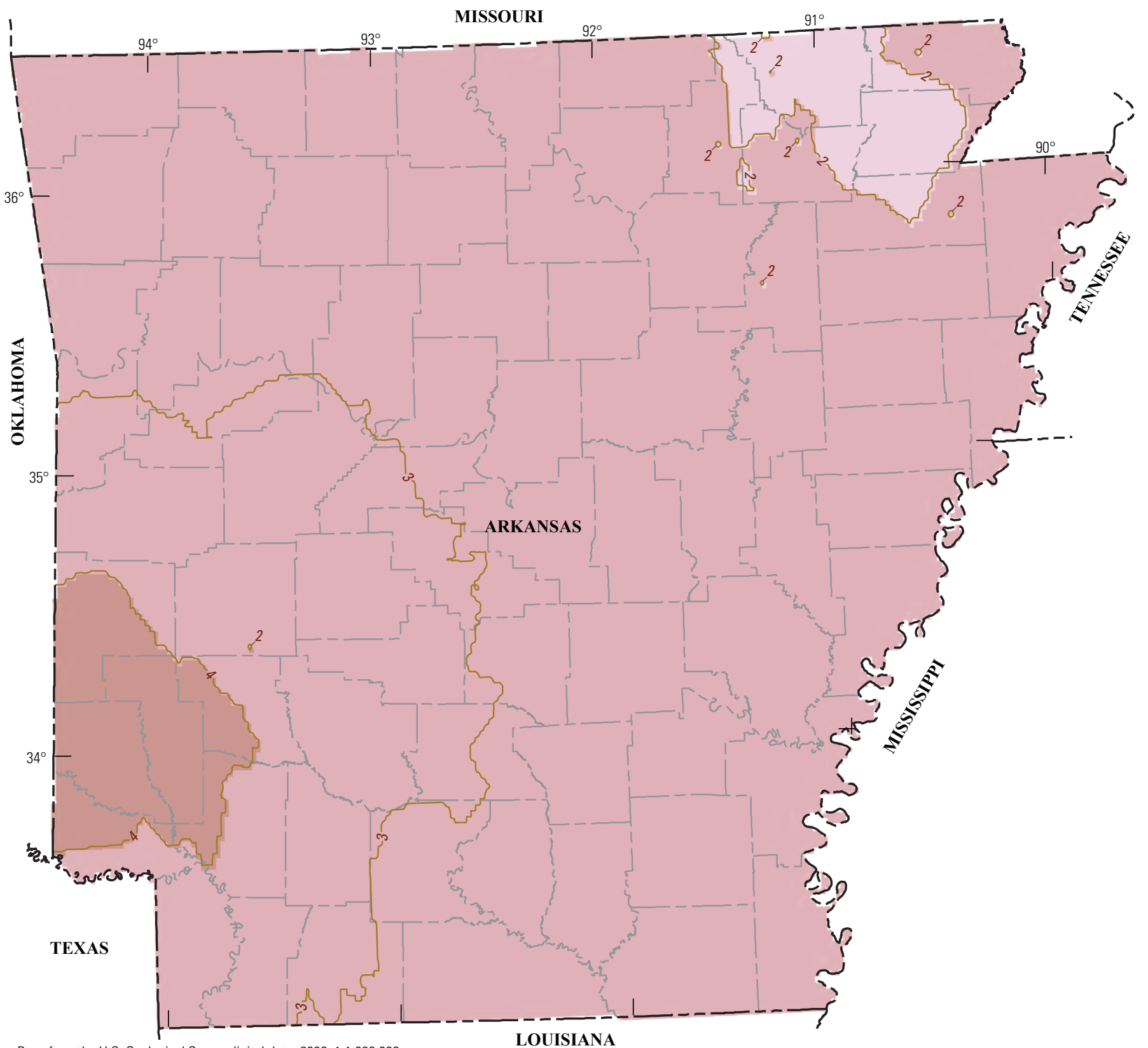

Base from the U.S. Geological Survey digital data, 2000, 1:1,000,000 USA Contiguous Albers Equal Area Conic USGS version

North American Datum 1983

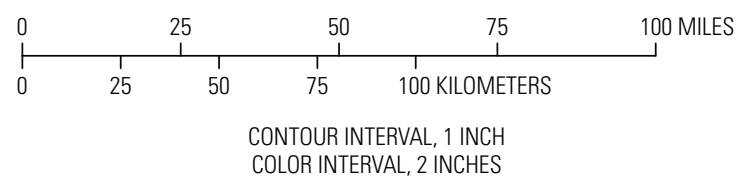

EXPLANATION

Mean dry season surface runoff, in inches

$0-2$

$4-6$

- 3- Line of equal mean dry season surface runoff, in inches-Root mean squared error is 0.59 inch

Figure 13. Map showing mean dry season surface runoff in Arkansas, 1951-2011. 

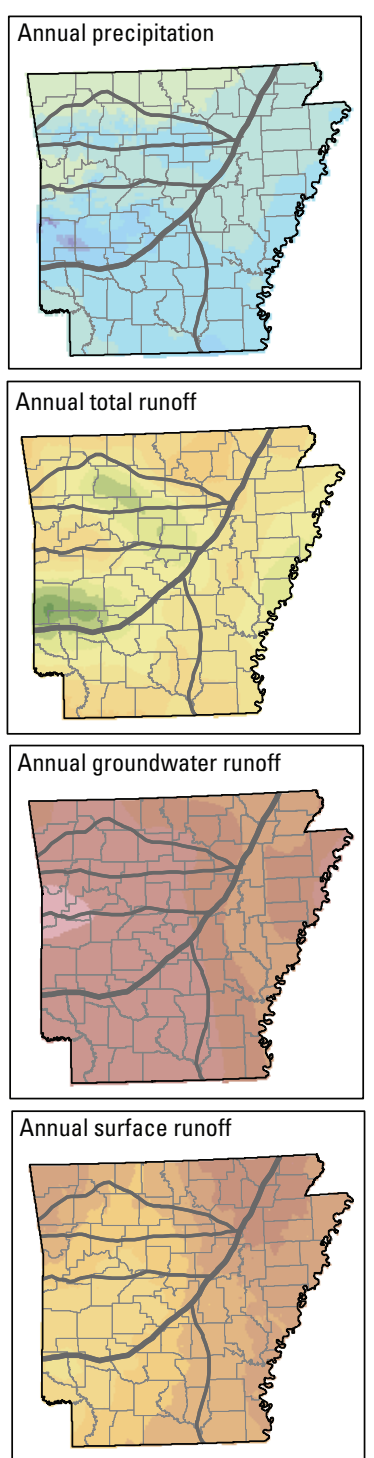

Base from the U.S. Geological Survey digital data, 2000, 1:1,000,000 USA Contiguous Albers Equal Area Conic USGS version North American Datum 1983

$2000,1 \cdot 1,000,000$

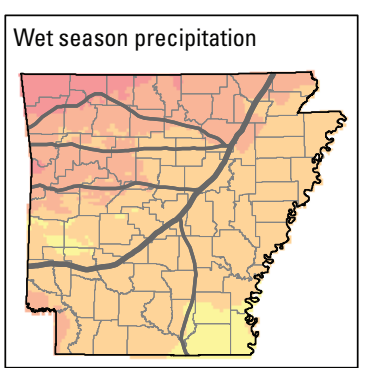

Wet season total runoff
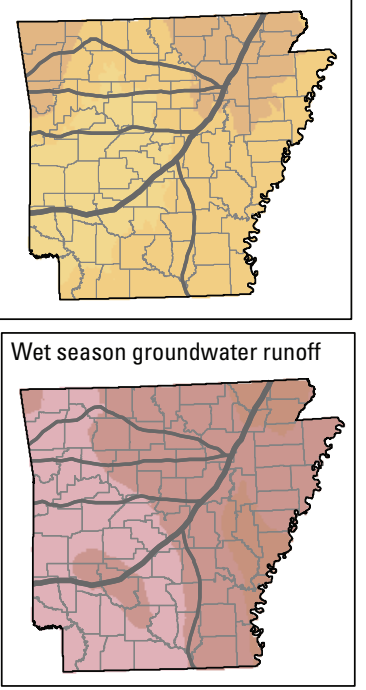

Wet season surface runoff

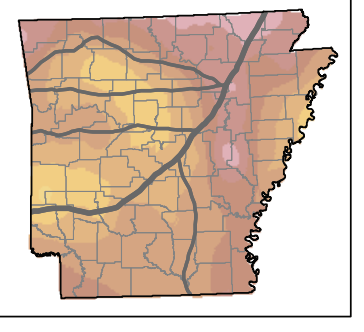
.

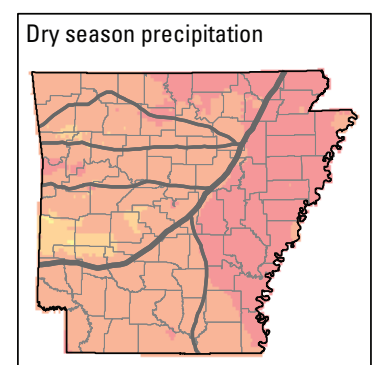

Dry season total runoff
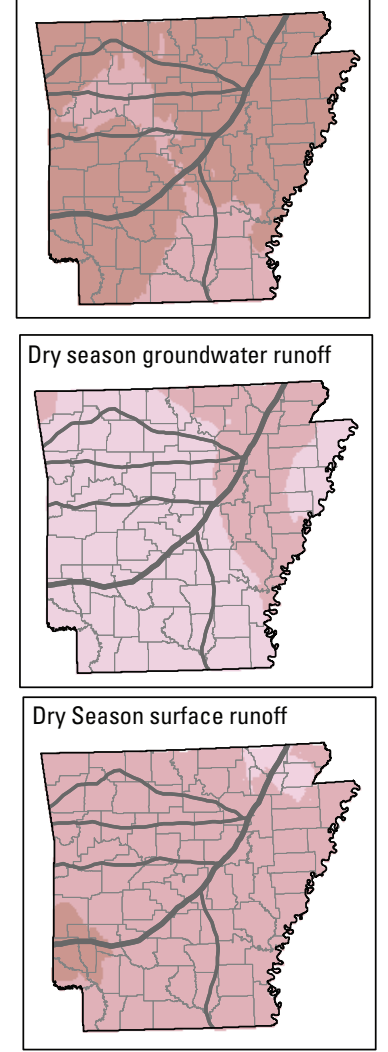
Modified from Fenneman, 1946

Figure 14. Maps showing mean annual and mean seasonal precipitation and runoff in Arkansas, 1951-2011.

\section{EXPLANATION}

\begin{tabular}{|c|c|}
\hline Precipitation, in inches & \multirow{2}{*}{$\begin{array}{l}\text { Runoff, in inches } \\
0-2\end{array}$} \\
\hline \multirow{2}{*}{$\begin{array}{l}18-22 \\
22-26\end{array}$} & \\
\hline & $2-4$ \\
\hline \multirow{3}{*}{$\begin{array}{l}26-30 \\
30-34 \\
34-38\end{array}$} & 4-6 \\
\hline & $6-8$ \\
\hline & $8-10$ \\
\hline \multirow{2}{*}{$42-46$} & $10-12$ \\
\hline & $12-14$ \\
\hline $\begin{array}{l}46-50 \\
50-54\end{array}$ & $14-16$ \\
\hline 54-58 & $16-18$ \\
\hline \multirow{5}{*}{$\begin{array}{l}58-62 \\
62-66\end{array}$} & $18-20$ \\
\hline & $20-22$ \\
\hline & $22-24$ \\
\hline & $24-26$ \\
\hline & $26-28$ \\
\hline
\end{tabular}

Boundary of phydiographic region Boundary of phydiographic section

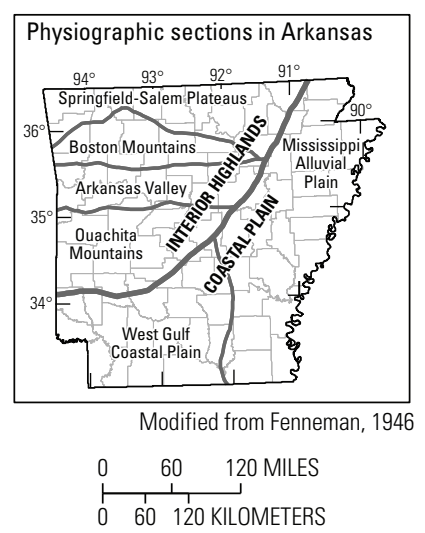

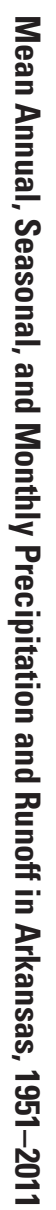




\section{Temporal Distribution of Precipitation and Runoff}

Precipitation for the period 1951-2011 in Arkansas was abundant and relatively evenly distributed through the year. The maximum mean monthly precipitation was in May (5.2 in., 10.6 percent of annual total), and the minimum was in August (3.0 in., 6.0 percent of annual total) (fig. 15, tables 4-5 at end of report). Similar distributions of precipitation were observed in each physiographic section, although maximum and minimum values varied and may have occurred in a preceding or succeeding month (fig. 16, tables 4-5).

Runoff for the period 1951-2011 in Arkansas had the same general pattern as precipitation. Arkansas' mean monthly total runoff was highest in March (2.6 in., 15.0 percent of annual total) and lowest in August ( 0.4 in., 2.3 percent of annual total) (fig. 15, tables 4-5). Similar distributions of runoff were observed in each physiographic section although maximum and minimum values varied and may have occurred in a preceding or succeeding month (fig. 16, tables 4-5).

During the dry season, the reduction in runoff results from decreased precipitation and increased losses from evapotranspiration and consumptive uses (increased irrigation, withdrawals for public and private water supplies). The reduction in runoff during the dry season is observed across the State in all physiographic sections (figs. 15-16, tables 3-5).

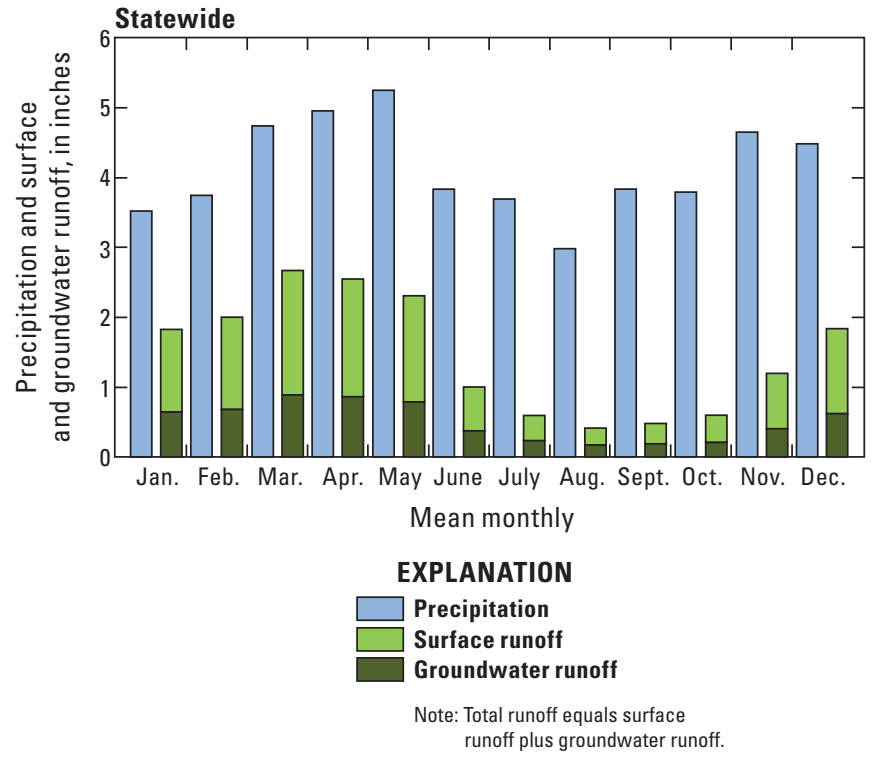

Figure 15. Mean monthly precipitation and runoff for Arkansas, 1951-2011. 


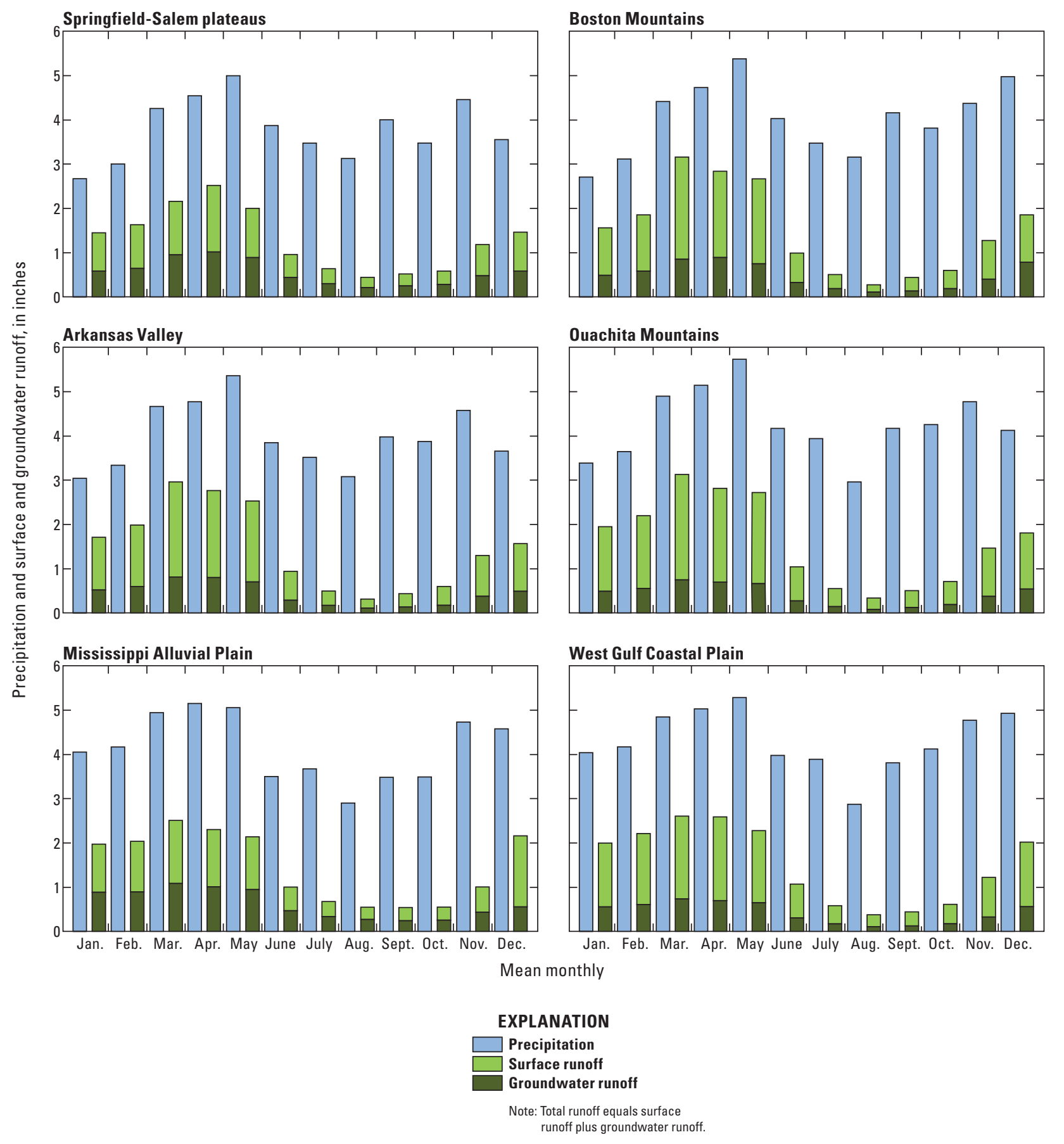

Figure 16. Mean monthly precipitation and runoff for physiographic sections in Arkansas, 1951-2011. 


\section{Summary}

This report describes long-term annual, seasonal, and monthly means for precipitation and runoff in Arkansas for the period from 1951 through 2011. Precipitation means were estimated using data from the Parameter-elevation Regressions on Independent Slopes Model database; while total runoff, groundwater runoff, and surface runoff means were estimated using data from 123 active and inactive U.S. Geological Survey continuous-record streamflow-gaging stations located in Arkansas and surrounding States. Precipitation in Arkansas is abundant and relatively well distributed throughout the year. Annual precipitation in Arkansas for the period from 1951 through 2011 had a mean of $49.8 \mathrm{in}$. Of the six physiographic sections in Arkansas, the Ouachita Mountains had the largest mean annual precipitation at 53.0 in., while the SpringfieldSalem plateaus had the smallest mean annual precipitation at 45.5 in. The mean wet season precipitation in Arkansas was 26.9 in. The Mississippi Alluvial Plain had the largest mean wet season precipitation at 28.3 in., and the Springfield-Salem plateaus had the smallest mean wet season precipitation at 23.2 in. The mean dry season precipitation in Arkansas was 22.9 in. The Ouachita Mountains had the largest mean dry season precipitation at 24.9 in., and the Mississippi Alluvial Plain had the smallest mean dry season precipitation at 21.6 in.

Arkansas exhibits a wide range of runoff values resulting from differences in climate, land use, vegetation, geology, soil type, elevation, slope, topography, drainage network patterns, lakes, and reservoirs. The mean annual total runoff for 1951-2011 in Arkansas was 17.8 in. The Ouachita Mountains had the largest mean annual total runoff at 20.4 in., while the Springfield-Salem plateaus had the smallest mean annual total runoff at 15.0 in. The mean annual groundwater runoff for Arkansas was 6.1 in. The Mississippi Alluvial Plain had the largest mean annual groundwater runoff at 7.5 in., while the Ouachita Mountains had the smallest mean annual groundwater runoff at $4.9 \mathrm{in}$. The mean annual surface runoff for Arkansas was 11.4 in. The Ouachita Mountains had the largest mean annual surface runoff at 14.5 in., while the Springfield-Salem plateaus had the smallest mean annual surface runoff at $9.3 \mathrm{in}$.

The mean wet season total runoff for 1951-2011 in Arkansas was 13.2 in. The Ouachita Mountains had the largest mean wet season total runoff at 14.8 in., and the SpringfieldSalem plateaus had the smallest mean wet season total runoff at $11.7 \mathrm{in}$. The mean wet season groundwater runoff for Arkansas was 4.5 in. The Mississippi Alluvial Plain had the largest mean wet season groundwater runoff at 5.6 in., while the Ouachita Mountains had the smallest mean wet season groundwater runoff at $3.7 \mathrm{in}$. The mean wet season surface runoff for Arkansas was 8.8 in. The Ouachita Mountains had the largest mean wet season surface runoff at 11.7 in., while the Springfield-Salem plateaus had the smallest mean wet season surface runoff at 5.7 in.
Runoff is diminished during the dry season, which is attributed to increased losses from evapotranspiration, consumptive uses including irrigation, and increased withdraws for public and private water supplies. The decline in runoff during the dry season is observed across the State in all physiographic sections. The mean dry season total runoff for Arkansas was 4.3 in. The Ouachita Mountains had the largest mean dry season total runoff at 4.6 in., while the Boston Mountains and Arkansas Valley had the smallest mean dry season total runoff at 4.1 in. The mean dry season groundwater runoff for Arkansas was 1.6 in. The SpringfieldSalem plateaus and the Mississippi Alluvial Plain had the largest mean dry season groundwater runoff at 2.0 in., while the Arkansas Valley, Ouachita Mountains, and West Gulf Coastal Plain had the smallest mean dry season groundwater runoff at $1.2 \mathrm{in}$. The mean dry season surface runoff for Arkansas was 2.7 in. The Ouachita Mountains had the largest mean dry season surface runoff at 3.4 in., while the Mississippi Alluvial Plain had the smallest mean dry season surface runoff at $2.3 \mathrm{in}$.

Precipitation and runoff for the period 1951 through 2011 in Arkansas was abundant and relatively evenly distributed through the year. Arkansas' mean monthly precipitation was largest in May at 5.2 in. (10.6 percent of annual total) and smallest in August at 3.0 in. (6.0 percent of annual total). Arkansas' mean monthly total runoff was largest in March at 2.6 in. (15.0 percent of annual total) and smallest in August with a value of 0.4 in. (2.3 percent of annual total). Similar distributions of precipitation and runoff were observed in each physiographic section, although maximum and minimum values varied and may have occurred in a preceding or succeeding month.

Estimates for precipitation and runoff are presented in a series of 12 single map figures and one multimap figure. The digital data used to create the 12 single map figures are available online in a GIS raster format and a KML compatible format (http://pubs.usgs.gov/sir/2014/5006/).

\section{References Cited}

Arkansas Geological Survey, 2013, Physiographic regions: Arkansas Geological Survey, accessed on September 13, 2013, at http://www.geology.ar.gov/education/physio_ regions.htm.

Busby, M.W., 1966, Annual runoff in the conterminous United States: U.S. Geological Survey Hydrologic Investigations Atlas 212, 1 sheet.

Clark, B.R., Hart, R.M., and Gurdak, J.J., 2011, Groundwater availability of the Mississippi embayment: U.S. Geological Survey Professional Paper 1785, 62 p. 
Daly, C., Halbleib, M., Smith, J.I., Gibson, W.P., Doggett, M.K., Taylor, G.H., Curtis, J., and Pasteris, P.A., 2008, Physiographically-sensitive mapping of temperature and precipitation across the conterminous United States: International Journal of Climatology, v. 28, no. 15, p. 2031-2064.

Dowdy, S.M., and Wearden, S., 1983, Statistics for research: New York, John Willey \& Sons, p. 173-196.

esri, 2010, ArcGIS 10 Help: ArcGIS Resources, Redlands, California, esri, accessed June 12, 2013, at http://resources. arcgis.com/en/help/.

Fenneman, N.M., 1946, Physical divisions of the United States: U.S. Geological Survey map, scale 1:7,000,000, 1 sheet.

Freiwald, D.A., 1984, Average annual precipitation and runoff for Arkansas, 1951-1980: U.S. Geological Survey WaterResources Investigations Report 84-4363, 4 maps on 1 sheet.

Foti, Thomas, 2011, Ouachita Mountains - Encyclopedia of Arkansas history and culture: Little Rock, Arkansas, Butler Center for Arkansas Studies, accessed on September 13, 2013, at http:/www.encyclopediaofarkansas.net/ encyclopedia/entry-detail.aspx?entryID=442.

Gebert, W.A., Graczyk, D.J, and Krug, W.R., 1987, Average annual runoff in the United States, 1951-1980: U.S. Geological Survey Hydrologic Atlas 710, 3 maps on 1 sheet.

Hedman, E.R., Skelton, John, and Freiwald, D.A., 1987. Flow characteristics for selected springs and streams in the Ozark subregion, Arkansas, Kansas, Missouri, and Oklahoma: U.S. Geological Survey Hydrologic Atlas 688, 4 maps.

Institute of Hydrology, 1980, Low flow studies: Wallingford, U.K., Institute of Hydrology Research Report 1, variously paged.

Justus, B.G., 2003, An index of ecological integrity for the Mississippi Alluvial Plain ecoregion-Index development and relations to selected landscape variables: U.S. Geological Survey Water-Resources Investigations Report 2003-4110, 32 p.

Langbein, W.B., 1949, Annual runoff in the United States: U.S. Geological Survey Circular 52, 14 p.

Langbein, W.B., and Iseri, Kathleen T., 1960, General introduction and hydrologic definitions: U.S. Geological Survey Water-Supply Paper 1541-A, 29 p.

Moix, M.W., and Galloway, J.M., 2004, Base flow, water quality, and streamflow gain and loss of the Buffalo River, Arkansas, and selected tributaries, July and August 2003: U.S. Geological Survey Scientific Investigations Report 2004-5274, 36 p.
Patterson, J.L., 1971, Floods in Arkansas, magnitude and frequency characteristics through 1968: Arkansas Geological Commission Water Resources Circular No. 11, $21 \mathrm{p}$.

PRISM Climate Group, 2013, PRISM Climate Data: Corvallis, Oregon, Oregon State University, accessed January 26, 2013, at http://prism.oregonstate.edu.

Schrader, T.P., 2008, Water levels and selected water-quality conditions in the Mississippi River Valley alluvial aquifer in eastern Arkansas, 2006: U.S. Geological Survey Scientific Investigations Report 2008-5092, 73 p.

Schrader, T.P., 2010, Water levels and selected water-quality conditions in the Mississippi River Valley alluvial aquifer in eastern Arkansas, 2008: U.S. Geological Survey Scientific Investigations Report 2010-5140, 71 p.

U.S. Department of Agriculture, 1971, Soil survey Franklin County, Arkansas: Soil Conservation Service, 94 p.

U.S. Department of Agriculture, 1975a, Soil survey Howard County, Arkansas: Soil Conservation Service, 75 p.

U.S. Department of Agriculture, 1975b, Soil survey of Sebastian County, Arkansas: Soil Conservation Service, 66 p.

U.S. Department of Agriculture, 1978, Soil survey of Monroe County, Arkansas: Soil Conservation Service, 83 p.

U.S. Geological Survey, 2013, USGS water data for the Nation: National Water Information System, accessed May 10, 2013, at http://waterdata.usgs.gov/nwis.

Wahl, K.L., and Wahl, T.L., 1988, Effects of regional groundwater declines on streamflows in the Oklahoma Panhandle, in Proceedings of Symposium on Water-Use-Data for Water Resources Management: Tucson, Arizona, American Water Resources Association, p. 239-294. (Also available at http:// www.usbr.gov/pmts/hydraulics_lab/twahl/bfi/bfi_beaver_ river.pdf.)

Wahl, K.L., and Wahl, T.L., 1995, Determining the flow of Comal Springs at New Braunfels, Texas, in Proceedings of Texas Water '95, August 16-17, 1995, San Antonio, Texas: American Society of Civil Engineers, p. 77-86. (Also available at http://www.usbr.gov/pmts/hydraulics_lab/twahl/ bfi/texaswater95/comalsprings.html.)

Wolock, D.M., 2003a, Base-flow index grid for the conterminous United States: U.S. Geological Survey OpenFile Report 03-263, digital data set, accessed May 6, 2013, at http://water.usgs.gov/lookup/getspatial?bfi48grd.

Wolock, D.M. 2003b, Estimated mean annual natural groundwater recharge in the conterminous United States: U.S. Geological Survey Open-File Report 03-311, digital data set, accessed May 6, 2013, at http:/water.usgs.gov/lookup/ getspatial?rech48grd 
Table 1. Selected continuous-streamflow gaging stations analyzed for runoff within Arkansas and surrounding States.

[dd, degrees and decimal degrees; $\mathrm{mi}^{2}$, square miles]

\begin{tabular}{|c|c|c|c|c|c|c|c|}
\hline \multirow{2}{*}{$\begin{array}{l}\text { Map } \\
\text { num- } \\
\text { ber }\end{array}$} & \multirow{2}{*}{$\begin{array}{l}\text { Station } \\
\text { number }\end{array}$} & \multirow{2}{*}{ Station name } & \multirow{2}{*}{$\begin{array}{l}\text { Latitude } \\
\text { (dd) }\end{array}$} & \multirow{2}{*}{$\begin{array}{l}\text { Longitude } \\
\text { (dd) }\end{array}$} & \multirow{2}{*}{$\begin{array}{c}\text { Contributing } \\
\text { drainage area } \\
\qquad\left(\mathrm{mi}^{2}\right)\end{array}$} & \multicolumn{2}{|c|}{$\begin{array}{c}\text { Period of } \\
\text { measurements }\end{array}$} \\
\hline & & & & & & $\begin{array}{l}\text { Start } \\
\text { year }\end{array}$ & $\begin{array}{l}\text { End } \\
\text { year }\end{array}$ \\
\hline 1 & 07026040 & Obion River at Highway 51 near Obion, Tenn. & 36.2408 & -89.2176 & 1,875 & 1930 & 2010 \\
\hline 2 & 07026500 & Reelfoot Creek near Samburg, Tenn. & 36.4423 & -89.2965 & 110 & 1951 & 1972 \\
\hline 3 & 07032200 & Nonconnah Creek near Germantown, Tenn. & 35.0498 & -89.8190 & 68.2 & 1970 & 2010 \\
\hline 5 & 07035500 & Barnes Creek near Fredericktown, Mo. & 37.5724 & -90.3837 & 4.03 & 1956 & 1974 \\
\hline 6 & 07035800 & St. Francis River near Mill Creek, Mo. & 37.5024 & -90.4579 & 505 & 1988 & 2011 \\
\hline 7 & 07036100 & St. Francis River near Saco, Mo. & 37.3845 & -90.4739 & 664 & 1984 & 2011 \\
\hline 8 & 07037000 & Big Creek at Des Arc, Mo. & 37.2925 & -90.6290 & 99.6 & 1984 & 2003 \\
\hline 12 & 07040100 & St. Francis River at St. Francis, Ark. & 36.4556 & -90.1378 & 1,770 & 1931 & 2009 \\
\hline 13 & 07040450 & St. Francis River at Lake City, Ark. & 35.8208 & -90.4325 & 2,370 & 1931 & 2009 \\
\hline 14 & 07043500 & Little River Ditch No. 1 near Morehouse, Mo. & 36.8345 & -89.7301 & 450 & 1946 & 2011 \\
\hline 15 & 07047600 & Tyronza River near Tyronza, Ark. & 35.5051 & -90.3801 & 290 & 1950 & 1973 \\
\hline 16 & 07047942 & LAnguille River near Colt, Ark. & 35.1447 & -90.8781 & 535 & 1971 & 2011 \\
\hline 17 & 07047950 & LAnguille River at Palestine, Ark. & 34.9728 & -90.8856 & 786 & 1950 & 2010 \\
\hline 18 & 07048000 & West Fork White River at Greenland, Ark. & 35.9829 & -94.1726 & 83.1 & 1946 & 1982 \\
\hline 19 & 07048600 & White River near Fayetteville, Ark. & 36.0731 & -94.0811 & 400 & 1964 & 2011 \\
\hline 20 & 07049000 & War Eagle Creek near Hindsville, Ark. & 36.2000 & -93.8550 & 263 & 1953 & 2011 \\
\hline 27 & 07057000 & Buffalo River near Rush, Ark. & 36.1173 & -92.5546 & 1,096 & 1929 & 1969 \\
\hline 28 & 07057500 & North Fork River near Tecumseh, Mo. & 36.6230 & -92.2481 & 561 & 1945 & 2011 \\
\hline 29 & 07060500 & White River at Calico Rock, Ark. & 36.1167 & -92.1431 & 9,980 & 1943 & 2011 \\
\hline 30 & 07060710 & North Sylamore Creek near Fifty Six, Ark. & 35.9917 & -92.2139 & 58.1 & 1966 & 2011 \\
\hline 31 & 07061000 & White River at Batesville, Ark. & 35.7603 & -91.6411 & 11,070 & 1951 & 2011 \\
\hline 32 & 07061500 & Black River near Annapolis, Mo. & 37.3381 & -90.7888 & 484 & 1940 & 2011 \\
\hline 33 & 07063000 & Black River at Poplar Bluff, Mo. & 36.7596 & -90.3881 & 1,245 & 1951 & 2011 \\
\hline 34 & 07064000 & Black River near Corning, Ark. & 36.4019 & -90.5414 & 1,750 & 1948 & 2011 \\
\hline 35 & 07068000 & Current River at Doniphan, Mo. & 36.6220 & -90.8476 & 2,038 & 1922 & 2011 \\
\hline 36 & 07069000 & Black River at Pocahontas, Ark. & 36.2542 & -90.9703 & 4,840 & 1951 & 2011 \\
\hline 37 & 07069500 & Spring River at Imboden, Ark. & 36.2056 & -91.1717 & 1,180 & 1937 & 2011 \\
\hline 38 & 07071500 & Eleven Point River near Bardley, Mo. & 36.6487 & -91.2008 & 793 & 1951 & 2011 \\
\hline 39 & 07072000 & Eleven Point River near Ravenden Springs, Ark. & 36.3464 & -91.1142 & 1,130 & 1930 & 2011 \\
\hline 40 & 07072500 & Black River at Black Rock, Ark. & 36.1025 & -91.0978 & 7,370 & 1948 & 2011 \\
\hline 41 & 07073000 & Strawberry River near Evening Shade, Ark. & 36.0990 & -91.6085 & 217 & 1940 & 1978 \\
\hline
\end{tabular}


Table 1. Selected continuous-streamflow gaging stations analyzed for runoff within Arkansas and surrounding States. - Continued [dd, degrees and decimal degrees; $\mathrm{mi}^{2}$, square miles]

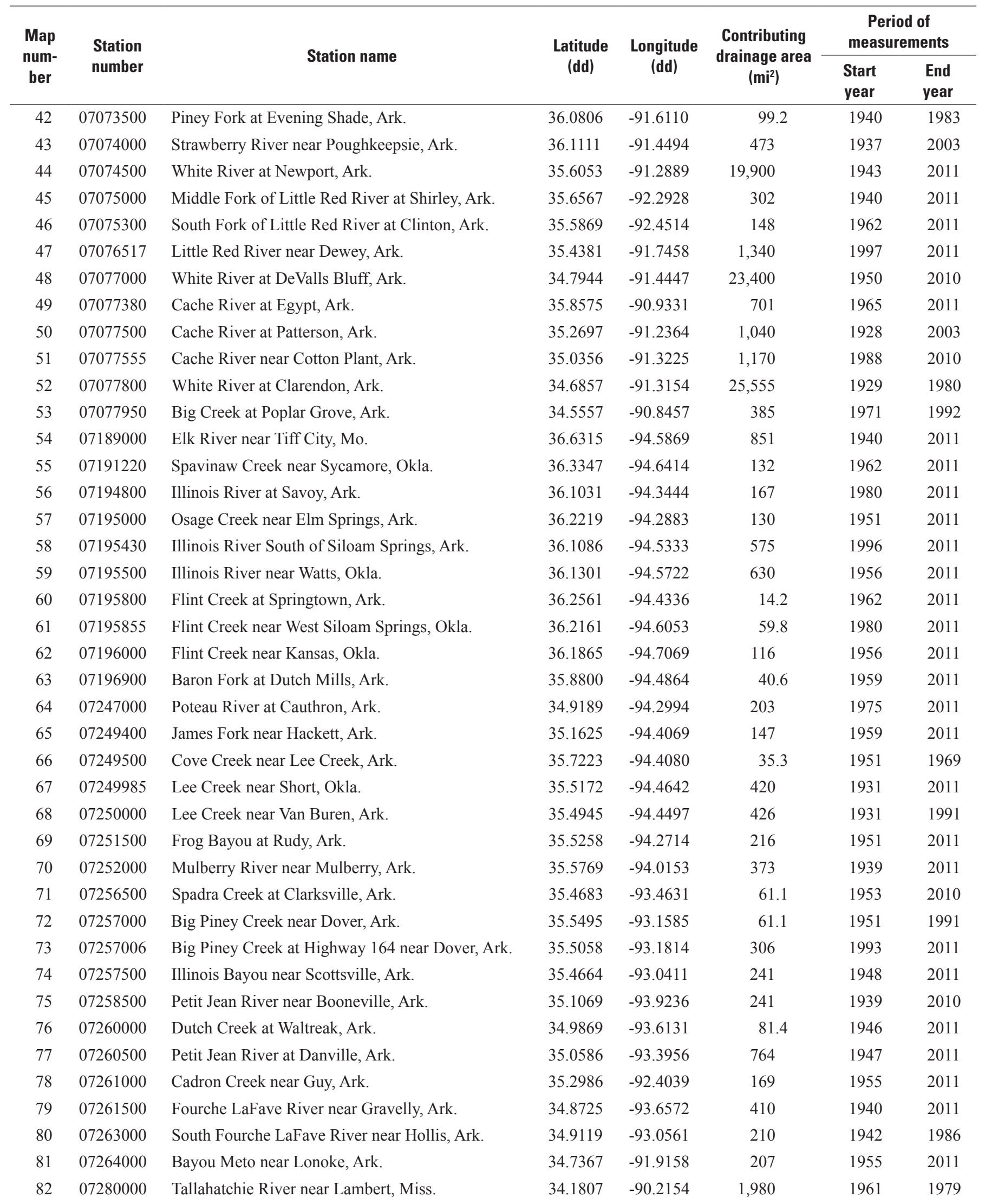


Table 1. Selected continuous-streamflow gaging stations analyzed for runoff within Arkansas and surrounding States.-Continued [dd, degrees and decimal degrees; $\mathrm{mi}^{2}$, square miles]

\begin{tabular}{|c|c|c|c|c|c|c|c|}
\hline \multirow{2}{*}{$\begin{array}{c}\text { Map } \\
\text { num- } \\
\text { ber }\end{array}$} & \multirow{2}{*}{$\begin{array}{l}\text { Station } \\
\text { number }\end{array}$} & \multirow{2}{*}{ Station name } & \multirow{2}{*}{$\begin{array}{l}\text { Latitude } \\
\text { (dd) }\end{array}$} & \multirow{2}{*}{$\begin{array}{l}\text { Longitude } \\
\text { (dd) }\end{array}$} & \multirow{2}{*}{$\begin{array}{c}\text { Contributing } \\
\text { drainage area } \\
\left(\mathrm{mi}^{2}\right)\end{array}$} & \multicolumn{2}{|c|}{$\begin{array}{c}\text { Period of } \\
\text { measurements }\end{array}$} \\
\hline & & & & & & $\begin{array}{l}\text { Start } \\
\text { year }\end{array}$ & $\begin{array}{l}\text { End } \\
\text { year }\end{array}$ \\
\hline 83 & 07287000 & Yazoo River at Greenwood, Miss. & 33.5244 & -90.1817 & 7,450 & 1908 & 1979 \\
\hline 84 & 07288500 & Big Sunflower River at Sunflower, Miss. & 33.5473 & -90.5431 & 767 & 1936 & 2010 \\
\hline 85 & 07290000 & Big Black River near Bovina, Miss. & 32.3478 & -90.6969 & 2,812 & 1937 & 2010 \\
\hline 87 & 07338500 & Little River below Lukfata Creek, near Idabel, Okla. & 33.9412 & -94.7585 & 1,228 & 1971 & 2011 \\
\hline 88 & 07339000 & Mountain Fork near Eagletown, Okla. & 34.0418 & -94.6199 & 800 & 1970 & 2011 \\
\hline 89 & 07339500 & Rolling Fork near DeQueen, Ark. & 34.0475 & -94.4128 & 182 & 1949 & 1979 \\
\hline 90 & 07340000 & Little River near Horatio, Ark. & 33.9194 & -94.3867 & 2,660 & 1969 & 2011 \\
\hline 94 & 07341200 & Saline River near Lockesburg, Ark. & 33.9622 & -94.0617 & 256 & 1975 & 2011 \\
\hline 95 & 07342500 & South Sulphur River near Cooper, Tex. & 33.3565 & -95.5950 & 527 & 1992 & 2011 \\
\hline 96 & 07343500 & White Oak Creek near Talco, Tex. & 33.3223 & -95.0927 & 494 & 1973 & 2011 \\
\hline 97 & 07346000 & Big Cypress Bayou near Jefferson, Tex. & 32.7496 & -94.4988 & 850 & 1958 & 2011 \\
\hline 98 & 07346070 & Little Cypress Bayou near Jefferson, Tex. & 32.7129 & -94.3460 & 675 & 1947 & 2011 \\
\hline 99 & 07348700 & Bayou Dorcheat near Springhill, La. & 32.9946 & -93.3966 & 605 & 1958 & 2011 \\
\hline 100 & 07349500 & Bodcau Bayou near Sarepta, La. & 32.9051 & -93.4830 & 546 & 1951 & 1991 \\
\hline 101 & 07356000 & Ouachita River near Mount Ida, Ark. & 34.6100 & -93.6975 & 414 & 1942 & 2011 \\
\hline 102 & 07356500 & South Fork Ouachita River at Mount Ida, Ark. & 34.5604 & -93.6360 & 61 & 1950 & 1969 \\
\hline 109 & 07362000 & Ouachita River at Camden, Ark. & 33.5964 & -92.8181 & 5,360 & 1929 & 2011 \\
\hline 110 & 07362100 & Smackover Creek near Smackover, Ark. & 33.3753 & -92.7767 & 385 & 1962 & 2011 \\
\hline 111 & 07362500 & Moro Creek near Fordyce, Ark. & 33.7922 & -92.3333 & 240 & 1952 & 2012 \\
\hline 112 & 07363000 & Saline River at Benton, Ark. & 34.5678 & -92.6103 & 550 & 1951 & 2011 \\
\hline 113 & 07363200 & Saline River near Sheridan, Ark. & 34.1161 & -92.4056 & 1,120 & 1971 & 2011 \\
\hline 114 & 07363300 & Hurricane Creek near Sheridan, Ark. & 34.3195 & -92.3446 & 204 & 1962 & 1994 \\
\hline 115 & 07363400 & Hurricane Creek below Sheridan, Ark. & 34.2286 & -92.3725 & 261 & 1996 & 2011 \\
\hline 116 & 07363500 & Saline River near Rye, Ark. & 33.7008 & -92.0258 & 2,100 & 1938 & 2011 \\
\hline 117 & 07364133 & Bayou Bartholomew at Garrett Bridge, Ark. & 33.8664 & -91.6561 & 380 & 1988 & 2011 \\
\hline 118 & 07364150 & Bayou Bartholomew near McGehee, Ark. & 33.6278 & -91.4458 & 576 & 1939 & 2011 \\
\hline 119 & 07364200 & Bayou Bartholomew near Jones, La. & 32.9904 & -91.6557 & 1,187 & 1983 & 2011 \\
\hline 120 & 07364300 & Chemin-A-Haut Bayou near Beekman, La. & 32.9821 & -91.8057 & 271 & 1956 & 1978 \\
\hline 121 & 07364700 & Bayou De Loutre near Laran, La. & 32.9554 & -92.4999 & 141 & 1956 & 1976 \\
\hline 122 & 07365800 & Cornie Bayou near Three Creeks, La. & 33.0381 & -92.9406 & 180 & 1957 & 1986 \\
\hline 123 & 07366200 & Little Corney Bayou near Lillie, La. & 32.9293 & -92.6329 & 208 & 1956 & 2011 \\
\hline
\end{tabular}


[mi² , square miles; in., inches; GW, groundwater; note: precipitation values derived from PRISM data]

\begin{tabular}{|c|c|c|c|c|c|c|c|c|c|c|c|}
\hline \multirow[b]{2}{*}{$\begin{array}{c}\text { Map } \\
\text { number }\end{array}$} & \multirow[b]{2}{*}{$\begin{array}{l}\text { Station } \\
\text { number }\end{array}$} & \multirow[b]{2}{*}{ Station name } & \multirow{2}{*}{$\begin{array}{l}\text { Contributing } \\
\text { drainage } \\
\text { area } \\
\left(\mathrm{mi}^{2}\right)\end{array}$} & \multicolumn{3}{|c|}{ Period of measurements } & \multirow[b]{2}{*}{$\begin{array}{l}\text { Base- } \\
\text { flow } \\
\text { index }\end{array}$} & \multicolumn{4}{|c|}{ Mean annual } \\
\hline & & & & $\begin{array}{l}\text { Start } \\
\text { year }\end{array}$ & $\begin{array}{l}\text { End } \\
\text { year }\end{array}$ & $\begin{array}{l}\text { Number } \\
\text { of years } \\
\text { analyzed }\end{array}$ & & $\begin{array}{l}\text { Precip- } \\
\text { itation } \\
\text { (in.) }\end{array}$ & $\begin{array}{c}\text { Total } \\
\text { runoff } \\
\text { (in.) } \\
\end{array}$ & $\begin{array}{c}\text { GW } \\
\text { runoff } \\
\text { (in.) }\end{array}$ & $\begin{array}{c}\text { Surface } \\
\text { runoff } \\
\text { (in.) }\end{array}$ \\
\hline 1 & 07026040 & Obion River at Highway 51 near Obion, Tenn. & 1,875 & 1930 & 2010 & 44 & 0.38 & 50.76 & 20.95 & 7.95 & 12.98 \\
\hline 2 & 07026500 & Reelfoot Creek near Samburg, Tenn. & 110 & 1951 & 1972 & 22 & 0.078 & 50.61 & 14.58 & 1.16 & 13.70 \\
\hline 3 & 07032200 & Nonconnah Creek near Germantown, Tenn. & 68.2 & 1970 & 2010 & 37 & 0.029 & 52.89 & 20.00 & 0.63 & 20.99 \\
\hline 4 & 07035000 & Little St. Francis River at Fredericktown, Mo. & 90.5 & 1984 & 2011 & 19 & 0.255 & 43.78 & 18.45 & 4.68 & 13.66 \\
\hline 5 & 07035500 & Barnes Creek near Fredericktown, Mo. & 4.03 & 1956 & 1974 & 19 & 0.157 & 43.59 & 16.34 & 2.57 & 13.81 \\
\hline 6 & 07035800 & St. Francis River near Mill Creek, Mo. & 505 & 1988 & 2011 & 21 & 0.263 & 44.24 & 15.95 & 4.11 & 11.51 \\
\hline 7 & 07036100 & St. Francis River near Saco, Mo. & 664 & 1984 & 2011 & 19 & 0.258 & 44.74 & 19.13 & 4.93 & 14.18 \\
\hline 8 & 07037000 & Big Creek at Des Arc, Mo. & 99.6 & 1984 & 2003 & 18 & 0.358 & 45.18 & 19.87 & 7.09 & 12.72 \\
\hline 9 & 07037500 & St. Francis River near Patterson, Mo. & 956 & 1922 & 2011 & 59 & 0.304 & 45.81 & 16.41 & 4.97 & 11.39 \\
\hline 10 & 07037700 & Clark Creek near Piedmont, Mo. & 4.39 & 1957 & 1975 & 19 & 0.32 & 45.74 & 14.23 & 4.25 & 9.02 \\
\hline 11 & 07039500 & St. Francis River at Wappapello, Mo. & 1,311 & 1942 & 2011 & 59 & 0.489 & 47.33 & 16.19 & 7.90 & 8.25 \\
\hline 12 & 07040100 & St. Francis River at St. Francis, Ark. & 1,770 & 1931 & 2009 & 47 & 0.532 & 46.62 & 16.24 & 8.62 & 7.58 \\
\hline 13 & 07040450 & St. Francis River at Lake City, Ark. & 2,370 & 1931 & 2009 & 36 & 0.647 & 48.33 & 16.55 & 10.51 & 5.73 \\
\hline 14 & 07043500 & Little River Ditch No. 1 near Morehouse, Mo. & 450 & 1946 & 2011 & 55 & 0.371 & 46.56 & 16.46 & 6.07 & 10.29 \\
\hline 15 & 07047600 & Tyronza River near Tyronza, Ark. & 290 & 1950 & 1973 & 23 & 0.259 & 49.28 & 18.70 & 4.91 & 14.05 \\
\hline 16 & 07047942 & LAnguille River near Colt, Ark. & 535 & 1971 & 2011 & 41 & 0.339 & 49.69 & 18.31 & 6.17 & 12.04 \\
\hline 17 & 07047950 & LAnguille River at Palestine, Ark. & 786 & 1950 & 2010 & 39 & 0.363 & 50.17 & 18.53 & 6.63 & 11.63 \\
\hline 18 & 07048000 & West Fork White River at Greenland, Ark. & 83.1 & 1946 & 1982 & 32 & 0.235 & 45.72 & 16.69 & 3.90 & 12.69 \\
\hline 19 & 07048600 & White River near Fayetteville, Ark. & 400 & 1964 & 2011 & 44 & 0.271 & 44.88 & 19.04 & 5.10 & 13.73 \\
\hline 20 & 07049000 & War Eagle Creek near Hindsville, Ark. & 263 & 1953 & 2011 & 30 & 0.277 & 44.71 & 16.71 & 4.24 & 11.07 \\
\hline 21 & 07050500 & Kings River near Berryville, Ark. & 527 & 1940 & 2011 & 40 & 0.309 & 44.06 & 14.75 & 4.61 & 10.32 \\
\hline 22 & 07052500 & James River at Galena, Mo. & 987 & 1922 & 2011 & 61 & 0.444 & 43.53 & 13.68 & 6.06 & 7.59 \\
\hline 23 & 07053250 & Yocum Creek near Oak Grove, Ark. & 52.8 & 1994 & 2011 & 18 & 0.428 & 43.54 & 12.91 & 5.22 & 6.97 \\
\hline 24 & 07055646 & Buffalo River near Boxley, Ark. & 57.4 & 1994 & 2011 & 15 & 0.236 & 46.42 & 24.64 & 5.75 & 18.61 \\
\hline 25 & 07055875 & Richland Creek near Witts Spring, Ark. & 67.4 & 1996 & 2011 & 16 & 0.264 & 48.94 & 23.87 & 6.22 & 17.33 \\
\hline 26 & 07056000 & Buffalo River near St. Joe, Ark. & 829 & 1940 & 2011 & 61 & 0.331 & 44.05 & 17.12 & 5.65 & 11.42 \\
\hline 27 & 07057000 & Buffalo River near Rush, Ark. & 1,096 & 1929 & 1969 & 19 & 0.332 & 44.54 & 14.67 & 4.86 & 9.77 \\
\hline 28 & 07057500 & North Fork River near Tecumseh, Mo. & 561 & 1945 & 2011 & 61 & 0.722 & 43.37 & 17.60 & 12.67 & 4.88 \\
\hline 29 & 07060500 & White River at Calico Rock, Ark. & 9,980 & 1943 & 2011 & 61 & 0.497 & 45.42 & 13.61 & 6.75 & 6.83 \\
\hline 30 & 07060710 & North Sylamore Creek near Fifty Six, Ark. & 58.1 & 1966 & 2011 & 46 & 0.276 & 45.82 & 11.29 & 3.10 & 8.12 \\
\hline 31 & 07061000 & White River at Batesville, Ark. & 11,070 & 1951 & 2011 & 25 & 0.548 & 47.72 & 14.99 & 8.69 & 7.17 \\
\hline
\end{tabular}


Table 2. Estimated precipitation and runoff values for selected continuous-record streamflow-gaging stations within Arkansas and surrounding States. - Continued

[mi², square miles; in., inches; GW, groundwater; note: precipitation values derived from PRISM data]

\begin{tabular}{|c|c|c|c|c|c|c|c|c|c|c|c|}
\hline \multirow[b]{2}{*}{$\begin{array}{c}\text { Map } \\
\text { number }\end{array}$} & \multirow[b]{2}{*}{$\begin{array}{l}\text { Station } \\
\text { number }\end{array}$} & \multirow[b]{2}{*}{ Station name } & \multirow{2}{*}{$\begin{array}{c}\text { Contributing } \\
\text { drainage } \\
\text { area } \\
\left(\mathrm{mi}^{2}\right)\end{array}$} & \multicolumn{3}{|c|}{ Period of measurements } & \multirow[b]{2}{*}{$\begin{array}{l}\text { Base- } \\
\text { flow } \\
\text { index }\end{array}$} & \multicolumn{4}{|c|}{ Mean annual } \\
\hline & & & & $\begin{array}{l}\text { Start } \\
\text { year }\end{array}$ & $\begin{array}{l}\text { End } \\
\text { year }\end{array}$ & $\begin{array}{l}\text { Number } \\
\text { of years } \\
\text { analyzed }\end{array}$ & & $\begin{array}{l}\text { Precip- } \\
\text { itation } \\
\text { (in.) }\end{array}$ & $\begin{array}{c}\text { Total } \\
\text { runoff } \\
\text { (in.) }\end{array}$ & $\begin{array}{l}\text { GW } \\
\text { runoff } \\
\text { (in.) }\end{array}$ & $\begin{array}{c}\text { Surface } \\
\text { runoff } \\
\text { (in.) }\end{array}$ \\
\hline 32 & 07061500 & Black River near Annapolis, Mo. & 484 & 1940 & 2011 & 61 & 0.469 & 45.10 & 16.88 & 7.89 & 8.93 \\
\hline 33 & 07063000 & Black River at Poplar Bluff, Mo. & 1,245 & 1951 & 2011 & 61 & 0.651 & 46.52 & 15.01 & 9.74 & 5.22 \\
\hline 34 & 07064000 & Black River near Corning, Ark. & 1,750 & 1948 & 2011 & 57 & 0.633 & 46.56 & 14.64 & 9.19 & 5.33 \\
\hline 35 & 07068000 & Current River at Doniphan, Mo. & 2,038 & 1922 & 2011 & 61 & 0.734 & 46.62 & 18.70 & 13.69 & 4.96 \\
\hline 36 & 07069000 & Black River at Pocahontas, Ark. & 4,840 & 1951 & 2011 & 30 & 0.715 & 46.66 & 15.42 & 10.91 & 4.35 \\
\hline 37 & 07069500 & Spring River at Imboden, Ark. & 1,180 & 1937 & 2011 & 54 & 0.604 & 47.76 & 16.51 & 9.93 & 6.51 \\
\hline 38 & 07071500 & Eleven Point River near Bardley, Mo. & 793 & 1951 & 2011 & 61 & 0.788 & 45.56 & 13.34 & 10.47 & 2.82 \\
\hline 39 & 07072000 & Eleven Point River near Ravenden Springs, Ark. & 1,130 & 1930 & 2011 & 54 & 0.757 & 46.84 & 14.02 & 10.61 & 3.41 \\
\hline 40 & 07072500 & Black River at Black Rock, Ark. & 7,370 & 1948 & 2011 & 61 & 0.727 & 48.50 & 16.10 & 11.67 & 4.38 \\
\hline 41 & 07073000 & Strawberry River near Evening Shade, Ark. & 217 & 1940 & 1978 & 28 & 0.313 & 47.27 & 12.46 & 4.01 & 8.80 \\
\hline 42 & 07073500 & Piney Fork at Evening Shade, Ark. & 99.2 & 1940 & 1983 & 33 & 0.336 & 47.27 & 11.76 & 4.00 & 7.90 \\
\hline 43 & 07074000 & Strawberry River near Poughkeepsie, Ark. & 473 & 1937 & 2003 & 46 & 0.49 & 46.92 & 13.68 & 6.67 & 6.94 \\
\hline 44 & 07074500 & White River at Newport, Ark. & 19,900 & 1943 & 2011 & 61 & 0.718 & 47.58 & 15.12 & 10.83 & 4.25 \\
\hline 45 & 07075000 & Middle Fork of Little Red River at Shirley, Ark. & 302 & 1940 & 2011 & 36 & 0.242 & 50.60 & 20.27 & 4.88 & 15.29 \\
\hline 46 & 07075300 & South Fork of Little Red River at Clinton, Ark. & 148 & 1962 & 2011 & 43 & 0.301 & 51.33 & 21.95 & 6.55 & 15.22 \\
\hline 47 & 07076517 & Little Red River near Dewey, Ark. & 1,340 & 1997 & 2011 & 15 & 0.346 & 49.58 & 18.39 & 6.40 & 12.09 \\
\hline 48 & 07077000 & White River at DeValls Bluff, Ark. & 23,400 & 1950 & 2010 & 41 & 0.818 & 49.29 & 15.23 & 12.44 & 2.77 \\
\hline 49 & 07077380 & Cache River at Egypt, Ark. & 701 & 1965 & 2011 & 47 & 0.243 & 47.32 & 17.06 & 4.13 & 12.85 \\
\hline 50 & 07077500 & Cache River at Patterson, Ark. & 1,040 & 1928 & 2003 & 39 & 0.6 & 49.23 & 16.88 & 9.78 & 6.52 \\
\hline 51 & 07077555 & Cache River near Cotton Plant, Ark. & 1,170 & 1988 & 2010 & 23 & 0.481 & 49.49 & 16.19 & 7.73 & 8.34 \\
\hline 52 & 07077800 & White River at Clarendon, Ark. & 25,555 & 1929 & 1980 & 30 & 0.762 & 49.92 & 15.20 & 11.44 & 3.57 \\
\hline 53 & 07077950 & Big Creek at Poplar Grove, Ark. & 385 & 1971 & 1992 & 22 & 0.373 & 50.68 & 22.74 & 8.29 & 13.93 \\
\hline 54 & 07189000 & Elk River near Tiff City, Mo. & 851 & 1940 & 2011 & 61 & 0.436 & 43.10 & 12.76 & 5.54 & 7.17 \\
\hline 55 & 07191220 & Spavinaw Creek near Sycamore, Okla. & 132 & 1962 & 2011 & 50 & 0.511 & 44.23 & 11.71 & 5.97 & 5.71 \\
\hline 56 & 07194800 & Illinois River at Savoy, Ark. & 167 & 1980 & 2011 & 18 & 0.271 & 44.96 & 13.62 & 3.68 & 9.90 \\
\hline 57 & 07195000 & Osage Creek near Elm Springs, Ark. & 130 & 1951 & 2011 & 40 & 0.613 & 44.55 & 18.20 & 8.64 & 5.45 \\
\hline 58 & 07195430 & Illinois River South of Siloam Springs, Ark. & 575 & 1996 & 2011 & 16 & 0.49 & 45.09 & 15.08 & 7.31 & 7.61 \\
\hline 59 & 07195500 & Illinois River near Watts, Okla. & 630 & 1956 & 2011 & 56 & 0.453 & 45.09 & 13.89 & 6.26 & 7.56 \\
\hline 60 & 07195800 & Flint Creek at Springtown, Ark. & 14.2 & 1962 & 2011 & 50 & 0.509 & 44.92 & 14.47 & 7.47 & 7.21 \\
\hline 61 & 07195855 & Flint Creek near West Siloam Springs, Okla. & 59.8 & 1980 & 2011 & 32 & 0.546 & 44.97 & 10.96 & 5.95 & 4.95 \\
\hline 62 & 07196000 & Flint Creek near Kansas, Okla. & 116 & 1956 & 2011 & 49 & 0.509 & 45.12 & 13.65 & 6.97 & 6.73 \\
\hline
\end{tabular}


[mi², square miles; in., inches; GW, groundwater; note: precipitation values derived from PRISM data]

\begin{tabular}{|c|c|c|c|c|c|c|c|c|c|c|c|}
\hline \multirow[b]{2}{*}{$\begin{array}{c}\text { Map } \\
\text { number }\end{array}$} & \multirow[b]{2}{*}{$\begin{array}{l}\text { Station } \\
\text { number }\end{array}$} & \multirow[b]{2}{*}{ Station name } & \multirow{2}{*}{$\begin{array}{l}\text { Contributing } \\
\text { drainage } \\
\text { area } \\
\left(\mathrm{mi}^{2}\right)\end{array}$} & \multicolumn{3}{|c|}{ Period of measurements } & \multirow[b]{2}{*}{$\begin{array}{l}\text { Base- } \\
\text { flow } \\
\text { index }\end{array}$} & \multicolumn{4}{|c|}{ Mean annual } \\
\hline & & & & $\begin{array}{l}\text { Start } \\
\text { year }\end{array}$ & $\begin{array}{l}\text { End } \\
\text { year }\end{array}$ & $\begin{array}{l}\text { Number } \\
\text { of years } \\
\text { analyzed }\end{array}$ & & $\begin{array}{l}\text { Precip- } \\
\text { itation } \\
\text { (in.) }\end{array}$ & $\begin{array}{c}\text { Total } \\
\text { runoff } \\
\text { (in.) }\end{array}$ & $\begin{array}{c}\text { GW } \\
\text { runoff } \\
\text { (in.) }\end{array}$ & $\begin{array}{c}\text { Surface } \\
\text { runoff } \\
\text { (in.) }\end{array}$ \\
\hline 63 & 07196900 & Baron Fork at Dutch Mills, Ark. & 40.6 & 1959 & 2011 & 53 & 0.283 & 47.38 & 15.38 & 4.36 & 11.05 \\
\hline 64 & 07247000 & Poteau River at Cauthron, Ark. & 203 & 1975 & 2011 & 37 & 0.164 & 48.17 & 16.44 & 2.70 & 13.74 \\
\hline 65 & 07249400 & James Fork near Hackett, Ark. & 147 & 1959 & 2011 & 53 & 0.201 & 45.06 & 13.64 & 2.74 & 10.90 \\
\hline 66 & 07249500 & Cove Creek near Lee Creek, Ark. & 35.3 & 1951 & 1969 & 19 & 0.203 & 48.78 & 14.60 & 2.96 & 11.63 \\
\hline 67 & 07249985 & Lee Creek near Short, Okla. & 420 & 1931 & 2011 & 59 & 0.255 & 45.20 & 18.03 & 4.59 & 13.40 \\
\hline 68 & 07250000 & Lee Creek near Van Buren, Ark. & 426 & 1931 & 1991 & 41 & 0.26 & 45.20 & 16.78 & 4.33 & 12.34 \\
\hline 69 & 07251500 & Frog Bayou at Rudy, Ark. & 216 & 1951 & 2011 & 24 & 0.249 & 46.54 & 16.05 & 3.97 & 11.98 \\
\hline 70 & 07252000 & Mulberry River near Mulberry, Ark. & 373 & 1939 & 2011 & 46 & 0.302 & 48.09 & 19.42 & 5.87 & 13.57 \\
\hline 71 & 07256500 & Spadra Creek at Clarksville, Ark. & 61.1 & 1953 & 2010 & 20 & 0.267 & 47.17 & 16.48 & 4.42 & 12.13 \\
\hline 72 & 07257000 & Big Piney Creek near Dover, Ark. & 61.1 & 1951 & 1991 & 41 & 0.294 & 48.57 & 20.44 & 6.00 & 14.41 \\
\hline 73 & 07257006 & Big Piney Creek at Highway 164 near Dover, Ark. & 306 & 1993 & 2011 & 16 & 0.286 & 48.26 & 21.50 & 6.06 & 15.14 \\
\hline 74 & 07257500 & Illinois Bayou near Scottsville, Ark. & 241 & 1948 & 2011 & 31 & 0.244 & 47.39 & 20.74 & 5.04 & 15.61 \\
\hline 75 & 07258500 & Petit Jean River near Booneville, Ark. & 241 & 1939 & 2010 & 44 & 0.158 & 45.80 & 13.36 & 2.10 & 11.21 \\
\hline 76 & 07260000 & Dutch Creek at Waltreak, Ark. & 81.4 & 1946 & 2011 & 37 & 0.189 & 48.14 & 15.84 & 2.99 & 12.84 \\
\hline 77 & 07260500 & Petit Jean River at Danville, Ark. & 764 & 1947 & 2011 & 36 & 0.311 & 49.13 & 14.02 & 4.27 & 9.46 \\
\hline 78 & 07261000 & Cadron Creek near Guy, Ark. & 169 & 1955 & 2011 & 57 & 0.3 & 49.60 & 21.94 & 6.52 & 15.22 \\
\hline 79 & 07261500 & Fourche LaFave River Near Gravelly, Ark. & 410 & 1940 & 2011 & 55 & 0.224 & 50.08 & 17.97 & 4.00 & 13.84 \\
\hline 80 & 07263000 & South Fourche LaFave River near Hollis, Ark. & 210 & 1942 & 1986 & 36 & 0.158 & 49.74 & 18.41 & 2.87 & 15.28 \\
\hline 81 & 07264000 & Bayou Meto near Lonoke, Ark. & 207 & 1955 & 2011 & 57 & 0.28 & 48.36 & 19.51 & 5.42 & 13.93 \\
\hline 82 & 07280000 & Tallahatchie River near Lambert, Miss. & 1,980 & 1961 & 1979 & 19 & 0.606 & 53.97 & 19.41 & 11.88 & 7.72 \\
\hline 83 & 07287000 & Yazoo River at Greenwood, Miss. & 7,450 & 1908 & 1979 & 29 & 0.81 & 53.89 & 19.91 & 16.32 & 3.83 \\
\hline 84 & 07288500 & Big Sunflower River at Sunflower, Miss. & 767 & 1936 & 2010 & 37 & 0.377 & 54.33 & 18.99 & 7.21 & 11.92 \\
\hline 85 & 07290000 & Big Black River near Bovina, Miss. & 2,812 & 1937 & 2010 & 60 & 0.394 & 54.31 & 18.89 & 7.36 & 11.31 \\
\hline 86 & 07337900 & Glover River near Glover, Okla. & 320 & 1962 & 2012 & 51 & 0.174 & 50.06 & 20.72 & 3.63 & 17.21 \\
\hline 87 & 07338500 & Little River below Lukfata Creek, near Idabel, Okla. & 1,228 & 1971 & 2011 & 41 & 0.264 & 49.47 & 20.23 & 5.31 & 14.81 \\
\hline 88 & 07339000 & Mountain Fork near Eagletown, Okla. & 800 & 1970 & 2011 & 42 & 0.228 & 50.72 & 24.22 & 5.48 & 18.56 \\
\hline 89 & 07339500 & Rolling Fork near DeQueen, Ark. & 182 & 1949 & 1979 & 29 & 0.186 & 51.68 & 21.44 & 3.94 & 17.24 \\
\hline 90 & 07340000 & Little River near Horatio, Ark. & 2,660 & 1969 & 2011 & 43 & 0.306 & 50.92 & 20.75 & 6.32 & 14.33 \\
\hline 91 & 07340300 & Cossatot River near Vandervoort, Ark. & 89.6 & 1968 & 2011 & 44 & 0.253 & 55.77 & 28.46 & 7.16 & 21.13 \\
\hline 92 & 07340500 & Cossatot River near DeQueen, Ark. & 361 & 1939 & 1979 & 29 & 0.223 & 51.79 & 23.04 & 5.08 & 17.69 \\
\hline 93 & 07341000 & Saline River near Dierks, Ark. & 124 & 1939 & 2010 & 32 & 0.212 & 52.58 & 20.79 & 4.42 & 16.43 \\
\hline
\end{tabular}


Table 2. Estimated precipitation and runoff values for selected continuous-record streamflow-gaging stations within Arkansas and surrounding States. - Continued

[mi², square miles; in., inches; GW, groundwater; note: precipitation values derived from PRISM data]

\begin{tabular}{|c|c|c|c|c|c|c|c|c|c|c|c|}
\hline \multirow[b]{2}{*}{$\begin{array}{c}\text { Map } \\
\text { number }\end{array}$} & \multirow[b]{2}{*}{$\begin{array}{l}\text { Station } \\
\text { number }\end{array}$} & \multirow[b]{2}{*}{ Station name } & \multirow{2}{*}{$\begin{array}{l}\text { Contributing } \\
\text { drainage } \\
\text { area } \\
\left(\mathrm{mi}^{2}\right)\end{array}$} & \multicolumn{3}{|c|}{ Period of measurements } & \multirow[b]{2}{*}{$\begin{array}{l}\text { Base- } \\
\text { flow } \\
\text { index }\end{array}$} & \multicolumn{4}{|c|}{ Mean annual } \\
\hline & & & & $\begin{array}{l}\text { Start } \\
\text { year }\end{array}$ & $\begin{array}{l}\text { End } \\
\text { year }\end{array}$ & $\begin{array}{l}\text { Number } \\
\text { of years } \\
\text { analyzed }\end{array}$ & & $\begin{array}{l}\text { Precip- } \\
\text { itation } \\
\text { (in.) }\end{array}$ & $\begin{array}{c}\text { Total } \\
\text { runoff } \\
\text { (in.) }\end{array}$ & $\begin{array}{l}\text { GW } \\
\text { runoff } \\
\text { (in.) }\end{array}$ & $\begin{array}{c}\text { Surface } \\
\text { runoff } \\
\text { (in.) }\end{array}$ \\
\hline 94 & 07341200 & Saline River near Lockesburg, Ark. & 256 & 1975 & 2011 & 37 & 0.28 & 51.28 & 20.29 & 5.72 & 14.71 \\
\hline 95 & 07342500 & South Sulphur River near Cooper, Tex. & 527 & 1992 & 2011 & 20 & 0.103 & 43.78 & 9.65 & 0.98 & 8.54 \\
\hline 96 & 07343500 & White Oak Creek near Talco, Tex. & 494 & 1973 & 2011 & 39 & 0.081 & 44.96 & 14.04 & 1.14 & 12.88 \\
\hline 97 & 07346000 & Big Cypress Bayou near Jefferson, Tex. & 850 & 1958 & 2011 & 34 & 0.447 & 46.48 & 9.91 & 4.49 & 5.55 \\
\hline 98 & 07346070 & Little Cypress Bayou near Jefferson, Tex. & 675 & 1947 & 2011 & 61 & 0.43 & 46.88 & 10.51 & 4.50 & 5.97 \\
\hline 99 & 07348700 & Bayou Dorcheat near Springhill, La. & 605 & 1958 & 2011 & 54 & 0.291 & 50.07 & 13.40 & 3.89 & 9.48 \\
\hline 100 & 07349500 & Bodcau Bayou near Sarepta, La. & 546 & 1951 & 1991 & 41 & 0.454 & 50.10 & 13.84 & 6.25 & 7.51 \\
\hline 101 & 07356000 & Ouachita River near Mount Ida, Ark. & 414 & 1942 & 2011 & 61 & 0.273 & 53.22 & 22.98 & 6.25 & 16.64 \\
\hline 102 & 07356500 & South Fork Ouachita River at Mount Ida, Ark. & 61 & 1950 & 1969 & 19 & 0.21 & 55.19 & 20.06 & 4.19 & 15.74 \\
\hline 103 & 07359610 & Caddo River near Caddo Gap, Ark. & 136 & 1989 & 2011 & 23 & 0.342 & 56.36 & 26.82 & 9.14 & 17.58 \\
\hline 104 & 07359800 & Caddo River near Alpine, Ark. & 312 & 1939 & 1969 & 19 & 0.259 & 55.93 & 22.25 & 5.70 & 16.31 \\
\hline 105 & 07360000 & Ouachita River at Arkadelphia, Ark. & 2,311 & 1951 & 1976 & 26 & 0.368 & 53.07 & 20.04 & 7.29 & 12.53 \\
\hline 106 & 07361000 & Little Missouri River near Murfreesboro, Ark. & 380 & 1950 & 1976 & 26 & 0.211 & 53.38 & 22.03 & 4.59 & 17.16 \\
\hline 107 & 07361500 & Antoine River at Antoine, Ark. & 178 & 1955 & 2011 & 57 & 0.215 & 52.29 & 21.30 & 4.55 & 16.62 \\
\hline 108 & 07361600 & Little Missouri River near Boughton, Ark. & 1,079 & 1950 & 1976 & 26 & 0.257 & 52.00 & 18.72 & 4.77 & 13.79 \\
\hline 109 & 07362000 & Ouachita River at Camden, Ark. & 5,360 & 1929 & 2011 & 59 & 0.417 & 51.65 & 19.85 & 8.16 & 11.41 \\
\hline 110 & 07362100 & Smackover Creek near Smackover, Ark. & 385 & 1962 & 2011 & 50 & 0.25 & 51.26 & 14.65 & 3.68 & 11.03 \\
\hline 111 & 07362500 & Moro Creek near Fordyce, Ark. & 240 & 1952 & 2012 & 43 & 0.172 & 52.47 & 14.32 & 2.50 & 12.02 \\
\hline 112 & 07363000 & Saline River at Benton, Ark. & 550 & 1951 & 2011 & 39 & 0.238 & 52.82 & 19.17 & 4.59 & 14.69 \\
\hline 113 & 07363200 & Saline River near Sheridan, Ark. & 1,120 & 1971 & 2011 & 21 & 0.3 & 52.10 & 19.27 & 5.70 & 13.31 \\
\hline 114 & 07363300 & Hurricane Creek near Sheridan, Ark. & 204 & 1962 & 1994 & 33 & 0.244 & 52.05 & 15.43 & 3.72 & 11.53 \\
\hline 115 & 07363400 & Hurricane Creek below Sheridan, Ark. & 261 & 1996 & 2011 & 16 & 0.211 & 51.69 & 16.85 & 3.49 & 13.04 \\
\hline 116 & 07363500 & Saline River near Rye, Ark. & 2,100 & 1938 & 2011 & 60 & 0.364 & 53.13 & 16.75 & 6.06 & 10.59 \\
\hline 117 & 07364133 & Bayou Bartholomew at Garrett Bridge, Ark. & 380 & 1988 & 2011 & 24 & 0.355 & 50.86 & 18.02 & 6.36 & 11.56 \\
\hline 118 & 07364150 & Bayou Bartholomew near McGehee, Ark. & 576 & 1939 & 2011 & 61 & 0.457 & 51.66 & 15.98 & 7.28 & 8.64 \\
\hline 119 & 07364200 & Bayou Bartholomew near Jones, La. & 1,187 & 1983 & 2011 & 29 & 0.67 & 53.70 & 15.69 & 10.52 & 5.18 \\
\hline 120 & 07364300 & Chemin-A-Haut Bayou near Beekman, La. & 271 & 1956 & 1978 & 23 & 0.151 & 54.31 & 14.17 & 2.22 & 12.49 \\
\hline 121 & 07364700 & Bayou De Loutre near Laran, La. & 141 & 1956 & 1976 & 21 & 0.291 & 53.19 & 18.25 & 5.16 & 12.57 \\
\hline 122 & 07365800 & Cornie Bayou near Three Creeks, La. & 180 & 1957 & 1986 & 30 & 0.212 & 52.25 & 13.58 & 2.83 & 10.50 \\
\hline 123 & 07366200 & Little Corney Bayou near Lillie, La. & 208 & 1956 & 2011 & 54 & 0.244 & 53.29 & 13.50 & 3.24 & 10.04 \\
\hline
\end{tabular}


[mi², square miles; in., inches; GW, groundwater; note: precipitation values derived from PRISM data]

\begin{tabular}{|c|c|c|c|c|c|c|c|c|c|c|}
\hline \multirow[b]{2}{*}{$\begin{array}{c}\text { Map } \\
\text { number }\end{array}$} & \multirow[b]{2}{*}{$\begin{array}{l}\text { Station } \\
\text { number }\end{array}$} & \multirow[b]{2}{*}{ Station name } & \multicolumn{4}{|c|}{ Mean wet season } & \multicolumn{4}{|c|}{ Mean dry season } \\
\hline & & & $\begin{array}{l}\text { Precip- } \\
\text { itation } \\
\text { (in.) }\end{array}$ & $\begin{array}{c}\text { Total } \\
\text { runoff } \\
\text { (in.) }\end{array}$ & $\begin{array}{c}\text { GW } \\
\text { runoff } \\
\text { (in.) }\end{array}$ & $\begin{array}{c}\text { Surface } \\
\text { runoff } \\
\text { (in.) }\end{array}$ & $\begin{array}{c}\text { Precip- } \\
\text { itation } \\
\text { (in.) }\end{array}$ & $\begin{array}{c}\text { Total } \\
\text { runoff } \\
\text { (in.) }\end{array}$ & $\begin{array}{c}\text { GW } \\
\text { runoff } \\
\text { (in.) }\end{array}$ & $\begin{array}{c}\text { Surface } \\
\text { runoff } \\
\text { (in.) }\end{array}$ \\
\hline 1 & 07026040 & Obion River at Highway 51 near Obion, Tenn. & 28.16 & 15.36 & 5.84 & 9.52 & 22.61 & 5.57 & 2.12 & 3.45 \\
\hline 2 & 07026500 & Reelfoot Creek near Samburg, Tenn. & 28.20 & 11.50 & 0.90 & 10.60 & 22.40 & 3.36 & 0.26 & 3.10 \\
\hline 3 & 07032200 & Nonconnah Creek near Germantown, Tenn. & 30.37 & 16.66 & 0.48 & 16.18 & 22.51 & 4.95 & 0.14 & 4.81 \\
\hline 4 & 07035000 & Little St. Francis River at Fredericktown, Mo. & 22.23 & 13.72 & 3.50 & 10.22 & 21.52 & 4.62 & 1.18 & 3.45 \\
\hline 5 & 07035500 & Barnes Creek near Fredericktown, Mo. & 22.09 & 12.51 & 1.96 & 10.55 & 21.46 & 3.86 & 0.61 & 3.26 \\
\hline 6 & 07035800 & St. Francis River near Mill Creek, Mo. & 22.31 & 12.60 & 3.31 & 9.28 & 21.84 & 3.02 & 0.79 & 2.23 \\
\hline 7 & 07036100 & St. Francis River near Saco, Mo. & 22.84 & 14.51 & 3.74 & 10.76 & 21.88 & 4.60 & 1.19 & 3.41 \\
\hline 8 & 07037000 & Big Creek at Des Arc, Mo. & 23.12 & 14.34 & 5.13 & 9.21 & 21.99 & 5.47 & 1.96 & 3.51 \\
\hline 9 & 07037500 & St. Francis River near Patterson, Mo. & 23.77 & 12.91 & 3.92 & 8.98 & 22.00 & 3.45 & 1.05 & 2.40 \\
\hline 10 & 07037700 & Clark Creek near Piedmont, Mo. & 23.68 & 10.24 & 3.28 & 6.96 & 22.07 & 3.03 & 0.97 & 2.06 \\
\hline 11 & 07039500 & St. Francis River at Wappapello, Mo. & 25.23 & 12.74 & 6.23 & 6.51 & 22.03 & 3.41 & 1.67 & 1.74 \\
\hline 12 & 07040100 & St. Francis River at St. Francis, Ark. & 26.00 & 12.59 & 6.70 & 5.89 & 20.73 & 3.61 & 1.92 & 1.69 \\
\hline 13 & 07040450 & St. Francis River at Lake City, Ark. & 26.75 & 12.41 & 8.03 & 4.38 & 21.54 & 3.83 & 2.48 & 1.35 \\
\hline 14 & 07043500 & Little River Ditch No. 1 near Morehouse, Mo. & 25.18 & 12.22 & 4.53 & 7.68 & 21.32 & 4.15 & 1.54 & 2.61 \\
\hline 15 & 07047600 & Tyronza River near Tyronza, Ark. & 27.95 & 13.62 & 3.53 & 10.10 & 21.33 & 5.34 & 1.38 & 3.96 \\
\hline 16 & 07047942 & LAnguille River near Colt, Ark. & 28.25 & 13.13 & 4.45 & 8.68 & 21.42 & 5.08 & 1.72 & 3.36 \\
\hline 17 & 07047950 & LAnguille River at Palestine, Ark. & 28.64 & 13.94 & 5.06 & 8.88 & 21.53 & 4.32 & 1.57 & 2.75 \\
\hline 18 & 07048000 & West Fork White River at Greenland, Ark. & 22.20 & 12.90 & 3.03 & 9.87 & 23.46 & 3.69 & 0.87 & 2.82 \\
\hline 19 & 07048600 & White River near Fayetteville, Ark. & 21.48 & 14.34 & 3.89 & 10.46 & 23.32 & 4.49 & 1.22 & 3.27 \\
\hline 20 & 07049000 & War Eagle Creek near Hindsville, Ark. & 21.54 & 11.81 & 3.27 & 8.54 & 23.14 & 3.49 & 0.97 & 2.52 \\
\hline 21 & 07050500 & Kings River near Berryville, Ark. & 21.19 & 11.21 & 3.46 & 7.75 & 22.83 & 3.72 & 1.15 & 2.57 \\
\hline 22 & 07052500 & James River at Galena, Mo. & 20.40 & 9.41 & 4.18 & 5.23 & 23.09 & 4.23 & 1.88 & 2.35 \\
\hline 23 & 07053250 & Yocum Creek near Oak Grove, Ark. & 20.94 & 8.00 & 3.42 & 4.57 & 22.55 & 4.20 & 1.80 & 2.40 \\
\hline 24 & 07055646 & Buffalo River near Boxley, Ark. & 23.46 & 19.64 & 4.63 & 15.00 & 22.72 & 4.72 & 1.11 & 3.61 \\
\hline 25 & 07055875 & Richland Creek near Witts Spring, Ark. & 25.25 & 18.47 & 4.88 & 13.59 & 23.62 & 5.07 & 1.34 & 3.74 \\
\hline 26 & 07056000 & Buffalo River near St. Joe, Ark. & 22.69 & 13.45 & 4.45 & 9.00 & 21.33 & 3.62 & 1.20 & 2.42 \\
\hline 27 & 07057000 & Buffalo River near Rush, Ark. & 22.70 & 11.81 & 3.92 & 7.89 & 21.73 & 2.82 & 0.93 & 1.88 \\
\hline 28 & 07057500 & North Fork River near Tecumseh, Mo. & 21.73 & 11.32 & 8.17 & 3.15 & 21.59 & 6.23 & 4.50 & 1.73 \\
\hline 29 & 07060500 & White River at Calico Rock, Ark. & 23.34 & 8.09 & 4.02 & 4.07 & 22.10 & 5.49 & 2.73 & 2.76 \\
\hline 30 & 07060710 & North Sylamore Creek near Fifty Six, Ark. & 23.54 & 8.83 & 2.44 & 6.39 & 22.13 & 2.39 & 0.66 & 1.73 \\
\hline 31 & 07061000 & White River at Batesville, Ark. & 25.29 & 9.67 & 5.30 & 4.37 & 22.44 & 6.19 & 3.39 & 2.80 \\
\hline
\end{tabular}


Table 2. Estimated precipitation and runoff values for selected continuous-record streamflow-gaging stations within Arkansas and surrounding States.-Continued

[mi², square miles; in., inches; GW, groundwater; note: precipitation values derived from PRISM data]

\begin{tabular}{|c|c|c|c|c|c|c|c|c|c|c|}
\hline \multirow[b]{2}{*}{$\begin{array}{c}\text { Map } \\
\text { number }\end{array}$} & \multirow[b]{2}{*}{$\begin{array}{l}\text { Station } \\
\text { number }\end{array}$} & \multirow[b]{2}{*}{ Station name } & \multicolumn{4}{|c|}{ Mean wet season } & \multicolumn{4}{|c|}{ Mean dry season } \\
\hline & & & $\begin{array}{l}\text { Precip- } \\
\text { itation } \\
\text { (in.) }\end{array}$ & $\begin{array}{c}\text { Total } \\
\text { runoff } \\
\text { (in.) }\end{array}$ & $\begin{array}{c}\text { GW } \\
\text { runoff } \\
\text { (in.) }\end{array}$ & $\begin{array}{c}\text { Surface } \\
\text { runoff } \\
\text { (in.) }\end{array}$ & $\begin{array}{l}\text { Precip- } \\
\text { itation } \\
\text { (in.) }\end{array}$ & $\begin{array}{c}\text { Total } \\
\text { runoff } \\
\text { (in.) }\end{array}$ & $\begin{array}{c}\text { GW } \\
\text { runoff } \\
\text { (in.) }\end{array}$ & $\begin{array}{c}\text { Surface } \\
\text { runoff } \\
\text { (in.) }\end{array}$ \\
\hline 32 & 07061500 & Black River near Annapolis, Mo. & 22.94 & 11.82 & 5.55 & 6.28 & 22.13 & 4.99 & 2.34 & 2.65 \\
\hline 33 & 07063000 & Black River at Poplar Bluff, Mo. & 24.95 & 10.14 & 6.60 & 3.54 & 21.51 & 4.82 & 3.14 & 1.68 \\
\hline 34 & 07064000 & Black River near Corning, Ark. & 25.91 & 10.44 & 6.61 & 3.83 & 20.59 & 4.08 & 2.58 & 1.50 \\
\hline 35 & 07068000 & Current River at Doniphan, Mo. & 25.18 & 11.97 & 8.79 & 3.19 & 21.34 & 6.67 & 4.90 & 1.77 \\
\hline 36 & 07069000 & Black River at Pocahontas, Ark. & 25.44 & 10.69 & 7.65 & 3.05 & 21.13 & 4.57 & 3.27 & 1.30 \\
\hline 37 & 07069500 & Spring River at Imboden, Ark. & 25.93 & 11.68 & 7.06 & 4.63 & 21.82 & 4.76 & 2.87 & 1.88 \\
\hline 38 & 07071500 & Eleven Point River near Bardley, Mo. & 23.72 & 8.49 & 6.69 & 1.80 & 21.82 & 4.80 & 3.78 & 1.02 \\
\hline 39 & 07072000 & Eleven Point River near Ravenden Springs, Ark. & 25.43 & 9.15 & 6.93 & 2.22 & 21.39 & 4.86 & 3.68 & 1.18 \\
\hline 40 & 07072500 & Black River at Black Rock, Ark. & 26.36 & 11.24 & 8.17 & 3.07 & 22.12 & 4.81 & 3.49 & 1.31 \\
\hline 41 & 07073000 & Strawberry River near Evening Shade, Ark. & 24.85 & 9.98 & 3.12 & 6.86 & 22.42 & 2.83 & 0.89 & 1.94 \\
\hline 42 & 07073500 & Piney Fork at Evening Shade, Ark. & 24.85 & 9.29 & 3.12 & 6.17 & 22.42 & 2.60 & 0.87 & 1.73 \\
\hline 43 & 07074000 & Strawberry River near Poughkeepsie, Ark. & 24.80 & 10.43 & 5.11 & 5.32 & 22.10 & 3.18 & 1.56 & 1.62 \\
\hline 44 & 07074500 & White River at Newport, Ark. & 25.67 & 9.98 & 7.16 & 2.81 & 21.84 & 5.10 & 3.66 & 1.44 \\
\hline 45 & 07075000 & Middle Fork of Little Red River at Shirley, Ark. & 26.69 & 16.07 & 3.89 & 12.18 & 23.90 & 4.11 & 0.99 & 3.11 \\
\hline 46 & 07075300 & South Fork of Little Red River at Clinton, Ark. & 27.28 & 17.47 & 5.26 & 12.21 & 24.01 & 4.30 & 1.30 & 3.01 \\
\hline 47 & 07076517 & Little Red River near Dewey, Ark. & 26.83 & 11.63 & 4.02 & 7.60 & 22.70 & 6.87 & 2.38 & 4.49 \\
\hline 48 & 07077000 & White River at DeValls Bluff, Ark. & 28.02 & 10.09 & 8.26 & 1.84 & 21.27 & 5.11 & 4.18 & 0.93 \\
\hline 49 & 07077380 & Cache River at Egypt, Ark. & 25.99 & 11.98 & 2.91 & 9.07 & 21.32 & 5.00 & 1.21 & 3.78 \\
\hline 50 & 07077500 & Cache River at Patterson, Ark. & 27.49 & 12.02 & 7.21 & 4.81 & 21.74 & 4.27 & 2.56 & 1.71 \\
\hline 51 & 07077555 & Cache River near Cotton Plant, Ark. & 27.99 & 11.62 & 5.59 & 6.03 & 21.49 & 4.46 & 2.14 & 2.31 \\
\hline 52 & 07077800 & White River at Clarendon, Ark. & 28.28 & 10.25 & 7.81 & 2.44 & 21.63 & 4.77 & 3.63 & 1.14 \\
\hline 53 & 07077950 & Big Creek at Poplar Grove, Ark. & 29.14 & 17.21 & 6.42 & 10.79 & 21.54 & 5.02 & 1.87 & 3.15 \\
\hline 54 & 07189000 & Elk River near Tiff City, Mo. & 19.77 & 8.83 & 3.85 & 4.98 & 23.35 & 3.88 & 1.69 & 2.19 \\
\hline 55 & 07191220 & Spavinaw Creek near Sycamore, Okla. & 20.75 & 7.72 & 3.95 & 3.78 & 23.46 & 3.95 & 2.02 & 1.93 \\
\hline 56 & 07194800 & Illinois River at Savoy, Ark. & 21.53 & 9.50 & 2.57 & 6.92 & 23.43 & 4.09 & 1.11 & 2.98 \\
\hline 57 & 07195000 & Osage Creek near Elm Springs, Ark. & 21.33 & 8.34 & 5.12 & 3.23 & 23.21 & 5.75 & 3.52 & 2.22 \\
\hline 58 & 07195430 & Illinois River South of Siloam Springs, Ark. & 21.39 & 9.69 & 4.75 & 4.94 & 23.68 & 5.22 & 2.56 & 2.66 \\
\hline 59 & 07195500 & Illinois River near Watts, Okla. & 21.40 & 9.08 & 4.11 & 4.97 & 23.67 & 4.73 & 2.14 & 2.59 \\
\hline 60 & 07195800 & Flint Creek at Springtown, Ark. & 21.41 & 8.86 & 4.51 & 4.35 & 23.53 & 5.82 & 2.96 & 2.86 \\
\hline 61 & 07195855 & Flint Creek near West Siloam Springs, Okla. & 21.19 & 7.03 & 3.84 & 3.19 & 23.78 & 3.87 & 2.12 & 1.76 \\
\hline 62 & 07196000 & Flint Creek near Kansas, Okla. & 21.19 & 8.72 & 4.44 & 4.28 & 23.87 & 4.98 & 2.54 & 2.45 \\
\hline
\end{tabular}


[mi², square miles; in., inches; GW, groundwater; note: precipitation values derived from PRISM data]

\begin{tabular}{|c|c|c|c|c|c|c|c|c|c|c|}
\hline \multirow[b]{2}{*}{$\begin{array}{c}\text { Map } \\
\text { number }\end{array}$} & \multirow[b]{2}{*}{$\begin{array}{l}\text { Station } \\
\text { number }\end{array}$} & \multirow[b]{2}{*}{ Station name } & \multicolumn{4}{|c|}{ Mean wet season } & \multicolumn{4}{|c|}{ Mean dry season } \\
\hline & & & $\begin{array}{c}\text { Precip- } \\
\text { itation } \\
\text { (in.) }\end{array}$ & $\begin{array}{c}\text { Total } \\
\text { runoff } \\
\text { (in.) }\end{array}$ & $\begin{array}{c}\text { GW } \\
\text { runoff } \\
\text { (in.) }\end{array}$ & $\begin{array}{c}\text { Surface } \\
\text { runoff } \\
\text { (in.) }\end{array}$ & $\begin{array}{c}\text { Precip- } \\
\text { itation } \\
\text { (in.) }\end{array}$ & $\begin{array}{c}\text { Total } \\
\text { runoff } \\
\text { (in.) }\end{array}$ & $\begin{array}{c}\text { GW } \\
\text { runoff } \\
\text { (in.) }\end{array}$ & $\begin{array}{c}\text { Surface } \\
\text { runoff } \\
\text { (in.) }\end{array}$ \\
\hline 63 & 07196900 & Baron Fork at Dutch Mills, Ark. & 22.96 & 10.68 & 3.02 & 7.66 & 24.45 & 4.72 & 1.34 & 3.39 \\
\hline 64 & 07247000 & Poteau River at Cauthron, Ark. & 24.66 & 12.48 & 2.05 & 10.44 & 23.48 & 3.95 & 0.65 & 3.30 \\
\hline 65 & 07249400 & James Fork near Hackett, Ark. & 22.79 & 10.47 & 2.10 & 8.37 & 22.22 & 3.17 & 0.64 & 2.53 \\
\hline 66 & 07249500 & Cove Creek near Lee Creek, Ark. & 23.82 & 11.40 & 2.32 & 9.09 & 25.02 & 3.19 & 0.65 & 2.54 \\
\hline 67 & 07249985 & Lee Creek near Short, Okla. & 22.41 & 13.76 & 3.51 & 10.25 & 22.78 & 4.22 & 1.08 & 3.15 \\
\hline 68 & 07250000 & Lee Creek near Van Buren, Ark. & 22.41 & 12.72 & 3.31 & 9.42 & 22.78 & 3.95 & 1.03 & 2.92 \\
\hline 69 & 07251500 & Frog Bayou at Rudy, Ark. & 23.11 & 12.87 & 3.20 & 9.66 & 23.33 & 3.09 & 0.77 & 2.32 \\
\hline 70 & 07252000 & Mulberry River near Mulberry, Ark. & 24.11 & 15.27 & 4.61 & 10.66 & 23.78 & 4.17 & 1.26 & 2.91 \\
\hline 71 & 07256500 & Spadra Creek at Clarksville, Ark. & 24.41 & 13.35 & 3.57 & 9.79 & 22.72 & 3.20 & 0.85 & 2.34 \\
\hline 72 & 07257000 & Big Piney Creek near Dover, Ark. & 25.38 & 16.50 & 4.85 & 11.65 & 23.21 & 3.90 & 1.15 & 2.75 \\
\hline 73 & 07257006 & Big Piney Creek at Highway 164 near Dover, Ark. & 25.23 & 16.83 & 4.81 & 12.02 & 22.82 & 4.37 & 1.25 & 3.12 \\
\hline 74 & 07257500 & Illinois Bayou near Scottsville, Ark. & 24.62 & 17.02 & 4.15 & 12.87 & 22.57 & 3.63 & 0.89 & 2.74 \\
\hline 75 & 07258500 & Petit Jean River near Booneville, Ark. & 23.43 & 10.61 & 1.68 & 8.93 & 22.17 & 2.70 & 0.43 & 2.28 \\
\hline 76 & 07260000 & Dutch Creek at Waltreak, Ark. & 25.26 & 12.61 & 2.38 & 10.23 & 22.84 & 3.22 & 0.61 & 2.61 \\
\hline 77 & 07260500 & Petit Jean River at Danville, Ark. & 25.91 & 10.30 & 3.20 & 7.10 & 23.25 & 3.43 & 1.07 & 2.36 \\
\hline 78 & 07261000 & Cadron Creek near Guy, Ark. & 26.38 & 17.61 & 5.28 & 12.33 & 23.18 & 4.13 & 1.24 & 2.89 \\
\hline 79 & 07261500 & Fourche LaFave River Near Gravelly, Ark. & 26.28 & 13.99 & 3.13 & 10.85 & 23.72 & 3.85 & 0.86 & 2.99 \\
\hline 80 & 07263000 & South Fourche LaFave River near Hollis, Ark. & 26.39 & 14.57 & 2.30 & 12.27 & 23.32 & 3.57 & 0.56 & 3.01 \\
\hline 81 & 07264000 & Bayou Meto near Lonoke, Ark. & 27.14 & 15.73 & 4.41 & 11.33 & 21.24 & 3.61 & 1.01 & 2.60 \\
\hline 82 & 07280000 & Tallahatchie River near Lambert, Miss. & 31.16 & 14.43 & 8.74 & 5.68 & 22.81 & 5.17 & 3.13 & 2.04 \\
\hline 83 & 07287000 & Yazoo River at Greenwood, Miss. & 31.19 & 12.47 & 10.10 & 2.37 & 22.70 & 7.68 & 6.22 & 1.46 \\
\hline 84 & 07288500 & Big Sunflower River at Sunflower, Miss. & 31.46 & 14.25 & 5.37 & 8.88 & 22.85 & 4.89 & 1.84 & 3.04 \\
\hline 85 & 07290000 & Big Black River near Bovina, Miss. & 31.67 & 15.60 & 6.15 & 9.45 & 22.65 & 3.07 & 1.21 & 1.86 \\
\hline 86 & 07337900 & Glover River near Glover, Okla. & 25.79 & 14.99 & 2.61 & 12.38 & 24.22 & 5.85 & 1.02 & 4.83 \\
\hline 87 & 07338500 & Little River below Lukfata Creek, near Idabel, Okla. & 25.97 & 14.26 & 3.77 & 10.50 & 23.47 & 5.86 & 1.55 & 4.31 \\
\hline 88 & 07339000 & Mountain Fork near Eagletown, Okla. & 26.50 & 15.88 & 3.62 & 12.26 & 24.13 & 8.16 & 1.86 & 6.30 \\
\hline 89 & 07339500 & Rolling Fork near DeQueen, Ark. & 27.74 & 16.12 & 3.00 & 13.12 & 23.99 & 5.06 & 0.94 & 4.12 \\
\hline 90 & 07340000 & Little River near Horatio, Ark. & 27.33 & 14.47 & 4.43 & 10.04 & 23.54 & 6.18 & 1.89 & 4.29 \\
\hline 91 & 07340300 & Cossatot River near Vandervoort, Ark. & 29.16 & 20.11 & 5.09 & 15.02 & 26.58 & 8.18 & 2.07 & 6.11 \\
\hline 92 & 07340500 & Cossatot River near DeQueen, Ark. & 27.77 & 17.76 & 3.96 & 13.80 & 23.96 & 5.00 & 1.12 & 3.89 \\
\hline 93 & 07341000 & Saline River near Dierks, Ark. & 28.04 & 16.32 & 3.46 & 12.86 & 24.53 & 4.53 & 0.96 & 3.57 \\
\hline
\end{tabular}


Table 2. Estimated precipitation and runoff values for selected continuous-record streamflow-gaging stations within Arkansas and surrounding States.-Continued

[ $\mathrm{mi}^{2}$, square miles; in., inches; GW, groundwater; note: precipitation values derived from PRISM data]

\begin{tabular}{|c|c|c|c|c|c|c|c|c|c|c|}
\hline \multirow[b]{2}{*}{$\begin{array}{c}\text { Map } \\
\text { number }\end{array}$} & \multirow[b]{2}{*}{$\begin{array}{l}\text { Station } \\
\text { number }\end{array}$} & \multirow[b]{2}{*}{ Station name } & \multicolumn{4}{|c|}{ Mean wet season } & \multicolumn{4}{|c|}{ Mean dry season } \\
\hline & & & $\begin{array}{l}\text { Precip- } \\
\text { itation } \\
\text { (in.) }\end{array}$ & $\begin{array}{c}\text { Total } \\
\text { runoff } \\
\text { (in.) }\end{array}$ & $\begin{array}{c}\text { GW } \\
\text { runoff } \\
\text { (in.) }\end{array}$ & $\begin{array}{c}\text { Surface } \\
\text { runoff } \\
\text { (in.) }\end{array}$ & $\begin{array}{l}\text { Precip- } \\
\text { itation } \\
\text { (in.) }\end{array}$ & $\begin{array}{c}\text { Total } \\
\text { runoff } \\
\text { (in.) }\end{array}$ & $\begin{array}{c}\text { GW } \\
\text { runoff } \\
\text { (in.) }\end{array}$ & $\begin{array}{c}\text { Surface } \\
\text { runoff } \\
\text { (in.) }\end{array}$ \\
\hline 94 & 07341200 & Saline River near Lockesburg, Ark. & 27.49 & 15.36 & 4.30 & 11.06 & 23.79 & 5.07 & 1.42 & 3.65 \\
\hline 95 & 07342500 & South Sulphur River near Cooper, Tex. & 22.68 & 7.31 & 0.75 & 6.56 & 21.10 & 2.21 & 0.23 & 1.99 \\
\hline 96 & 07343500 & White Oak Creek near Talco, Tex. & 23.34 & 9.80 & 0.79 & 9.01 & 21.57 & 4.22 & 0.34 & 3.88 \\
\hline 97 & 07346000 & Big Cypress Bayou near Jefferson, Tex. & 25.20 & 7.34 & 3.28 & 4.06 & 21.27 & 2.70 & 1.21 & 1.49 \\
\hline 98 & 07346070 & Little Cypress Bayou near Jefferson, Tex. & 25.35 & 8.42 & 3.62 & 4.80 & 21.51 & 2.05 & 0.88 & 1.17 \\
\hline 99 & 07348700 & Bayou Dorcheat near Springhill, La. & 27.27 & 11.01 & 3.20 & 7.80 & 22.75 & 2.36 & 0.69 & 1.68 \\
\hline 100 & 07349500 & Bodcau Bayou near Sarepta, La. & 27.30 & 11.23 & 5.10 & 6.13 & 22.74 & 2.53 & 1.15 & 1.38 \\
\hline 101 & 07356000 & Ouachita River near Mount Ida, Ark. & 28.12 & 16.90 & 4.61 & 12.29 & 25.02 & 5.99 & 1.64 & 4.36 \\
\hline 102 & 07356500 & South Fork Ouachita River at Mount Ida, Ark. & 29.29 & 15.99 & 3.36 & 12.63 & 25.90 & 3.94 & 0.83 & 3.12 \\
\hline 103 & 07359610 & Caddo River near Caddo Gap, Ark. & 30.07 & 18.21 & 6.23 & 11.98 & 26.16 & 8.51 & 2.91 & 5.60 \\
\hline 104 & 07359800 & Caddo River near Alpine, Ark. & 29.76 & 18.01 & 4.67 & 13.35 & 26.20 & 3.99 & 1.03 & 2.96 \\
\hline 105 & 07360000 & Ouachita River at Arkadelphia, Ark. & 28.64 & 13.47 & 4.96 & 8.52 & 24.41 & 6.35 & 2.34 & 4.01 \\
\hline 106 & 07361000 & Little Missouri River near Murfreesboro, Ark. & 28.61 & 13.60 & 2.87 & 10.73 & 24.74 & 8.14 & 1.72 & 6.42 \\
\hline 107 & 07361500 & Antoine River at Antoine, Ark. & 27.95 & 16.41 & 3.53 & 12.88 & 24.22 & 4.77 & 1.02 & 3.74 \\
\hline 108 & 07361600 & Little Missouri River near Boughton, Ark. & 28.17 & 13.69 & 3.52 & 10.17 & 23.79 & 4.87 & 1.25 & 3.62 \\
\hline 109 & 07362000 & Ouachita River at Camden, Ark. & 28.10 & 14.27 & 5.95 & 8.32 & 23.53 & 5.29 & 2.21 & 3.09 \\
\hline 110 & 07362100 & Smackover Creek near Smackover, Ark. & 28.29 & 11.54 & 2.89 & 8.66 & 22.94 & 3.16 & 0.79 & 2.37 \\
\hline 111 & 07362500 & Moro Creek near Fordyce, Ark. & 29.51 & 12.30 & 2.12 & 10.19 & 22.95 & 2.22 & 0.38 & 1.84 \\
\hline 112 & 07363000 & Saline River at Benton, Ark. & 27.96 & 15.17 & 3.61 & 11.56 & 24.84 & 4.11 & 0.98 & 3.13 \\
\hline 113 & 07363200 & Saline River near Sheridan, Ark. & 29.06 & 14.77 & 4.43 & 10.34 & 23.04 & 4.24 & 1.27 & 2.97 \\
\hline 114 & 07363300 & Hurricane Creek near Sheridan, Ark. & 28.94 & 13.09 & 3.19 & 9.90 & 23.07 & 2.15 & 0.53 & 1.63 \\
\hline 115 & 07363400 & Hurricane Creek below Sheridan, Ark. & 28.93 & 13.29 & 2.80 & 10.48 & 22.76 & 3.25 & 0.68 & 2.56 \\
\hline 116 & 07363500 & Saline River near Rye, Ark. & 29.99 & 14.00 & 5.10 & 8.91 & 23.15 & 2.65 & 0.97 & 1.69 \\
\hline 117 & 07364133 & Bayou Bartholomew at Garrett Bridge, Ark. & 29.14 & 14.04 & 4.98 & 9.06 & 21.71 & 3.89 & 1.38 & 2.51 \\
\hline 118 & 07364150 & Bayou Bartholomew near McGehee, Ark. & 30.01 & 12.77 & 5.84 & 6.93 & 21.63 & 3.15 & 1.44 & 1.71 \\
\hline 119 & 07364200 & Bayou Bartholomew near Jones, La. & 30.82 & 12.55 & 8.41 & 4.14 & 22.88 & 3.16 & 2.12 & 1.04 \\
\hline 120 & 07364300 & Chemin-A-Haut Bayou near Beekman, La. & 30.95 & 12.36 & 1.87 & 10.49 & 23.35 & 2.35 & 0.35 & 1.99 \\
\hline 121 & 07364700 & Bayou De Loutre near Laran, La. & 29.95 & 13.14 & 3.82 & 9.32 & 23.24 & 4.59 & 1.34 & 3.25 \\
\hline 122 & 07365800 & Cornie Bayou near Three Creeks, La. & 28.87 & 10.66 & 2.26 & 8.40 & 23.36 & 2.67 & 0.57 & 2.10 \\
\hline 123 & 07366200 & Little Corney Bayou near Lillie, La. & 29.95 & 10.58 & 2.58 & 8.00 & 23.33 & 2.70 & 0.66 & 2.04 \\
\hline
\end{tabular}


Table 3. Annual and seasonal statistics for precipitation and runoff by physiographic sections in Arkansas, $1951-2011$.

[Units, inches; Min, minimum; Max, maximum; Std dev, standard deviation; Wet season: December, January, February, March, April, May; Dry season: June, July, August, September, October, November]

\begin{tabular}{|c|c|c|c|c|c|c|c|c|c|c|c|c|c|c|c|c|}
\hline \multirow{2}{*}{ Season } & \multicolumn{4}{|c|}{ Statewide } & \multicolumn{4}{|c|}{ Springfield-Salem Plateaus } & \multicolumn{4}{|c|}{ Boston Mountains } & \multicolumn{4}{|c|}{ Arkansas Valley } \\
\hline & Min & Max & Mean & Std dev & Min & Max & Mean & Std dev & Min & Max & Mean & Std dev & Min & Max & Mean & Std dev \\
\hline \multicolumn{17}{|c|}{ Precipitation } \\
\hline Annual & 42.9 & 64.7 & 49.8 & 3.0 & 43.0 & 50.4 & 45.5 & 1.4 & 44.1 & 56.3 & 49.2 & 2.4 & 42.9 & 58.2 & 48.2 & 2.1 \\
\hline Wet season & 20.6 & 34.1 & 26.9 & 2.4 & 20.6 & 26.4 & 23.2 & 1.6 & 21.8 & 28.3 & 25.1 & 1.6 & 21.4 & 29.7 & 25.3 & 1.7 \\
\hline Dry season & 19.7 & 31.2 & 22.9 & 1.5 & 21.0 & 25.4 & 22.3 & 0.7 & 21.2 & 28.1 & 24.1 & 1.1 & 21.4 & 28.4 & 22.9 & 0.7 \\
\hline \multicolumn{17}{|c|}{ Total runoff } \\
\hline Annual & 12.3 & 27.1 & 17.8 & 2.5 & 12.3 & 19.1 & 15.0 & 1.4 & 14.6 & 23.5 & 19.4 & 2.2 & 14.0 & 22.2 & 18.4 & 2.4 \\
\hline Wet season & 10.3 & 15.9 & 13.2 & 1.3 & 10.3 & 13.9 & 11.7 & 1.1 & 10.7 & 14.5 & 12.9 & 1.1 & 10.9 & 15.7 & 13.5 & 1.2 \\
\hline Dry season & 3.3 & 5.7 & 4.3 & 0.5 & 4.0 & 4.7 & 4.3 & 0.2 & 3.7 & 4.5 & 4.1 & 0.2 & 3.6 & 4.6 & 4.1 & 0.2 \\
\hline \multicolumn{17}{|c|}{ Groundwater runoff } \\
\hline Annual & 3.6 & 10.2 & 6.1 & 1.5 & 4.8 & 10.2 & 6.8 & 1.3 & 4.2 & 7.9 & 5.4 & 0.6 & 3.7 & 8.3 & 5.2 & 1.2 \\
\hline Wet season & 2.7 & 7.0 & 4.5 & 1.0 & 3.4 & 7.0 & 4.7 & 0.9 & 3.2 & 5.3 & 4.1 & 0.4 & 2.8 & 5.6 & 4.0 & 0.7 \\
\hline Dry season & 0.8 & 3.1 & 1.6 & 0.5 & 1.3 & 3.1 & 2.0 & 0.5 & 1.0 & 2.5 & 1.3 & 0.3 & 0.8 & 2.5 & 1.2 & 0.4 \\
\hline \multicolumn{17}{|c|}{ Surface runoff } \\
\hline Annual & 5.0 & 19.1 & 11.4 & 2.4 & 5.5 & 12.3 & 9.3 & 1.8 & 7.9 & 15.9 & 11.6 & 1.2 & 7.7 & 14.9 & 12.3 & 1.8 \\
\hline Wet season & 2.4 & 14.5 & 8.8 & 2.6 & 2.4 & 10.0 & 5.7 & 1.7 & 4.7 & 14.0 & 10.8 & 1.7 & 4.1 & 12.9 & 10.3 & 1.7 \\
\hline Dry season & 1.7 & 4.6 & 2.7 & 0.5 & 1.7 & 2.9 & 2.4 & 0.3 & 2.2 & 2.9 & 2.7 & 0.1 & 2.1 & 3.2 & 2.8 & 0.2 \\
\hline \multirow{2}{*}{ Season } & \multicolumn{5}{|c|}{ Ouachita Mountains } & \multicolumn{6}{|c|}{ Mississippi Alluvial Plain } & \multicolumn{5}{|c|}{ West Gulf Coastal Plain } \\
\hline & Min & & Max & Mean & Std dev & & Min & Max & Mean & Std dev & & Min & Max & Mean & & Std dev \\
\hline \multicolumn{17}{|c|}{ Precipitation } \\
\hline Annual & 42.3 & & 4.7 & 53.0 & 3.2 & & 46.1 & 55.2 & 49.9 & 1.8 & & 47.5 & 54.3 & 51.4 & & 1.4 \\
\hline Wet season & 22.9 & & 4.1 & 28.1 & 1.7 & & 25.4 & 31.3 & 28.3 & 1.4 & & 24.6 & 30.6 & 28.1 & & 1.1 \\
\hline Dry season & 21.7 & & 1.2 & 24.9 & 1.7 & & 19.7 & 23.9 & 21.6 & 0.6 & & 21.3 & 25.0 & 23.3 & & 0.6 \\
\hline \multicolumn{17}{|c|}{ Total runoff } \\
\hline Annual & 14.6 & & 7.1 & 20.4 & 2.6 & & 14.7 & 22.0 & 17.5 & 1.5 & & 12.7 & 23.2 & 17.2 & & 2.1 \\
\hline Wet season & 12.6 & & 5.9 & 14.8 & 0.5 & & 10.8 & 13.9 & 12.6 & 0.8 & & 12.7 & 15.7 & 14.0 & & 0.8 \\
\hline Dry season & 3.6 & & 5.6 & 4.6 & 0.5 & & 3.3 & 5.1 & 4.3 & 0.4 & & 3.4 & 5.7 & 4.4 & & 0.7 \\
\hline \multicolumn{17}{|c|}{ Groundwater runoff } \\
\hline Annual & 3.6 & & 7.1 & 4.9 & 0.6 & & 5.1 & 10.0 & 7.5 & 1.1 & & 4.2 & 5.9 & 5.0 & & 0.3 \\
\hline Wet season & 2.7 & & 5.1 & 3.7 & 0.4 & & 3.9 & 7.0 & 5.6 & 0.7 & & 3.2 & 4.6 & 3.8 & & 0.2 \\
\hline Dry season & 0.9 & & 1.9 & 1.2 & 0.2 & & 1.0 & 3.0 & 2.0 & 0.4 & & 0.9 & 1.5 & 1.2 & & 0.1 \\
\hline \multicolumn{17}{|c|}{ Surface runoff } \\
\hline Annual & 10.3 & & 9.1 & 14.5 & 1.1 & & 5.0 & 12.4 & 9.4 & 1.2 & & 10.5 & 17.0 & 13.1 & & 1.5 \\
\hline Wet season & 8.1 & & 4.5 & 11.7 & 1.1 & & 2.9 & 13.4 & 7.5 & 2.0 & & 6.0 & 13.6 & 9.5 & & 1.2 \\
\hline Dry season & 2.4 & & 4.6 & 3.4 & 0.4 & & 1.8 & 2.7 & 2.3 & 0.2 & & 2.2 & 4.5 & 3.1 & & 0.6 \\
\hline
\end{tabular}


Table 4. Mean annual and monthly precipitation and runoff by physiographic sections in Arkansas, 1951-2011. [Units, inches; $\leftarrow$ Driest inches Wettest $\rightarrow$ ]

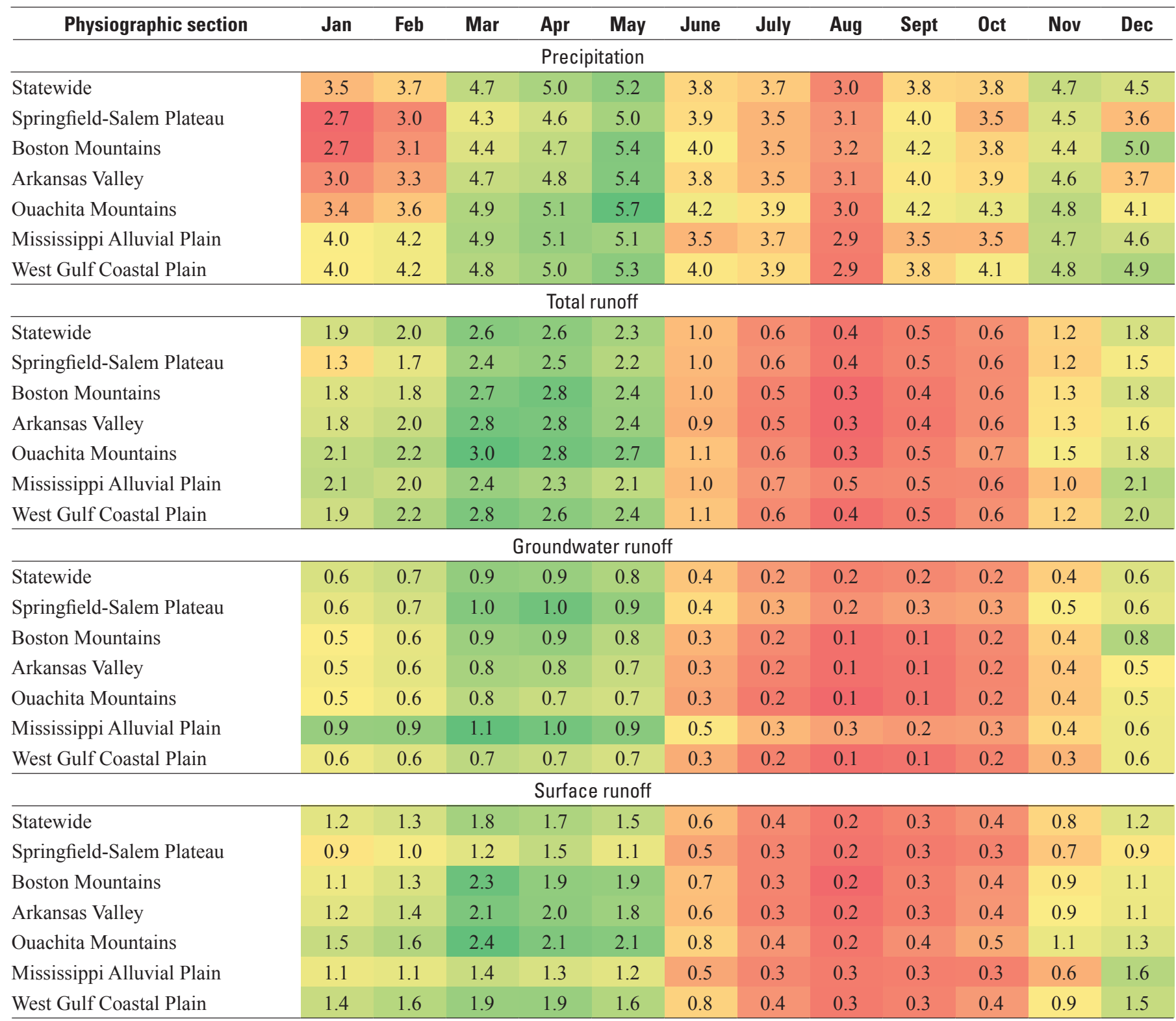


Table 5. Percentage of mean annual precipitation and runoff by month for physiographic sections in Arkansas, 1951-2011. [Units, percent; $\leftarrow$ Smallest $\quad$ percentage $\quad$ Largest $\rightarrow$ ]

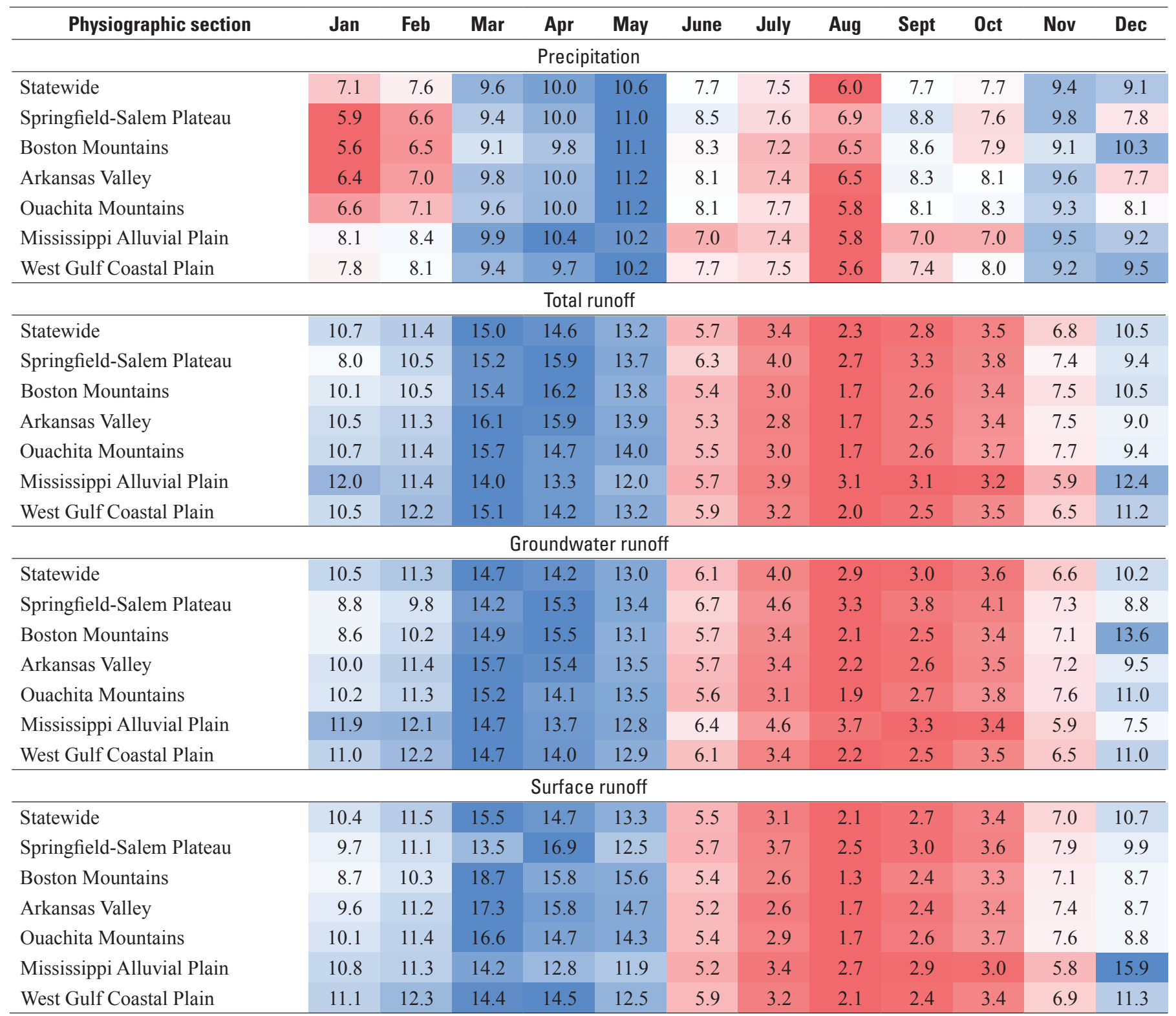


